\title{
The Role of Religion in a Catholic Law School: A Century of Experience at Loyola University Chicago
}

Thomas M. Haney

Loyola University Chicago, thaney@luc.edu

Follow this and additional works at: https://ecommons.luc.edu/social_justice

Part of the Law Commons

\section{Recommended Citation}

Haney, Thomas M., "The Role of Religion in a Catholic Law School: A Century of Experience at Loyola University Chicago" (2014). Social Justice. 14.

https://ecommons.luc.edu/social_justice/14

This is brought to you for free and open access by the Centers at Loyola eCommons. It has been accepted for inclusion in Social Justice by an authorized administrator of Loyola eCommons. For more information, please contactecommons@luc.edu. 
The Role of Religion in a Catholic Law School:

A Century of Experience at Loyola University Chicago

Thomas M. Haney

\section{Outline}

1. Introduction

2. 1908 to 1921: Educating an Urban Population

3. 1921 to 1937: Broadening the Horizon

4. 1937 to 1959: The Fitzgerald Years

5. 1959 to 1983: Transition and Growth

6. 1983 to 2004: The Appel Years

7. Into the New Century

8. Conclusion 


\title{
The Role of Religion in a Catholic Law School: A Century of Experience at Loyola University Chicago
}

\author{
Thomas M. Haney
}

\begin{abstract}
Many criteria have been suggested for identifying a Catholic law school and determining whether a law school claiming that identity is indeed truly Catholic. Many articles have been written which critique Catholic legal education in general and which judge whether catholic law schools as a whole, or individual Catholic law schools, meet the offered criteria for such identification. Most of those articles deal with only certain aspects of legal education at Catholic law schools.

The purpose of this article is to examine the record of one Catholic law school, the School of Law of Loyola University Chicago, which a few years ago celebrated its centennial. This is a detailed study of how the Catholic identity of Loyola Chicago's law school has manifested itself over the past century, during several distinct eras.

The article concludes that the criteria chosen to identify a truly Catholic law school will determine the result of whether any particular law school is indeed Catholic, and that different scholars and commentators will choose different criteria, therefore arriving at different conclusions. The article also concludes that, regardless of the criteria chosen, it is misleading to contend that the Catholic identity of Loyola Chicago's law school is non-existent or a mere veneer.
\end{abstract}




\title{
The Role of Religion in a Catholic Law School: A Century of Experience at Loyola University Chicago
}

\author{
Thomas M. Haney* \\ "The first law of history is to dread uttering a falsehood; the next is not \\ to fear stating the truth; lastly, the historian's writings should be open to \\ no suspicion of partiality or animosity." Pope Leo XIII
}

\section{INTRODUCTION}

The School of Law of Loyola University Chicago celebrated its centennial several years ago. During the past hundred years, that law school has educated women and men from many different faith traditions (and those of no faith tradition), races, ethnic backgrounds, sexual orientations, disabilities, and other characteristics. At the same time, it has accepted (and from time to time embraced) its heritage as a "Catholic law school" or as a "Jesuit Catholic law school"' - or at least as a law school which is an integral part of a Catholic university.

\footnotetext{
1 Letter of Pope Leo XIII to Josef Hergenrother, in connection with the opening of the Vatican Archives, where the quote is rendered in English as "The first law of history is not to dare to utter falsehood; the second, not to fear to tell the truth." John Jay Hughes, Vatican Archives: What's the Problem?, http://www. catholicculture.org/culture/library/view. cfm?recnum=4465

2 Beginning in July 1956, The Catholic Lawyer began publishing a series of articles on "Catholic Law Schools in America." Loyola was featured five years later: Vincent F. Vitullo, Loyola University School of Law - Chicago, 7 Cath. Law. 305 (1961). At no point in the article does the author refer to Loyola as a "Catholic law school," although its Catholic identity was understood by its inclusion in the series.

3 The phrase "Jesuit Catholic" is a current identifier for the university as a whole; e.g., the Faculty Handbook states "We are Chicago's Jesuit Catholic University" and it discusses "[o] ur Jesuit Catholic tradition of excellence." Loyola University of Chicago, Faculty Handbook, undated [approx. 2009-2010]. The law school's mission statement, adopted by the faculty in 2002, describes
} 
This article will explore how these identifiers, and the characteristics they represent, have been interpreted, applied and practiced at Loyola's law school over its first century of existence.

There is currently an ongoing discussion in legal academic circles about what it means to be a Catholic (or otherwise religious) law school. This discussion has prompted inquiries not only about what a "Catholic law school" is or might be or should be but also about whether some "Catholic law schools" have truly been or remain Catholic.

Throughout the academic debate and embedded in the historical record, it is possible to identify several attributes that, alone or in combination, might or should characterize a law school as a Catholic institution. ${ }^{4}$ Some of these factors are institutional:

- Affiliation with a Catholic university. ${ }^{5}$

- External indicia of Catholic identity such as crucifixes in classrooms. ${ }^{6}$

the school as follows: “Loyola University Chicago School of Law is a studentfocused law center inspired by the Jesuit tradition of academic excellence, intellectual openness, and service to others." Infra note 331.

${ }^{4}$ Philip J. Grib, Legal Education in Jesuit Universities (paper prepared for presentation at Georgetown University in June 1989), 2 et seq.

5 This was apparently the criterion selected by The Catholic Lawyer for its series on Catholic law schools, supra note 2 .

6 Not all agree with this, however. In answer to the question of what it means to be part of the Jesuit educational tradition, "[i]t should have little to do with crucifixes on classroom walls..." Steven M. Barkan, Jesuit 
- Ceremonies (such as Mass) and practices (such as retreats) that enable Catholic law students and faculty to practice their faith in the confines of the law school.

- Self-identification with the hierarchical structure of the Catholic Church. ${ }^{8}$

- Proclaiming a Catholic identity in publicity and marketing. ${ }^{9}$

Law Schools: Challenging the Mainstream, Conversations on Jesuit Higher Education (Spring 1993), 7, at 10-11.

7 "[A] vigorous spiritual life should be fostered in a truly Catholic law school." Leonard J. Nelson, III, God and Man in the Catholic Law School, 26 Catholic Lawyer 127 (1981), at 145. "[A] Catholic law school should make available on a regular basis the opportunity to participate in the sacraments, and other forms of religious worship and observance." Basile J. Uddo, Catholic Law Schools: A Modest Proposal for Uniqueness, Catholicism in Crisis (Apr. 1984), 34, at 35. Again, not all agree with this view. In answer to the question of what it means to be part of the Jesuit educational tradition, "[i]t should have little to do with ... law school liturgies...." Barkan, supra note 6, at 11. "The vestiges of Catholic identity that do remain are largely symbolic or ornamental in nature - the celebration of a Red Mass to begin the academic year, or the well-placed portrait of St. Thomas More in the school library." John M. Breen and Lee J. Strang, The Road Not Taken: Catholic Legal Education at the Middle of the Twentieth Century, 51 Amer.J.Leg.Hist. 553 (2011), at 555.

8 "[At one time, Catholic universities and law schools] were ... part of the cradle-to-grave network of institutions provided by the immigrant church for its people..." Mark A. Sargent, An Alternative to the Sectarian Vision: The Role of the Dean in an Inclusive Catholic Law School, 33 U. Tol. L. Rev. 171 (2001), at 188. "In the Catholic Church, the local Bishop is responsible for the Catholic-affiliated law schools within his particular diocese... [T] he integral role of the Bishop in the life of the Catholic law school is not negotiable." David L. Gregory, The Bishop's Role in the Catholic Law School, 11 Regent U.L.Rev. 23 (1999) at 25, 28.

9 "The first essential characteristic [of the inclusive Catholic law school] is that the school is unapologetic about its Catholic identity." Mark A. Sargent, We Hold These Truths: The Mission of a Catholic Law School, Commonweal (Apr. 25, 2003), 14, at 15. "[T] he way in which a school publicly characterizes itself and its role within a Jesuit university does not completely reflect the substance of how and the extent to which it adheres to Jesuit principles of education. ... Still, examination of how a Jesuit law school publicly characterizes its own image represents a beginning in ascertaining how a particular school relates to the principles of Jesuit education." Robert J. Araujo, S.J., Legal Education and Jesuit Universities: Mission and Ministry of the Society of Jesus?" 37 Loy.L.Rev. 245 (1991-92), at 249 . 
Some of the factors relate to the faculty:

- The presence of priests or other religious on the faculty or in other significant roles. ${ }^{10}$

- The administration of the school directed by Catholics or those willing to assume a comparable role. ${ }^{11}$

- A significant percentage of Catholics on the faculty. ${ }^{12}$

- A faculty composed of teachers, regardless of their faith affiliation (or lack of one), who seriously engage with the Catholic intellectual tradition or that otherwise support the religious identity of the $\operatorname{school}^{13}$.

10 "Catholic law schools should have their own chaplains or campus ministers." Uddo, supra note 7. Again, there are dissenting voices: In answer to the question of what it means to be part of the Jesuit educational tradition, "[i]t should have little to do with ... priests serving as teachers." Barkan, supra note 6 , at 11 .

11 "[The dean of a Catholic law school] must lead in initiating the discussion among the faculty and other constituencies ... about the nature and implications of Catholic identity ... tak[ing] place in an energetic and searching manner... [T] [Te dean is charged with articulating ... the law school's sense of itself as a Catholic institution... [T]he dean of a Catholic law school must be a force for inclusion." Sargent, supra note 8, at $173-4$.

12 "The Catholic law school must bring together a critical mass of Catholics. This goal does not conflict with the inclusive character of the institution. ... Nevertheless, without this "critical mass" ... it is hard to see how the institution can remain Catholic. ... '[H]iring toward mission' is not just legitimate, it is indispensable." Sargent, supra note 9, at 16 . In answer to the question of what it means to be part of the Jesuit educational tradition, "[i]t need not mean ... that students and faculty are predominantly Catholic, although there should be enough Catholics among the students and faculty to represent the tradition." Barkan, supra note 6, at 10 .

13 Included in the answer to the question of what does it mean to be Catholic in the context of a law school is "a critical mass of dedicated Catholics supported by those who share the basic assumption that religion is a legitimate part of human experience that deserves respect." Uddo, supra note 7. "In order to preserve its Catholic tradition, ... faculty should be selected because of their commitment to the goals of the institution." Nelson, supra note 7, at 145. "If the mission of a Jesuit law school is indeed the promotion of justice ... then plainly the school must have faculty 
Some of the factors relate to students:

- A significant percentage of Catholics among the students. ${ }^{14}$

- Selection of students based on their faith or at least

their commitment to the goals of a faith-based

institution. ${ }^{15}$

- Enhancing the personal qualities of the students. ${ }^{16}$

Some of the factors pertain to the curriculum:

- Educating non-Catholics in the school about the Catholic religion. ${ }^{17}$

- Classroom attention to Catholic doctrine (mandatory or optional, pervasive or ad hoc). ${ }^{18}$

who are willing to take up this mission, embrace it, and carry it forward... $[\mathrm{T}] \mathrm{O}$ be a true colleague requires genuine collaboration in support of the mission, not passive indifference, let alone veiled or open hostility." John M. Breen, Justice and Jesuit Legal Education: A Critique, 36 Loy.U.L.J. 383 (2005), at 413-414.

14 “It need not mean ... that students and faculty are predominantly Catholic, although there should be enough Catholics among the students and faculty to represent the tradition." Barkan, supra note 6, at 10.

15 "In order to preserve its Catholic tradition, students ... should be selected because of their commitment to the goals of the institution." Nelson, supra note 7 , at 145 .

16 "The Catholic student... will find in the tenets of that faith the foundation of his legal knowledge... He will thus prove himself a more loyal Catholic, make himself a more useful citizen, and train himself to be a more capable lawyer." Linus A. Lilly, S.J., The Catholic Law School, XV America 553 (September 16, 1916), at 554.

17 "It should be the aim of the Catholic student and, to some extent, the office of the law school under Catholic control, to send [young men of other creeds or of no creed] back to their homes with their prejudices removed, and their false impressions [of Catholicism] corrected ... giving non-Catholic law students broader and more liberal notions of Catholic doctrine and Catholic interests." Lilly, id.

18 "Certainly all Catholic law professors must actively oppose abortion in the classroom, while all non-Catholic law professors possess the duty to communicate the Church's position as an act of respect to the Catholic position." Daniel Gordon, Ex Corde Ecclesiae: The Conflict Created for 
- Teaching the law of the Roman Catholic Church. ${ }^{19}$

- Inclusion of religious-oriented courses in the regular

curriculum. ${ }^{20}$

- Special attention to the course on legal ethics. ${ }^{21}$

- Inclusion of faith perspectives on legal ethics and on lawyering. ${ }^{22}$

- A rigorous and sustained examination of justice. ${ }^{23}$

- Inclusion of a course in legal philosophy. ${ }^{24}$

American Catholic Law Schools, 34 Gonz. L. Rev. 125 (1999), at 145. Not all agree. "Jesuit identity is not found in the proclamation of a received truth. ... Jesuit law schools today must find a way to fulfill their mission amongst the multiplicity of faith commitments of students, faculty and staff." Andrew F. Moore, Contact and Concepts: Educating Students at Jesuit Law Schools, 41 Gonz. L. Rev. 459 (2006), at 480.

19 "[T]he legislation of the church will certainly find no place in the curriculum of any but a Catholic law school... . The Catholic lawyer must know his own ecclesiastical law... What place then has the Catholic law school in the educational system? Where else can he be expected to learn ... the law of his Church?" Francis J. Shalloe, S.J., Why Catholic Law Schools?, XLV America 233 (June 13, 1931), at 234.

20 "A serious effort should be made to develop courses that reflect Catholic and other religious perspectives." Sargent, supra note 9, at 16.

21 "One thing a Catholic law school should excell (sic) in is the teaching of professional ethics/responsibility." Uddo, supra note 7, at 35.

22 "[T] he required professional responsibility curriculum can become an opportunity ... to explore the surprising-for-some suggestion that it may be legitimate to bring one's own religious perspective to bear on professional decision-making, counseling, and judgment. ... Several law schools further the conversation about the extent to which religious values may inform a lawyer'a approach to the profession and the practice in the context of specialized seminars in 'religious lawyering'." Amelia J. Uelmen, An Explicit Connection between Faith and Justice in Catholic Legal Education: Why Rock the Boat?, 81 U. Det.Mercy L. Rev. 921 (2004), at 931, 933.

23 "... [I]f the true mission of a Jesuit law school is the promotion of justice, then the exploration of the meaning of justice must reach down into the heart of the academic enterprise, into the intellectual work of the institution. That is, the curriculum of a Jesuit law school must require students to engage in a rigorous, sustained examination of the subject." Breen, supra note 13, at 401 .

24 "Catholic law schools should teach legal philosophy, better know as jurisprudence. Such a course should be comprehensive in its approach, but with a decided bias toward Catholic/Christian concepts of jurisprudence, 
- Incorporation of natural law and/or Thomistic philosophy into law school education. ${ }^{25}$

- Engagement with Catholic social teaching and/or the Catholic intellectual tradition. ${ }^{26}$

- Encouraging discussion of religious values about the law. ${ }^{27}$

Yet other factors have to do with concrete expressions of

Catholic social and moral concerns:

- Establishment and support of programs that demonstrate attention to Catholic social thought and/or the preferential option for the poor. ${ }^{28}$

specially natural law in all of its historical and more recent permutations." Uddo, supra note 7 .

25 "[I]nstruction in Christian ethics and natural law, which are and must ever be the only sound foundation of his legal studies. ... [L]aw and authority are from God, and ... human enactments and regulations derive their force from the eternal law which the Author of nature has written in the hearts of men." Lilly, supra note 16. A movement arose in the $1930 \mathrm{~s}$ and $1940 \mathrm{~s}$ to have Catholic law schools provide their students with a thorough introduction to the Thomistic understanding of the natural law; the proposal, however, was never fully realized at any school. Breen and Strang, supra note 7, at 617 et seq. See infra note 106. A natural law perspective remains a goal for many: "First, [a truly Catholic law school] should offer a curriculum that is distinctively Catholic. It should seek not only to offer Jurisprudence courses emphasizing natural law, but also should bring a Catholic perspective to all positive-law courses. This could be effectuated by utilizing natural law concepts in positive-law courses." Nelson, supra note 7, at 145.

26 "[M] any Catholic law schools offer seminars in Catholic Social Thought and the Law, perhaps one of the best ways to help students to focus on the intellectual component, ... and to discuss the implications for practice." Uelmen, supra note 22, at 934. "[T]he Jesuit and Catholic identity, in the form of the Catholic intellectual tradition, must be found in the classroom and in what is taught [at Jesuit law schools]." Moore, supra note 18, at 468. "This [Jesuit] mission challenges us to expose our students in a more systematic way to the questions that the Catholic intellectual tradition poses to the often unexamined assumptions about what it is to be a human person that underlie much of American law." Gregory A. Kalscheur, S.J., The Law School Must Embody a Special Culture, Conversations on Jesuit Higher Education (Spring 2009) 21, at 22 .

27 "[T] he Catholic law school must create a space for religious discourse about the law." Sargent, supra note 9, at 16. 
- A focus on issues of justice. ${ }^{29}$

- Recognition of the dignity of each person (cura personalis). ${ }^{30}$

- Extracurricular and co-curricular organizations and activities that promote Catholic values. ${ }^{31}$

28 "That commitment to human dignity requires that a Catholic law school devote substantial resources to clinical legal education and pro-bono service for the poor. We have an obligation to instill in our students - Catholic and non-Catholic alike - an awareness of their ethical and spiritual obligation of lawyers to serve the poor. The Catholic law school must commit to such service precisely because it is Catholic." Sargent, supra note 9, at 16. "Jesuit legal education must promote a special concern, or a "preferential option,' for the poor and disadvantaged." Barkan, supra note 6, at 13. There must be "an explicit connection between the issue of justice in Jesuit legal education and what may be the most powerful learning experience in legal education: direct service to the poor and underserved. ... What is missing [and needed] is an integration of contact with concepts." Moore, supra note 18, at 470. "The provision of legal services to the poor and disadvantaged undoubtedly makes a valuable contribution to a school's Jesuit identity. At the same time, however, such a contribution constitutes at best only a partial and incomplete attempt to satisfy the Jesuit demand for the promotion of justice." Breen, supra note 13, at 395.

29 "Most importantly, a truly Catholic law school must have a commitment to justice... The commitment to justice, inspired by faith, should permeate the entire curriculum of a truly Catholic law school. The school should seek to graduate ministers of justice who will bring healing to a broken world." Nelson, supra note 7, at 146. "Catholic law schools should aim to provide students with at least the opportunity to reflect on how faith traditions might provide a robust and profound intellectual and cultural resource which can inform commitments to justice while working in any career..." Uelmen, supra note 22, at 923. The emphasis on justice is a hallmark of Jesuit education: "In modern times, the mission of the Jesuits and their institutions has become articulated as the "service of faith and the promotion of justice.'" Moore, supra note 18, at 462.

30 "Catholic legal education should be person-centered and dignifying." Uddo, supra note 7, at 36. "[T] he dignity of the individual must be given the highest priority. Each man and woman is personally known and loved by God, and the human effects of every encounter and transaction must be considered and evaluated." Barkan, supra note 6, at 13. "The Ignatian ideal of cura personalis is translated into student-centered education. Jesuit graduate education ... is student-centered with all the specificity that entails. Thus the increasing commitment to mentoring our graduate students." Charles L. Currie, S.J., Jesuit Graduate Professional Schools: Anything Distinctive?, Conversations on Jesuit Higher Education (Spring 2009), 2, at 5.

31 Some commentators question the centrality of this standard.

“Extracurricular groups such as St. Thomas More ..., although valuable, are all 
- Lectures, conferences and other academic programs that bring Catholic thinking and perspectives into the intellectual life of the law school. ${ }^{32}$

- Producing graduates who are "men and women for others."33

- A continual dialogue within the school on what it means to be Catholic. ${ }^{34}$

Not all of these factors are universally accepted, nor is the weight to be attached to each, nor is the ideal (or minimal) combination necessary for an institution to be truly catholic. Answers to these issues vary considerably among commentators. To a great extent, the debate as to what a Catholic law school

marginal to the essential educational processes and mission of a law school." Joseph P. Daoust, S.J., Legal Education in a Catholic University: Mission and Possibilities, 78 U. Det. Mercy L. Rev. 27 (2000), at 30 .

32 "A review of the websites of Catholic law schools for indications of a Catholic identity included a category of 'journals, institutes and frequent conferences whose purpose is to analyze the relationship between law and religion in general, or between law and Catholicism in particular.' While the majority of the law schools surveyed had no such item, there is no indication that these could not be valid indications of a catholic identity." John J. Fitzgerald, Today's Catholic Law Schools in Theory and Practice: Are We Preserving Our Identity?, 15 Notre Dame J.L. Ethics \& Pub. Pol'y 245 (2001), at 297 . 33 "Closely connecting faith with the promotion of justice leads Jesuit institutions to desire a particular outcome for their graduates. "Men and women for others' is the terms that emerged in the $1970 \mathrm{~s}$ to capture the aspiration for the educational apostolate." Moore, supra note 18, at 462-3. The phrase "man for others" was originally used by Pedro Arrupe, S.J., the Superior General of the Jesuits, in an address to the alumni of Jesuit schools and universities in Europe on July 31, 1973, in Valencia, Spain; the phrase was later broadened. Breen, supra note 13, at 387 .

34 "[T]he Catholic law school should be in a constant state of dialogue ... to refine continually what it means to be a Catholic law school." Uddo, supra note 7, at 36. "[A] Jesuit law school should be a culture of dialogue, diversity, and inclusion. [The Jesuit tradition] seeks to foster an environment in which a diverse community of people can learn from one another through speaking to one another and through listening to one another, in a dialogue that is open to, and respectful of, the experiences of all." Kalscheur, supra note 26, at 22-23. 
is or should be is reflective of a larger debate in American ${ }^{35}$ Catholic society: what is or should be the Catholic church, and what does it mean to be a Catholic?

The debate in American Catholic society has, in its simplest form, two sides ${ }^{36}$, both passionately devoted to defending, preserving and strengthening the Catholic Church. Yet, since each side has a different perspective on what the Church is or should be, their common goals are often overlooked in their vigorous advocacy of their own position.

The purpose of this article is not to answer the question of what a Catholic law school is, what the Catholic Church is, or what it means to be Catholic. The purpose is to examine one particular Catholic law school over its entire history to assess how it has conceived of itself as Catholic in different eras and to investigate the extent to which its Catholic identity has or has not manifested itself in the reality of its educational process.

There is no suggestion that Loyola's experience in this regard should offer any template or model for other religiousaffiliated law schools. The history of every law school has

\footnotetext{
35 While this debate is a global phenomenon, this article examines these issues exclusively in the context of the situation in the United states. 36 This characterization of two sides is obviously an oversimplification of a complex situation, but it is sufficiently true for the purpose of this article.
} 
followed a different trajectory, depending on its own unique circumstances - the impetus for its founding, the deans and faculty who have pursued its educational mission, the geographical and temporal setting in which it is located, and other factors. Nonetheless, the history of Loyola's law school is a significant part of the mosaic of what it means and has meant to be a Catholic law school in this country. 


\section{8 to 1921: Educating an urban population}

Loyola University Chicago began its existence as St. Ignatius College in 1870 when a Jesuit, Arnold Damen, S.J., opened its doors on the near west side of Chicago. Damen had been recruited in his native Holland by Peter DeSmet, S.J., to become a missionary in the United States. ${ }^{37}$ The energetic Damen came to Chicago in 1857 where he proceeded to establish a parish and build a church. ${ }^{38}$

With an "aggressive style of fund-raising," 39 he was eventually able to open the school. The building survived the Great Chicago Fire of 1871, one of the few structures spared from the general destruction despite its proximity to the origin of the fire, and the school continued to grow and develop. In common with other educational institutions of the day, the college offered an education ranging from junior high school through a bachelor's degree.

By the turn of the twentieth century, Chicago was a bustling, thriving city which had fully recovered from the fire. It had become the second city in the country in 1890 when its

\footnotetext{
37 Raymond J. Heisler, St. Ignatius College Prep: 125 Years of Jesuit Education 7 (1994). Ellen Skerrett, Born in Chicago: A History of Chicago's Jesuit University 88 (2008), at 2-32.

38 Heisler, supra note 37.

39 Id. at 8 .
} 
population exceeded a million. ${ }^{40}$ The population explosion was fueled by immigration, primarily from Europe, from the end of the Civil War and continuing until World War I. ${ }^{41}$

A large part of Damen's mission in Chicago had been to serve the Catholic population, consisting mostly of new Irish immigrants. They were eager for education, employment and social advancement. ${ }^{42}$ They had little opportunity for a quality legal education, however. The mostly working-class men were unable to afford either of the full-time law schools offered by universities, and the quality of the part-time schools was most questionable since law schools, like the legal profession, were essentially unregulated at that time. Besides, the worlds of

40 "[The population] doubled to over a million in 1890 (passing Philadelphia to become the "second city') and doubled again, to 2.2 million, by 1910." Demography: Chicago as a Modern World City, Encyclopedia of Chicago, http://www.encyclopedia.chicagohistory.org/pages/962.html. "The 1890s were an extraordinary decade for Chicago, perhaps the only period in the city's history when its status as a "world city" would be disputed by few... It is often said that Chicago grew more quickly in the second half of the 19th century than any large city in the modern history of the Western world. In the 1890s alone its population increased by 600,000. In 1900, with 1.7 million people, Chicago was, by some measures, (briefly) the fifth or sixth largest city in the world." The University of Chicago Library, Chicago in the 1890's, http://www.lib.uchicago.edu/e/su/maps/chil890/.

41 "When the flood of Irish, German and others inaugurated the third stage of American immigration history in the $1840 \mathrm{~s}$ and $1850 \mathrm{~s}$, Chicago was ready. This stage lasted until Congress closed the door in the 1920s. Thus Chicago's period of most rapid growth coincided about exactly with Europe's mass migration to the Americas." Demography, supra note 40. ${ }_{42}$ Nelson suggests that, as the American Catholic Church entered its secondgeneration stage, it encouraged and facilitated its members in the direction of upward social mobility, and that catholic colleges and universities stepped in to accommodate the consequent demand for professional education. Nelson, supra note 7, at 129-30. 
both legal education and legal practice were prejudiced against Catholics and others new to this country. ${ }^{43}$

The historical record provides no specific information as to what led five Chicago lawyers -- William Dillon, Michael V. Kannally, Judge Marcus Kavanagh, Patrick H. O'Donnell and Howard Sprogle, collectively referred to as "the founders" -- to their decision that there was need for a new law school in Chicago, one that would be Catholic in inspiration and affiliated with St. Ignatius College. Nor is it clear precisely when and how the five lawyers began to formulate their plans. Dillon, who would later become Loyola's first law school dean, had been born in the United States but had returned to Ireland with his parents. ${ }^{44}$ He was educated at private schools

\footnotetext{
43 “Bigotry and prejudice permeated the established bar and law school world. There clearly was egregious discrimination against African-Americans, Jews, Catholics, and immigrants from places other than Northern Europe." Susan K. Boyd, The ABA's First Section: Assuring a Qualified Bar (Section of Legal Education and Admissions to the Bar, American Bar Association, 1993), at 16. 44 Dillon's father, John Blake Dillon, had been a barrister, called to the Irish Bar in 1841, an age of active Irish nationalism. In 1848, a rebellion, led by the Young Irelander movement, took place, inspired by similar revolutionary movements across Europe and stoked by the Irish potato famine, both of which had recently begun. John Dillon was one of the founding members in the Young Irelander movement, although he had opposed the rebellion. He was nonetheless arrested as a Young Irelander leader, convicted of high treason, and sentenced to death. Queen Victoria later commuted the conspirators' death sentences. John Dillon, with others, was re-sentenced to exile in Van Diemen's Land (Tasmania). Before he could be exiled from Ireland, however, he effected an escape to France. From there he eventually made his way to the United States, where he was joined by his wife in 1849. William Dillon, born the next year, was apparently the product of their reunion. "William Dillon," 17 Chicago Bar Record 80 (1935); Thomas M. Haney, "Pioneering Spirit," Loy. Law, Fall 2008, at 24, 26. After receiving an amnesty, John Dillon returned to Ireland with his family in 1855 and was later elected to the British Parliament.
} 
and then at the Catholic University of Ireland, both in Dublin. The Catholic University had been established not long before by the Catholic bishops of Ireland to provide an alternative for the Queen's Colleges, which Catholic students were discouraged from attending. ${ }^{45}$ In 1854 John Henry (later Cardinal) Newman had been named its first Rector. At that time it had no charter from the state to confer recognized degrees, and its lectures were not recognized elsewhere in Ireland as leading to a degree. ${ }^{46}$

In late 1871, after university, Dillon moved to London, completed his law studies in the Middle Temple, and was called to the Bar. He then returned to Ireland where he received further legal education at King's Inn, Dublin, and where, in 1874, he was admitted to the Irish Bar. He remained a life member of both the English and the Irish Inns of Court. Dillon

\footnotetext{
45 When the Bill for the establishment of the Queen's College was introduced into the British Parliament in 1845, Daniel O'Connell, the Irish nationalist, opposed it: "Let the Protestants ... have the full use of Trinity College ... but for the purposes of Catholic instruction, let two more colleges be instituted, ... and let the Deans of those establishments be Catholic clergymen, whose appointment shall be vested in the Catholic bishop of the diocese." Fergal McGrath, S.J., Newman's University: Idea and Reality (London: Longmans, Green and Co., 1951), 44. Interestingly, John Dillon, with the leaders of the Young Ireland Party, had supported the Bill "on the grounds that higher education was an urgent necessity for the country, and that the united education of young men of different faiths would conduce to national unity." Id.

46 The issue of securing a government charter for the university was controversial and continued for some time. Id. at 483 et seq.
} 
practiced law in Dublin for about six years before his health failed.

In December 1879 he decided to return to the United States. He lived on a ranch in Colorado and later practiced law there for several years before moving to Chicago in 1893 intending to practice law. When the editorship of The New World, the official newspaper of the Catholic Archdiocese of Chicago, became vacant a few months after his arrival, however, he was appointed to that position by Archbishop Patrick Feehan. ${ }^{47}$ His eight and a half years as the editor presumably acquainted him with the full dimensions of the Catholic community in the city. He was apparently successful as an editor, although he had no prior journalism experience, but he eventually became interested in returning to the full-time practice of law. ${ }^{48}$

The founders presumably knew of other Catholic law schools that had been established, the majority by the Jesuits, mostly

47 Feehan had been born in Ireland in 1829; he came to America in 1852 and, when the diocese of Chicago was raised to an archdiocese in september 1880, he became its first archbishop. Feehan died in July 1902 -- the year that Dillon left the editorship of the New World. The New World on March 10, 1894, listed Dillon as the editor. In a "Special Announcement" about the change in editorial management, Dillon wrote, "The new editor bespeaks the indulgence of the readers ... and asks them to remember that a new editor ... cannot at once do all he would like to do." William Dillon, Special Announcement, The New World, Mar. 10, 1894, at 1.

48 "Mr. Dillon's law practice has reached such proportions that he found it hard to attend to both... During [the eight and a half years] his deep learning, good literary taste and sound judgment made him hosts of friends." Mr. Dillon's Resignation, The New World, Aug. 16, 1902. 
in urban areas (the notable exception being the non-Jesuit institution Notre Dame in South Bend, Indiana ${ }^{49}$ ). Both Sprogle and Kannally were graduates of St. Ignatius, and O'Donnell was a graduate of Georgetown. Likewise, the founders presumably were acquainted with the situation of the Catholic population, mostly of Irish origin, in Chicago. Four of them appear to have been of Irish descent and were presumably Catholic, although sprogle appears to have been neither. ${ }^{50}$

The first specific step on the road to the establishment of the school that the founders envisioned occurred on January 13, 1906, when they wrote to Henry J. Dumbach, S.J., the president of St. Ignatius college, to urge the creation of the law school that would eventually become the Loyola University Chicago School of Law. In part that letter stated:

We are of the opinion that a law school, conducted under the auspices of a Catholic college or university, and situated in Chicago, the great metropolis of the middle west, would succeed. At present there is a large number of Catholic young men to be found in the various law schools of the city, and the greater number of these, in all probability, would prefer to enter a law school under

\footnotetext{
49 Notre Dame's law school had been established in 1869. Edward F. Barrett, "The Notre Dame Experiment," 2 Cath.Law. 294 (1956), at 295.

50 sprogle listed himself as a $32^{\text {nd }}$ degree Mason and as a Shriner. 50 Chicago Legal News (December 27, 1917), 173.
} 
Catholic auspices, if such a one existed. Moreover a law school manned by an able faculty ... would be patronized, we think, by a number of non-Catholic students. ${ }^{51}$

As far as we know from the records, there was no explicit discussion about what a Catholic law school should be, or what would make a law school eligible to be considered Catholic. One fact is clear: from the outset, Loyola's new law school was not thought of specifically as a "Catholic law school." In the founders' initial letter to Dumbach, they spoke of their vision of "a law school, conducted under the auspices of a Catholic college or university." ${ }^{52}$ In similar language the new president of the college, Alexander Burrowes, S.J., soon endorsed the proposal for the "first law school to be conducted under Catholic auspices in Chicago." ${ }^{53}$ The principal movers of the project therefore seem to have conceived of the new school as primarily a law school, albeit one within the purview of a Catholic educational institution.

\footnotetext{
51 Letter from Wm. Dillon, P. H. O'Donnell, Judge Cavanaugh (sic), Howard Sprogle, \& M. Kannally, to Reverend Henry J. Dumbach, President, St. Ignatius College (Jan. 13, 1906) [hereinafter Letter from Founders to Dumbach].

52 Id.

53 Skerrett, supra note 37, at 88. Chicago's other Catholic law school, DePaul University College of Law, came into existence in 1915 when the university affiliated with the existing Illinois College of Law. Robert $Q$. Kelly, “DePaul University College of Law," 6 Cath. Law. 287 (1960).
} 
There was no expressed desire to establish a law school that taught Catholic doctrine, or that set out to make its students better Catholics, or even to teach a Catholic perspective on the law. Neither the faculty nor the student body were to be composed exclusively of Catholics, just as not all of the men involved in the founding and initial operation of the school were Catholic. Their goal was simply to establish a law school that would enable its students to enter the ranks of the middle class and to move up the social ladder beyond their mostly immigrant roots.

The Catholic identity of the school was nonetheless a paramount concern to the founders. It seems evident that the founders expected the "auspices of a Catholic college or university" to provide something more than a purely technical legal education -- otherwise they could have established a proprietary law school or sought a non-religious college or university affiliation. That unarticulated "something more" presumably included a concept of a law school that not just educated its students in the technical knowledge or skills imparted by all law schools, but also one which inculcated, directly or indirectly, a sense of ethics and values, given the founders' familiarity with Catholic education. 
Whether or not there had been informal discussions with the college prior to the sending of the letter, as is likely, is not known. The college administration was quickly persuaded, however, that a law school would fit nicely into its expansion plans. ${ }^{54}$ The organization of the law school was completed by the middle of 1908 .

St. Ignatius college had not yet finalized the process of becoming a university to accommodate its first professional school, so the new law school was not initially to be a formal part of that institution, although it was indirectly and unofficially under the auspices of St. Ignatius. The school would be called the Lincoln College of Law. ${ }^{55}$ Dillon was named dean of the law faculty, perhaps because he was the one who was willing to surrender at least a part of his law practice for the new opportunity

54 "Jesuit universities started law schools for reasons that were ultimately theological but were also manifestly sociological and political. ... The Jesuits, and other Catholic educators, felt that they could make important contributions to the law and to society. ... American Catholic colleges also started law schools because they sought recognition as true universities; graduate and professional schools were needed to claim this stature. ... \{They] started law schools in reaction to the significant levels of nativism and anti-Catholic prejudice that existed at the end of the nineteenth and the beginning of the twentieth centuries." Barkan, supra note 6, at 9. 55 This was said to be the first law school in the United States to be named after Abraham Lincoln. Arnold McMahon, The Lincoln College of Law, The St. Ignatius Collegian, July 1908, VII No. 4, at 2. The St. Ignatius/Loyola relationship to the new school was acknowledged; infra note 60 . 
Arnold Damen McMahon ${ }^{56}$, who had been involved in the organization of the new school, was named the secretary and registrar of the new school; he would later become its second dean. McMahon and Dillon were the only full-time faculty and administrators, although even Dillon continued to be involved in legal practice to some extent.

The law school began its existence as an evening school in an urban setting, designed for working-class men, most of whom would be from immigrant or first-generation American families, with a mostly adjunct faculty drawn from the practicing bar. ${ }^{57}$ There was no explicit mention in the promotional brochure or catalog of the school's Catholic identity, although that dimension of its identity was probably understood quite well, given the identification of its affiliation with st. Ignatius College. The religious nature of the law school did not have to be justified or explained in that era - the affiliation alone

\footnotetext{
56 Named for Arnold Damen, S.J., the founder of St. Ignatius College, where he got his undergraduate degree, McMahon had received his law degree from the Union College of Law. Law: Foreword, The Loyolan - 1924, at 86 . His obituary, which contains several errors, stated that he "received his law degree in 1904 from the Illinois College of Law which became the Loyola law school." A. J.[sic] McMahon, Former Loyola Law Dean, Dies, Chgo. Trib., Jun. 5, 1955, at 41 .

57 McMahon wrote: “It will be the aim of the Lincoln College of Law to afford to those who must support themselves while preparing for the profession an opportunity to obtain a thorough training in all branches of the law. To this end it has been determined to hold the class sessions in the evening [Monday through Thursday] from 6:30 to 9:00 p.m." McMahon, supra note 55, at 2-3. These were the characteristics of almost all Catholic law schools that opened in this era. Nelson, supra note 7, at 130.
} 
was sufficient for that. ${ }^{58}$ Nor need any thought be given to what Catholicism was. Its faith, traditions and practices were known and understood by all those in the Catholic community and by many outside it.

While the new Lincoln College of Law was beginning its educational program, st. Ignatius college was transforming itself into a university. In 1909, the trustees of the college reorganized the institution into Loyola University, spurred by the establishment of the law school as its first professional school.

At the time of the establishment of the new university, the Chicago Tribune carried a story entitled "New School To Be Liberal," with the sub-headline "Loyola University Faculty Open to Men of All Faiths." The story included the following amplification:

Both Catholic and non-Catholic educators will sit on the faculty of the new Loyola university...

... The Jesuit leaders are employing professors and instructors without regard to their church association and even take men who have no church affiliation whatever.

58 "At one time, of course, Catholic law schools did not have to spend much time worrying about what it means to be "Catholic,'" Sargent, supra note 9, at 14 . 
Experiments have been made at St. Ignatius college ... in the employment of non-Catholic instructors side by side with Catholics and there has been no friction. The university does not maintain a department for the training of the priesthood. It is purely an educational institution. ${ }^{59}$ Lincoln college of Law formally became the Loyola University Law Department in 1909 when the university was formed, a name that it retained until the 1920's, when it became the School of Law. ${ }^{60}$ The university connection was an important element of the new law school's identity. Its Bulletin boasted that:

the Department enjoys ... the distinction of being the only evening law school in Chicago maintained and supported by a University. Members of the learned profession ... are continually pointing out the desirability of having professional schools placed under the control of literary [sic] institutions... Worthy young men, whose circumstances do not permit them to give the entire day to the study of law, may here secure their professional training and

59 Chicago Tribune, oct. 19, 1909, p. 7.

60 Even the short 1908 promotional brochure for the Lincoln College of Law contained the sub-heading "Law Department, St. Ignatius College." Lincoln College of Law (undated, but 1908 from internal evidence), unpaged [1]. For two years thereafter, the catalog referred to "The Law Department of Loyola University, known as the Lincoln college of Law" for continuity. Loyola University, Catalogue 1909-1910, at 82; Loyola University, Law Announcement 1910-11, at 5 . 
receive their law degrees from a University of recognized standing. 61

At that time, most if not all of the "leading" universities eschewed part-time and/or evening programs, focusing their efforts at educating the elite who were destined to attain significant roles in society. At the other end of the spectrum, a wide variety of law schools operated (in an era before scrutiny and regulation by the profession) as stand-alone institutions, many of dubious quality. It was left to Catholic universities in urban settings to offer professional education to those unable to attend the "leading" universities full-time. The entire curriculum was required. There were no elective courses in law in the early years. The upper-level curriculum contained most basic law courses. Third year students were to take a "lecture course" in Legal Ethics, for a total of eight hours. There was nothing in the curriculum that was specifically Catholic in orientation. The only course that might have touched on matters which were sensitive to Catholic authorities, was "Persons and Domestic Relations," the

\footnotetext{
61 Loyola University, Catalogue 1909-1910, supra note 60, at 82-3.
} 
description of which specifically included divorce; ${ }^{62}$ at the time, this did not seem to be perceived as a significant issue. The teaching methodology was described in the early catalog as being within the province of the individual teacher, all of whom were "leading practitioners at the Chicago Bar" and were "chosen because of success in their special field."63 But, the catalog went on: "All of the professors have, however, adopted a system of instruction based on the principles of the Ratio

Studiorum."64 There is no explanation of that reference; it was apparently assumed that readers would recognize it as the traditional principles of Jesuit education. ${ }^{65}$ The catalog describes the process as threefold: an initial lecture by the professor (referred to as the praelectio, again without explanation), the student's study at home of the assigned material, and a recitation by the student in class, usually accompanied by an extensive quiz of the material and hypothetical problems. This description is reminiscent of the

62 See infra note 276 for the later concern about Catholic lawyers and divorce.

${ }^{63}$ Loyola University, Catalogue 1909-1910, supra note 60, at 83.

64 Id. (Boldface in original.)

65 The Ratio Studiorum has been the basis of Jesuit education since the early days of the order, although it has been adapted in its applications throughout the centuries. A Superior General of the Jesuits, Luis Martín, referred to its essence as being composed of two elements: "that activity be demanded of the students, and secondly, that insistence be placed on the genuine formation of the human faculties rather than on amassing and learning of facts." Quoted in Allan P. Farrell, S.J., The Jesuit Code of Liberal Education (Milwaukee: The Bruce Publ. Co., 1938), at 402 . 
Socratic method, which had become widespread in U.S. legal education by that date. ${ }^{66}$

This pedagogical understanding among the teachers, to the extent that it existed, may or may not have extended to the theoretical basis of the legal education they provided. There is no indication that there was any explicit attempt to inculcate natural law concepts into the teaching, although that perspective may have been conveyed in at least some classes, given the Catholic backgrounds of most of the faculty. There is some suggestion, however, that the casebook method of Langdell, with its positivist understanding of law, overwhelmed any academic influence that natural law (or "higher law") proponents at both Catholic and secular law schools may have had. ${ }^{67}$ The Loyola faculty were apparently using the casebook method, as indicated by the course books listed in the annual catalogs, although their use of that methodology may not indicate that the faculty subscribed to Langdell's philosophy.

The officially articulated aim of the law school was "to give its students a thorough training, both theoretical and

\footnotetext{
66 "By the beginning of the twentieth century, Christopher Columbus Langdell's 'case method' of instruction had begun to gain wide acceptance in the legal academy, including at Catholic law schools. ... [B]y the 1920s, nearly all Catholic law schools had adopted it as a method of instruction." Breen and Strang, supra note 7, at 585-6.

67 "[S] ome Catholics resisted the case law approach, claiming that it concealed the fallacy of legal positivism," Breen and Strang, id. at 585. Nelson, supra note 7, at 132-33.
} 
practical, in all branches of the law."68 This is an articulation of one of the themes that run through the school's history: the deliberate inclusion of both the theoretical and the practical aspects of legal study.

Consistent with the law school's origins as a component of a Catholic institution, law students had the option of taking a non-law elective course on "Logic, Philosophy and Sociology," offered by a Jesuit priest, Edward J. Gleeson, S.J. Gleeson had offered the course for six years before the opening of the law school, but it soon became primarily affiliated with that school.

The course was designed for "college graduates, advanced and special students and professional gentlemen," although “[o]ther gentlemen, though not college graduates nor law students, are admitted to the class if their tastes and previous attainments qualify them to profit by it."69 Gleeson offered his course on Friday evening from 6:30 to 9 p.m., a night on which no law classes were taught. A majority of the early law students elected to take this course, thus committing themselves to classes for five nights a week. ${ }^{70}$

\footnotetext{
68 Lincoln College of Law, supra note 60, unpaged [3].

69 Loyola University, Catalogue 1909-1910, supra note 60, at 90.

70 Loyola University of Chicago, The School of Law, Diamond Jubilee (May 1, 1984), at 4 (hereafter referred to "Diamond Jubilee"). 
Gleeson's course was fundamentally a philosophy course with a measure of sociology, all from a distinctly catholic perspective. The detailed outline of this course was printed each year in the law school catalog, even though in the first several years the regular law courses in the required curriculum were listed merely by name. Imbedded within the outline were references to Catholic doctrinal thought. For example, the version in the 1909-10 catalog includes such points as "Marriage, of divine institution; hence in its essentials, independent of civil authority" and "Properties [of marriage]: Unity and Indissolubility; hence divorce impossible by human authority." ${ }^{71}$

About 1913, the teaching of the course was assumed by Frederic Siedenburg, S.J. ${ }^{72}$ Within a few years Siedenburg was joined by Patrick A. Mullens, S.J., the university-appointed regent ${ }^{73}$ of the Law Department. During this period, the course broadened from Gleeson's lectures into a broad two-year sequence of sociology, with lectures on moral philosophy and legal ethics; the latter included the intriguing topic of "unnecessary multiplication of statutes." In the area of moral philosophy, a Catholic perspective was present, although not dominant. There

\footnotetext{
71 Loyola University, Catalogue 1909-1910, supra note 60, at 92. 2 See text after note 85 infra.

73 See text prior to note 80 infra regarding the role of regent in the law school.
} 
was a reference to "the eternal law" and natural law, "duties to God," and "unity and indissolubility of matrimony." The section on sociology included sections on "the labor question," "the agrarian problem," and "the woman problem."74

Before the end of the law school's first decade, the course was listed as two separate courses in logic and natural law, with the former offered in the fall and the latter in the spring. The courses were free for those enrolled in the law school; others paid $\$ 12$. Natural law was advertised as excellent preparation for economics, political and sociology as well as having "its own cultural value"; the catalog noted, "as an element in the training for the practice of the legal profession its importance is paramount." ${ }^{75}$ The listing of this course as a voluntary undertaking, not part of the regular law school curriculum, disappeared from the law school catalog around 1920. About that time Siedenburg had become regent of the Law Department and was soon establishing his own School of Sociology (later Social Work) within the university. ${ }^{76}$

\footnotetext{
74 Loyola University Department of Law (1914), at 114-7. (Grammar and punctuation in the original.) The content of "the woman problem" was noteworthy: "[W]oman's place in society - her present condition - Suffrage and reform. Woman in industry and domestic service. Higher, Vocational and co-education. Christianity and the exaltation of woman."

75 Loyola University Department of Law (1918-9), at 217.

76 Infra note 85 .
} 
Dillon retired in 1916 and returned to Colorado. McMahon, who had served as the school's secretary and registrar since it opened in 1908, was appointed acting dean by the president of the university, John B. Furay, S.J. McMahon was later named Dean, a position that he held until he left the faculty in 1925. During its first decade and a half, the law school was devoted to producing men who would be able to practice law competently and ethically. Its target audience remained men who worked full-time and took the initiative to study law in the evening to enhance themselves.

It was assumed that the school was a part of a Catholic university. There was, however, no reference to a Catholic identity of the law school specifically in any of the catalogs of this period. A majority of the faculty and students were presumably Catholic, but there is no record of any decision to discriminate against anyone (or even to favor Catholics, but this may be implied). The school administration appears to have focused its efforts exclusively on providing an appropriate legal education. ${ }^{77}$ There is no indication that the university

77 Referring to Catholic law schools around 1920, "[t] hese were Catholic law schools in the sense that Catholics went to them... Students in them were not learning about their faith; they were getting ahead. They were not studying Aquinas or Augustine or Pope Leo's encyclical on social justice; they were studying casebooks, just like everybody else. If these educational communities were religious, it was because they sometimes provided convenient religious services for their Catholic students and, occasionally, a chaplain 
expected the law school faculty or administration to do anything else. The optional philosophy/sociology course, constituting the only offering with a religious focus, was an initiative of the university administration.

The law school remained open during World War I, although enrollment fell off sharply, picking up again after the war ended.

At the end of this era, Loyola was doing what most Catholic law schools were doing at that time: "providing a vehicle of vertical mobility for the children of the late immigrants: the Irish, Italians, Poles, Slavs, and Eastern European Jews. They had evening divisions (a mark of low status among law schools, then and now). Their physical facilities were removed from their liberal-arts campuses; their libraries were minimal; most of their faculty were part-time." 78

There is no indication that the law school administration and faculty gave any prolonged thought to the Catholic dimension of the enterprise. The university affiliation was deemed a sufficient indication of the school's identity. As one writer expressed it, "[w]ith faculties and student bodies overwhelmingly Catholic, with a strong clerical presence, and

to talk to." Thomas L. Shaffer, The Catholic Tradition, 22 Valpo.U.L.R. 669 (1988), at 670 . ${ }^{78} \mathrm{Id}$. 
with a sense of separation from the larger social and academic mainstream that was ambivalent about - if not hostile to - a largely immigrant church, it was difficult not to feel

Catholic." ${ }^{79}$

79 Sargent, supra note 9, at 14. 


\section{1 to 1937: Broadening the Horizon}

The 1920's saw a remarkable transformation of the school: the establishment of a day division, an expanded full-time faculty, new facilities, a graduate studies program, and significant diversity in the student body. These developments related to the way in which the program of legal instruction was given, not to the content of that program. Many of the changes, at least initially, appear not to have come from the law school administration. They were apparently inspired by Siedenburg, who was appointed regent of the school by the university president in 1921.

Appointed by the president, the regent (who, like the president, was always a Jesuit priest) appeared to serve both as the conduit of information between the law school and the university and as the voice of the university president in law school processes to assure that general university policies were followed. Several Jesuits held the post in the early years. About 1916 Mullens, who co-taught the optional Logic, Philosophy and Sociology course with Siedenburg, assumed the regent position and held for about five years, until Siedenburg succeeded him in 1921.

Within the law school, it appears that the day-to-day operations were under the control of the dean; this extended to 
the curriculum, the selection of faculty (most of whom at that time were adjunct teachers), ${ }^{80}$ and the selection and retention of students. There is no indication that the role of the regent was resisted by the law school deans or that the regent attempted to intrude in matters beyond his competence. As to Siedenburg's being the inspiration for many of the important changes, the evidence is indirect. He certainly appears to have assumed a more vigorous role in the law school as regent than had his predecessors, most of whom appear as no more than names in the school's records. He is said to have "reorganized the School of Law."81 An earlier history of the law school asserts that after Siedenburg became regent in 1921 "he immediately instituted a series of crucial changes." ${ }^{82}$

The assumption has been that these policy changes were due to Siedenburg's initiative. McMahon had been in office since 1916, first as acting dean. Throughout this period there were

80 The actual hiring appeared to be a university prerogative, with the law school dean making recommendations to the university president. See infra, note 140 .

81 Mary C. Schiltz, "Frederic J. Siedenburg, S.J., Eclectic Educator," 7 Vitae Scholasticae 474 (1988).

82 Diamond Jubilee, supra note 71, at 4. This brochure was published anonymously. The text was largely taken from another anonymous brochure prepared for the law school's 50th anniversary celebration: The Loyola University School of Law - An Historical Sketch, in The Loyola University School of Law 50 Anniversary Dinner (Apr. 29, 1958), at 4 (unpaged). According to the law student newspaper, Blackacre, the 1958 brochure had been written by Dean John C. Hayes and the 1984 brochure by Dean Charles R. Purcell. 75 Years of Excellence: Historical View, Blackacre (Loy. U. Chi. Sch. of Law, Chi., Ill.), April 30, 1984, Supp. at 5. 
no changes in the school's format of a single evening division with an all-male student body that had prevailed from its founding.

Siedenburg had begun teaching at St. Ignatius College in 1900, although he soon left to study economics and sociology in Berlin, Innsbruck and Vienna before returning to Chicago. While in Europe, he was influenced by progressive European social reformers, "whose ideas on social justice greatly influenced Pope Leo XIII when he came to write the social encyclicals of the late nineteenth century." ${ }^{83}$

Upon Siedenburg's return to Loyola in 1911, he established a Loyola Lecture Bureau in which prominent Catholics lectured on public issues of the day, an early experiment in applying Catholic social teaching to current problems. In the first year, over one hundred lectures were given. ${ }^{84}$

In 1914 he established a School of Sociology in the Ashland Block, a building in Chicago's downtown that also housed the law school; this has been recognized as the first Catholic school of social work in the U.S. ${ }^{85}$ He soon assumed control of the course

\footnotetext{
83 Schiltz, supra note 81, at 469. The social encyclicals included primarily Rerum Novarum (1891).

84 L. Frederick Happel, "Rev. Frederic Siedenburg, S.J.," 13 The Loyola University Magazine, no. 3 (March 1914), 11.

85 Robert C. Hartnett, S.J., "The Siedenburg Years: A History," Loyola Today (Spring 1978), 10 .
} 
on Logic, Philosophy and Sociology and began to shape it to reflect his own philosophy and approach.

While Siedenburg's focus was on social problems, an area in which he achieved lasting recognition, he received another opportunity to put his beliefs into practice when he was appointed regent of the law school. Under his inspiration, the law school was transformed in the decade of the 1920's by a remarkable diversification in the student body. The broadening of admissions standards appears to have begun almost immediately upon his assumption of the regent position. For the first time, the law school appeared to embrace ethnic, religious and gender diversity, although the presence of Hispanic and other ethnic names in the student body in the earlier decade indicates that there had been some modest measure of diversity from the school's establishment. Evidence suggests that this development was not passive, merely accepting those who applied, but actively reaching out to attract more diverse students. ${ }^{86}$ Women were welcomed and perhaps encouraged to enroll. Referring specifically to Siedenburg's role at Loyola's School

${ }^{86}$ There exists in the archives what appears to be a print advertisement for the university, prominently beginning with the law school. In addition to the usual format, the ad also appears in Hebrew, apparently designed for publication in a local Jewish newspaper. While there is nothing in the ad itself to suggest that it came from Siedenburg, directly or indirectly, its date (September 20, 1921) represents a period when he was influential in redirecting the university's focus. It represents a remarkable outreach to a community beyond its Catholic base. 
of Social Work (which grew out of his School of Sociology) but equally applicable to his influence at the law school, it was said that "Father Siedenburg was the first dean to admit women to Loyola. For a Jesuit school this was a major, quite radical departure from the 350-year-old tradition of admitting only male students to Jesuit schools." ${ }^{87}$

A key feature of Siedenburg's perspective was the role of Catholic social thought in the university. "He was a pioneer in the war on poverty and for social justice." 88 What was said of his School of Social Work can be said of the law school as well: while the academic program of the school must be premised in Catholic thought, thus attracting Catholics to the program, students of all faiths were welcomed; "some of its [the School of Social Work's] staunchest students have been Jews and Protestants." 89 "He was a forerunner of ecumenism. Protestant and Jewish fellow-citizens sought his counsel." 90

The full-time law faculty, originally consisting of only Dillon and McMahon, soon began to grow. John V. McCormick ${ }^{91}$, who

\footnotetext{
87 Schiltz, supra note 81, at 475, citing Robert V. Paskey, “History of School of Social Work at Loyola" (Ph.D. diss., Fordham University, 1985).

${ }^{88}$ Hartnet, supra note 85 .

89 Schiltz, supra note 81, at 474, quoting Marie Sheahan, "A Catholic School of Sociology," Catholic Charities Review 5 (June 1921), 196.

90 Hartnett, supra note 85.

91 McCormick's relationship with Loyola was recalled in In Memoriam: Judge John V. McCormick, 3 Loy.U.Chi. L.J. ix (1972).
} 
would soon become the third dean, Francis J. Rooney ${ }^{92}$, who would later be the bulwark of the faculty during World War II, and Sherman Steele ${ }^{93}$, who would teach for almost two decades, were all hired about 1924. The bulk of the curriculum continued to be taught by part-time faculty, several of whom assumed active roles in the school, even attending faculty meetings. ${ }^{94}$ It is unclear the extent to which the faculty engaged with Siedenburg; their task was to provide the professional instruction ${ }^{95}$, with broader matters generally being left to the dean, the regent and the university.

After the law school was admitted to membership in the Association of American Law Schools in December 1924, the American Bar Association placed it on its list of approved law schools the following March. One perennially contentious issue for the ABA had been the status of "mixed" or dual-division law schools -- those which offered both full-time and part-time legal education. The ABA had legitimate concerns about the

92 Rooney, Law Librarian and Educator, Dies, Chgo. Tribune (Oct. 1, 1968), at B10.

93 "Poor health" led to his retirement in 1942. Sherman Steele Retires, Loyola Alumni News (June 1942), unpaged [2]. Obituaries: Sherman Steele, Chgo. Tribune (Apr. 19, 1945), at 20.

94 "The Elward Family: Anchors of the Adjunct Faculty," in Thomas M. Haney, The First 100 Years: The Centennial History of Loyola University Chicago School of Law (2009), at 34. The participation of part-time teachers in faculty meetings is confirmed in the regular notes of faculty meetings; infra note 105 .

95 "Through the early years of their existence, Catholic law schools worked on developing programs that met accreditation requirements and garnered respect in mainstream legal education." Moore, supra note 18, at 468. 
quality of some evening law schools, although many ABA members demonstrated an elitist conviction that would preclude from law school those individuals who needed to hold full-time employment. ${ }^{96}$ These ongoing ABA discussions continued to implicate Loyola and other Jesuit law schools since the Jesuits had been aggressive in establishing urban law schools with evening divisions to accommodate working-class students.

The first ABA list of approved law schools in 1923 had included 39 schools, all of which were full-time single-division schools. In 1924 six additional law schools were approved; of this group, three were part of Catholic universities (all Jesuit sponsored): Creighton, Georgetown and St. Louis. The 1925 list comprised 14 additional law schools. In this group were five more Catholic institutions, including two with Jesuit affiliations: Loyola University of Chicago and Marquette. ${ }^{97}$

By the spring of 1926, the ABA and AALS had been able to sort out their differing approaches to the supervision of law schools, and in that year they produced a list of 62 law schools, all of which met the standards of both organizations. Of that group, 56 were "high-entrance, full-time" schools, and

\footnotetext{
96 Boyd, supra note 43, at 21-27. See also Barkan, supra note 6, at 10 . 97 ABA-Approved Law Schools and Year of Approval, in Boyd, supra note 43, at 139. The three other Catholic law schools included that year were Catholic University, DePaul and Notre Dame.
} 
six were "mixed" schools with separate full-time and part-time divisions; among the latter was Loyola University Chicago. ${ }^{98}$

McMahon resigned to enter the practice of law and was replaced in 1925 by McCormick. A graduate of the University of Wisconsin with a J.D. degree from the University of Chicago, McCormick had been in practice until he joined the Loyola faculty.

In the 1926-27 school year, the law school moved out of the Ashland Block and into another building in the downtown area of Chicago. The new quarters provided the school with the additional space that it needed. For the first time, the law school was no longer isolated from the rest of the university, for several other of the university's schools occupied space within the same building, providing education convenient for working individuals.

The small full-time faculty grew even more. McCormick recruited John Cushing Fitzgerald, a recent graduate of Harvard Law School, to join the full-time faculty of the law school in 1929. ${ }^{99}$ Fitzgerald would prove to be one of the most significant figures in the law school's history. ${ }^{100}$

\footnotetext{
98 Id. at 27.

99 A widely-told anecdote at Loyola's law school, with little verification, concerns Fitzgerald's coming to Chicago. After his graduation from Harvard, the dean informed him of an opening with a prominent law firm in New York and suggested that he apply for it, which he did. When he later reported to the
} 
The Great Depression reduced the enrollment in the law school, in particular the number of women students. Whether or not related to the Depression, the 1930's appeared to witness significant attention devoted to the law school's Catholic identity. That identity, not just in the law school but also in other professional schools within the university, was the subject of a discussion at a meeting in 1930 of the university's Council of Regents and Deans. While the ostensible topic of discussion was the question "What is the distinctive aim of the (sic) Loyola University?" the focus was really the professional schools: were they to give "a cultural or a professional education"? McCormick thought that "cultural training did not cease after the arts degree was obtained, but that there was a distinct place for Jesuit education and ideals in our professional schools." ${ }^{101}$ The discussion seemed to end inconclusively, with no indication as to how the subject would be pursued or the issue clarified.

$$
\text { In early } 1931 \text { the law school responded to a university }
$$
questionnaire "regarding Catholics and non-Catholics in

\footnotetext{
dean that he had been rejected for that position because he was Catholic, the dean promised him that he would refer the next job opening to him. The next one happened to be that of Loyola, seeking a new faculty member for its law school. The dean passed that opportunity to Fitzgerald, who applied for the position and was hired. For an abbreviated version of this story, see infra note 124 .

100 Infra, note 123.

101 October 1930 Meeting, Loyola University Council of Regents and Deans, p. 2.
} 


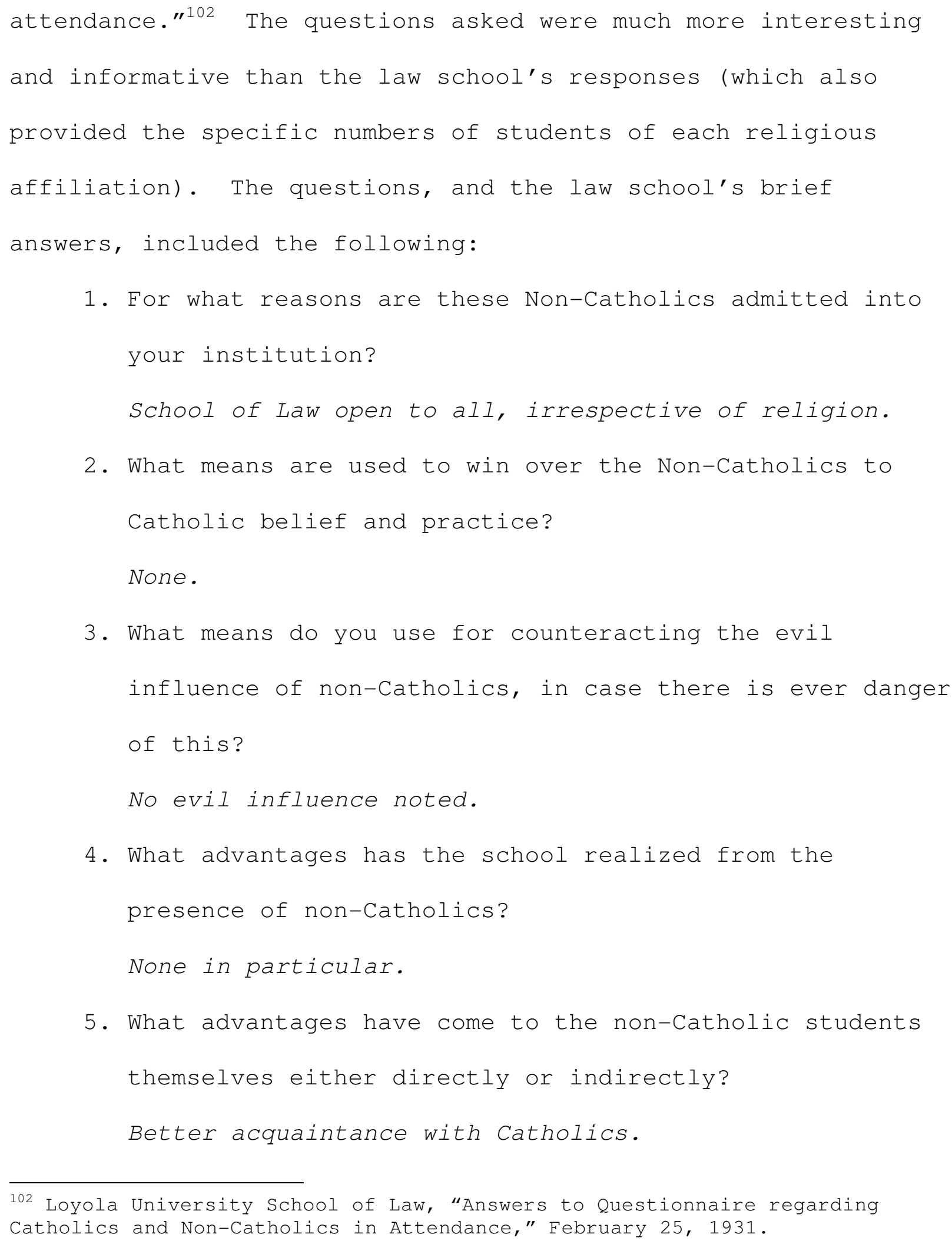

1. For what reasons are these Non-Catholics admitted into your institution?

School of Law open to all, irrespective of religion.

2. What means are used to win over the Non-Catholics to Catholic belief and practice?

None.

3. What means do you use for counteracting the evil influence of non-Catholics, in case there is ever danger of this?

No evil influence noted.

4. What advantages has the school realized from the presence of non-Catholics?

None in particular.

5. What advantages have come to the non-Catholic students themselves either directly or indirectly? Better acquaintance with Catholics.

102 Loyola University School of Law, "Answers to Questionnaire regarding Catholics and Non-Catholics in Attendance," February 25, 1931. 
6. How many conversions have been made?

None. ${ }^{103}$

Siedenburg stepped down as regent in 1932. His successors, including Thomas A. Egan, S.J., Dennis F. Burns, S.J. ${ }^{104}$ and John P. Noonan, S.J., attended faculty meetings, following the precedent set by Siedenburg. Noonan, a 1914 graduate of Loyola's law school, came to play an active role in the law school but seems to have been quite willing to defer to the dean, particularly when McCormick was replaced as dean by Fitzgerald in 1937 .

Perhaps as a follow-up to the university discussion of its schools' Catholic identity two years earlier, a similar discussion took place within the law school in 1932. "An informal discussion of the purposes and aims of the Catholic Law School took place, the theme being that we should put Catholic Philosophy into the law course where possible. It was pointed out that there was danger of law teaching becoming purely mechanistic."105 There does not appear to be any recorded

103 Id. The numbering of the questions has been somewhat altered from the original.

104 During the Burns years (1932-1935), as apparently in earlier decades, most communications between the university and the law school were conducted between the president and the regent, respectively; there is little evidence of the dean communicating directly with the president.

105 Minutes of Meeting of School of Law Faculty, October 26, 1932. Rooney had become the faculty secretary, and he took notes at all faculty meetings for the next decade. The minutes were typed and sent to the university president. 
follow-up to this discussion, but it does indicate that the administration and faculty of the law school were continually concerned with the school's Catholic identity, in addition to their ongoing efforts to provide a quality legal education. That the faculty continued to ponder these issues is confirmed by the law school's hosting the first meeting of the Committee on Philosophy of Law, a newly formed standing committee of the American Catholic Philosophical Association, in September 1935. Loyola was represented at this meeting by Fitzgerald and Noonan (now the regent). A graduate of Loyola's law school, James J. Kearney, who seems to have been passionately interested in Catholic philosophy being taught in Catholic law school, was also present. ${ }^{106}$

At the faculty meeting later that year, Noonan again raised the issue of the law school's Catholic identity. He "suggested that in some courses we could do a great deal to inculcate the proper philosophical tone. If there is anything in the text book that has reference to fundamental philosophy the correct principles should be taught. We have to teach the proper bases of ethics and politics. We have an obligation to protect

106 This initiative appears to have been relatively short-lived, primarily because of the lack of interest in its work displayed by faculty members at Catholic law schools. Grib, supra note 4, 6-12. See also infra note 122 . See infra note 135 for Kearney's subsequent involvement with the law. 
students from false philosophies."107 A general discussion

followed; according to the minutes of the meeting: "[I]t was

felt generally that while some of the law subjects lend

themselves more definitely to stressing the proper philosophical teaching, it is possible in all courses to guard the students

against the false tone lent by prognostic authors."108

In 1935, the dean of the University of San Francisco School of Law wrote to McCormick and Noonan proposing the formation of an Association of Catholic Law Schools. McCormick wrote to the new university president, Samuel K. Wilson, S.J., to explain their objections to such an organization. ${ }^{109}$ They acknowledged that Catholic law schools were mistrusted by and marginalized within the AALS, which at that time was the primary body overseeing U.S. law schools. They worried that the formation of such an organization might be seen as a step toward creating a voting bloc within the AALS ("a suspicion which is very readily engendered in the non-Catholic mind where Catholics are concerned"110) or might jeopardize the membership applications of other Catholic law schools which were then pending. They

\footnotetext{
107 Law Faculty Meeting, December 19, 1935, 2.

108 Id.

109 Letter from McCormick to Wilson, May 3, 1935. "A Catholic graduate of the University of Chicago law school ..., he [McCormick] understood the formidable challenges facing small Catholic law schools." Skerrett, supra note 37 , at 148,150 .

110 Id.
} 
proposed working within the AALS to make Catholic law schools and their officers more involved and accepted and "presenting the Catholic viewpoint"111 at AALS meetings.

The law school regents of several Jesuit universities attended the annual AALS convention later in 1935. Loyola was represented by its regent, Noonan. ${ }^{112}$ The small group of regents organized themselves into a formal body, and Noonan (one of two regents at the meeting who held a law degree) was elected its secretary. It is not clear if the deans of those schools also attended the AALS meeting; they were not present at the regents' meeting •

According to the minutes of this meeting, ${ }^{113}$ three items of interest concerned the regents. The first was making AALS inspectors understand "that Regents are intermediaries between the Presidents of our Universities and the various Deans and members of the Law Faculties."114 The second concerned Catholic Action in the law schools; "all agreed that, through the

\footnotetext{
111 Id.

112 "Father Noonan Dies," 3 Res Ipsa Loquitur, no. 1 (Feb., 1963), 18. Noonan was ordained as a priest in 1926, and served as regent of the law school from 1935 to 1941 .

113 Minutes of the Meeting of the Jesuit Law School Regents, held at Loyola University, New Orleans, Saturday, Dec. 28, 1935. 114 Id.
} 
teaching of Legal Ethics and Jurisprudence by the Regents, Catholic Action was being fostered quietly but effectively."115 Finally, in light of the fact that the majority of faculty members at the law schools represented by the regents at the meeting were Catholic, it was suggested that "an exclusive Catholic Faculty might not be approved" by the AALS "and might ultimately lead to our Law Schools being watched with supercritical eyes and ultimately voted out of" the AALS. ${ }^{116}$ The Loyola law faculty seems to have continued with having only Catholics on the full-time faculty although, with the exception of John C. Hayes, there were apparently no new full-time faculty hired during the Depression years.

Presumably this meeting of the regents represented a way for Catholic law schools to get together in the context of the AALS without the formation of a separate organization of those schools.

In 1936 Wilson, the university president, was notified that the Superior General of the Jesuit order had apparently become concerned about conditions existing in Jesuit professional schools in the United States and that an American Jesuit had begun an examination of them. Wilson alerted Noonan. "[Y] ou

115 Id. Most the regents at Loyola taught such courses; see infra at note 119 et seq.

116 Id. 
may know that Father $\mathrm{O}^{\prime}$ Connell is very much concerned about the lack of ethical teaching and religious influence in Jesuit professional schools throughout the country. [There was apparently no suggestion of any problem specifically at Loyola, however.] I am telling you this not by way of counsel or caution but because I am quite sure ... some very definite pronouncements will be made by the General relative to the religious tone of our professional schools and the religious life of our professional students."117

Throughout this entire period, the entire curriculum was required; there were no electives. The mix of courses changed slightly from year to year, however. ${ }^{118}$ A course in Natural Law was added to the regular curriculum perhaps as early as 1920 and continuing thereafter for several years, apparently taught by Mullens ${ }^{119}$; this was presumably a further development of the

117 Letter from Wilson to Noonan, May 16, 1936. The Superior General of the Jesuits at that time was Wlodimir Ledochowski, S.J. "Father O'Connell," whose identity apparently did not have to be explained to Noonan, was Rev. Daniel M. O'Connell, S.J., with whom Wilson maintained a vigorous correspondence.

118 The information on specific courses is taken from appropriate catalogs (sometimes called Bulletins) of the law school. It appears that they were dated prospectively, being used as recruiting publications, and their content reflected the curriculum of the previous academic year with a projection of what it was likely to be in the coming year. There is no assurance, therefore, that they reflect the actual curriculum that was offered in any particular year.

119 A Doctor of Law degree was conferred on Mullens by the law school in June 1920. Program of the Fiftieth Annual Commencement of Loyola University Chicago, June 12, 1920, unpaged [3]. There is no indication that the degree was honorary: it was not listed as Honoris Causa, as were other degrees conferred at that commencement, but there is also no indication in the record 
elective course in Logic, Philosophy and Sociology since it was offered only for evening division students, but now as a required course in their first year. At the same time, a course in Legal Ethics was required of all students, day and evening, in their final year.

By the mid-1920s, a combined course in Legal Ethics and Natural Law was listed, as a required upper-level course in both the day and evening division. The catalogs do not indicate who taught it, although siedenburg, still the regent, was also listed as a "professor of jurisprudence" so he was likely the teacher initially; later in the decade, the course was being taught by James F. Walsh, S.J., apparently not a lawyer. In the 1930-31 catalog, the course was scheduled to be taught in the day division by Siedenburg with Cornelius Palmer, a lawyer on the school's part-time faculty (although the 1931-32 catalog notes that the day division course was "omitted 1930-1931"); Walsh, now also the "Dean of Men" (a new position), taught the course with Palmer in the evening division.

After Siedenburg stepped down as regent in 1932, the course was taught by his immediate successor, Egan, with a lawyer, Charles Wylie Allen. Soon they taught the combined course only

of his study for or qualifications for this degree; catalogs at that time did not record the academic degrees of Jesuits, unlike other faculty members. 
in the day division, with Rev. Joseph Perkins, apparently a priest but not a Jesuit, taking Egan's place beginning about 1935. In the evening, Allen taught the course alone, but it was called only Legal Ethics.

Beginning with the 1933-34 catalog, a separate course in Jurisprudence entered the regular curriculum, required for first-year students in both divisions. (The ethics course remained an upper-level requirement.) It seems to have been taught initially by Egan, then by Perkins, then about 1935 by Noonan, the new regent. Noonan taught not only Jurisprudence in both divisions, but he also assumed the teaching responsibility for the Legal Ethics course in both divisions. Near the end of the decade, Noonan seemed to have restructured the Legal Ethics course, since it disappeared under that name, being replaced by a Jurisprudence II course, with Noonan teaching day and evening sections of that as well.

Throughout most of the 1930s, the various teachers used LeBuffe, Jurisprudence, ${ }^{120}$ as the required text for the courses

120 Francis P. LeBuffe, S.J., Jurisprudence (New York: Fordham Univ. Press, 1924). The book was said to summarize a "school of Pure Jurisprudence, the principles of which are interwoven in the very fabric of our American law." He explained that as follows: "As the historical inheritors of the English Common Law, we can trace our legal lineage back through the ecclesiastical chancellors of England, and thus find our Jurisprudence rooted in the doctrine of Natural Law and natural rights and consequently in an objective, real standard of justice." Preface, id. In the Preface to the Third Edition in 1938, as war in Europe loomed, he expanded his analysis: "[T]he philosophy [in the book] is not Catholic; and is not Catholic precisely because it is 
in both Jurisprudence and Legal Ethics. Noonan used what may have been the same book, Pure Jurisprudence, by the same author, for one year after he took over the course. For the next two years, Noonan apparently used only a personal selection of materials, since "instructor"s syllabus" was mentioned in the catalogs; he was presumably using this time to prepare his own book. Beginning in the late 1930s, Noonan began requiring his book, Principles of Law and Government ${ }^{121}$, which he used for both Jurisprudence I and II.

The history of this era indicates that a considerable effort was devoted to inculcating Catholic social teachings and the philosophical principles of natural law into the law school's administration and its curriculum. This emphasis continued and developed in the succeeding period. ${ }^{122}$

philosophy. It is, indeed, a philosophy traditional in the Catholic Church, but, being a philosophy - and not a theology - its premises and conclusions are wholly within the domain of reason." Francis P. Le Buffe, S.J., and James V. Hayes, Jurisprudence (New York: Fordham Univ. Press, 1938), V. 121 John P. Noonan, S.J., Principles of Law and Government (New York and Chicago: Mentzer, Bush and Co., 1936). In his Preface, Noonan noted that Le Buffe's book was then out of print; as a result, "there is no other one book in English ... which covers this field." Id., 4. (Emphasis in original.) Noonan outlined his perception of the material: "[T]he discussion of the subjects outlined in these pages is an absolute necessary foundation for a legal education. This is especially true at the present time since Pragmatism is almost universally taught in the law schools of our larger universities, and Materialism and Hegelian Evolutionary Pantheism are the only views regarded as tolerable by seventy per cent of our law school teachers." Id., 3-4.

122 Breen and Strang discuss in detail the efforts of some Catholic legal educators in this period to "build Catholic legal education around a rigorous study and exposition of the metaphysics and natural law theory of St. Thomas Aquinas" and "the tepid reception given to this proposal, and its eventual de 
McCormick resigned as dean in 1937 to become a judge. He had taught at the law school for over a dozen years (and would later return to the part-time faculty). As dean for most of that period, he had overseen the consolidation of the changes initiated by Siedenburg. Despite the diversification of the student body, the law school remained essentially a Catholic institution, with its Catholic identity the subject of ongoing internal interest and discussion. Fitzgerald was named Acting Dean to replace McCormick.

facto rejection by law schools affiliated with Catholic universities." Supra note 7, at 556. Although most of those law schools offered courses in legal philosophy and natural law, "jurisprudence was, at best, a subsidiary concern. The idea of presenting American law in a way that (with few exceptions) was consonant with the Catholic intellectual tradition was taken for granted..." Id. at 584. This analysis seems to undervalue that concern that Catholic legal educators, at least at Loyola, had for jurisprudence, although they recognized that their primary educational goal was to teach "secular" legal subjects. They did assume that their way of presenting American law was consonant with the Catholic intellectual tradition, and they seemed both to work at assuring that would be so and to be proud of their achievements. 


\section{TO 1959: The Fitzgerald Years}

John Cushing Fitzgerald would turn out to be a pivotal

figure who shaped the destiny of Loyola's law school throughout

the middle of the 20th century. His service at Loyola spanned thirty years in which he became dean and led the school through the turmoil of World War II and into the modern era. ${ }^{123}$ If there were ever an era in the law school history which could be considered the "golden age" of Catholic identity, Fitzgerald's deanship would be it. His entire deanship was devoted to making Loyola distinctively Catholic in every respect.

Born to an Irish Catholic family in Boston in 1903, he was educated in public schools in Cambridge, then earned his A.B. degree at Boston College, a Jesuit institution, in 1925. He received his LL.B. from Harvard in 1928 and joined the Loyola faculty later that year. ${ }^{124}$

123 "For all intents and purposes, he was the founder of this law school," said a later dean, Charles Purcell. "Former Law Dean Fitzgerald Dead at Age 88," Loyola Law (Spring 1992), 31.

124 Nelson, supra note 7, at 129. "[0]n finishing his law studies at Harvard in 1928, it was Dean Roscoe Pound who recommended him for a post on the faculty at Loyola." Thomas Carpenter, "John C. Fitzgerald," 1 Loyola Law Times, no. 1 (Nov. 1960), at 9. Harvard Law School had a history of hostility to graduates of Jesuit schools, based on their presumed inferior educational standards. "[I]n the late 1890s ... Harvard Law School's refusal to recognize the diplomas of Jesuit colleges ... shook Catholics out of their complacency [about their educational systems]." Kathleen A. Mahoney, Catholic Higher Education in Protestant America: The Jesuits and Harvard in the Age of the University, Baltimore and London: The Johns Hopkins University Press, 2003, at 6. Boston college was particularly affected by the exclusion, and it vigorously opposed it for decades. James o'Toole, Class Warfare, Boston College Magazine (Winter 2012),

http://bcm.bc.edu/issues/winter_2012/features/class-warfare.html -- 
An excellent and direct working relationship seems to have developed early between Fitzgerald as dean and Wilson as president, although they might not always agree. This was a noteworthy achievement, given that the law school regent had previously been the conduit of information between dean and president. Noonan seems to have been satisfied with this arrangement. At one point, Fitzgerald even recommended to Wilson that there was no longer a need for a full-time regent of the law school "if [the president and the university] have confidence in the dean."125 In a letter to Noonan, Wilson seemed to approve of Fitzgerald's suggestion: "Personally I am not so sure that your time should be taken up with these duties, for the obvious reasons that make the office of a regent suspect by professional groups." ${ }^{126}$ Nonetheless the position of regent appears to have continued for a while longer.

While Fitzgerald was still acting dean, the faculty devoted one of its meetings to a discussion of a very recent article by Max Radin, a professor of jurisprudence at the University of California; the article was "The Education of a Law Student" from the California Law Review ${ }^{127}$. While Noonan led the discussion, Fitzgerald appears to have been one of the principal

\footnotetext{
125 Letter from Wilson to Noonan, August 18, 1937. 126 Id.

12725 Cal.L.Rev. 676 (1937).
} 
speakers, with very firm ideas on the subject. "The purpose of discussing this article is that it indicates the trend of legal scholars ... [and] other law schools ... in the direction of natural law and suggests that the question of whether or not we are actively relating our curriculum and teaching to our common background. The article indicates also that there is no necessity for a Catholic law school unless it is operated upon Catholic philosophical principles. ... Many case books in use today are opposed in principle to the natural law..." ${ }^{128}$

Fitzgerald returned to a theme raised at a faculty meeting two years earlier"129: "I would suggest that we jot down conflicts between what the books teach and what the proper ethical judgment should be. [With up to one-third of the students not being Catholic or from non-Catholic pre-legal colleges,] [t]his gives us a greater responsibility to inculcate the correct moral principles of law and to warn against the ethical errors in the case books." ${ }^{130}$

Fitzgerald also raised an issue on the role of natural law, a topic to which he was to return frequently throughout his deanship. He proposed that the catalog "declare that this School teaches not only the common law and statutory law but

\footnotetext{
128 Law Faculty Meeting, Oct. 8, 1937, 1.

129 Supra note 107.

130 Law Faculty Meeting, Oct. 8, 1937, supra note 128, at 1-2. 
also the necessity for positive law to be based on the principles of the natural law -- that the course aims to give the student not only a technical knowledge of positive law content but a philosophy of law based on correct moral principles."131 The faculty accepted this suggestion. For decades the school's annual Bulletin had briefly discussed the case method of instruction, with the school's aim being "to give its students a thorough training, both theoretical and practical in all branches of the law ... which is indispensable to students in whatever jurisdiction they may intend to practice." ${ }^{132}$ In the 1938 Bulletin, with Fitzgerald now as acting dean, the Method of Instruction and Aim section was amplified to articulate a religious perspective, pursuant to the faculty vote the previous year:

The school, as a department of the University, aims at building the consciences of the students for the fulfillment of their civil, social, and religious duties. The faculty strives, wherever possible, to evaluate the positive law in relation to Neo-Scholastic principles of jurisprudence. ${ }^{133}$

\footnotetext{
131 Id.

132 Catalog 1909-1910, supra note 60, at 83.

133 Loyola University of Chicago, School of Law, Bulletin (July 1938), 10-11.
} 
This new focus was consistent with Wilson's own vision of the mission of Loyola's law school, which he articulated in the fall of 1937 addressing the incoming class of law students: You are not attending merely another law school of the two hundred or so that supply the demand for lawyers in the United states. You are attending ... a school integrated by certain fundamental principles that saw light with the dawn of the human race, a school in which the "rights of man" is not an empty phrase but a guiding standard, ... an animating principle of human conduct and a gauge for rules of human conduct. ... No matter what the course or class room you will find that the approach to problems of law in this school is based and centered upon the individual as the moral, philosophical, and economic unit and that your judgment is developed to draw the line at which the good of that unit is limited by the common good of all the members of the community. ... [H]ardly a voice is heard to proclaim the natural law background of our federal constitution. To read or discuss the federal constitution without acknowledging its natural law background is to devitalize 


$$
\begin{aligned}
& \text { its provisions and to make it merely the tool of a } \\
& \text { politically dominant group. }{ }^{134} \\
& \text { In early } 1937 \text {, James } \mathrm{J} \text {. Kearney, }{ }^{135} \text { an alumnus of the law }
\end{aligned}
$$

school and a part-time teacher there, wrote to Wilson promoting Chicago's having a Catholic Lawyer Guild as other cities did and suggesting that Loyola's law school sponsor it. He even suggested that Noonan should assume its direction. ${ }^{136}$ Wilson raised the issue with the university Trustees, all of whom were Jesuits and all of whom responded favorably to the suggestion. Wilson solicited more details from Kearney about the proposal. Kearney wrote back about two months later to inform Wilson that a Catholic Lawyers Guild of Chicago was holding an inaugural dinner. ${ }^{137}$ There was therefore no need for Loyola to sponsor the organization. Kearney suggested, however, that Loyola law students form a student group, perhaps to be called the St. Thomas More Guild, which would "combine the activities of a sodality, and those of the activities of other law schools which are commonly undertaken by law review men." He urged that

134 “Excerpts from Address of Welcome to Freshman," undated, but suggestive of a fall 1937 date attribution.

135 Supra note 106.

136 Letter from Kearney to Wilson, March 16, 1937. Kearney had joined the faculty only that year; he was listed in the law school catalog for only one year. Loyola University Bulletin, School of Law, Catalog 19361937/Announcements 1937-1938 (June, 1937), 6.

137 Letter from Kearney to Wilson, May 11, 1937. According to the website of the Catholic Lawyers Guild of Chicago, the group was founded in 1934. http://www.clgchicago.org/ See also "The Catholic Lawyers Guild of Chicago," 3 Cath. Law. 250 (1957). 
the group be both spiritual (e.g., reception of the sacraments on First Fridays) and professional (e.g., research into civil church law of Illinois).

Wilson responded promptly but coolly to the new suggestions, ${ }^{138}$ probably because they concerned an internal matter for the law school into which the president did not want to intrude. Kearney persisted for some time thereafter in a series of letters to Wilson.

In fact, a St. Thomas More club was established at the law school in early 1937, although it is not known if this was done in response to the Kearney initiative. It does not seem to have been a "sodality" of any kind; it was said to "perform the function of giving the prospective barristers an insight into the profession which they were to embrace."139 Fitzgerald, shortly before he would become the dean, helped organize the group and became its moderator. It seems to have existed for only a few years.

The dean's authority to administer the law school had not extended to faculty appointments. The dean apparently had to clear all appointments, both full-time and part-time, through the university president, primarily to monitor law school

138 Letter from Wilson to Kearney, May 14, 1937.
139 The St. Thomas More Club, The Loyolan 1937, 191. 
expenses ${ }^{140}$. Wilson soon granted Fitzgerald at least the power to sign appointment letters on his own, although it seemed that the president still had to approve the hires and the salaries. It is noteworthy the extent to which the religious affiliation of faculty candidates entered into these discussions. At this time, only Catholics continued to be hired for the full-time faculty, and the same was generally true for the part-time faculty. ${ }^{141}$ In mid-1939, Fitzgerald proposed to Wilson the hiring of two part-time teachers. Wilson accepted Fitzgerald's recommendation but commented, "To the best of my knowledge we have not discussed the religious background of these two people and while there may be exceptions, our general rule at Loyola is to engage as full time professors wherever possible members of our own church" and, since part-time teachers could later become full-time teachers, Wilson invited Fitzgerald to discuss this with him. ${ }^{142}$ Fitzgerald wrote Wilson

140 "It has been the custom for the President to make such [part-time faculty] appointments. ... I believe, however, that ... in the case of part time teachers the appointment may be made either by the President or by the dean. I am quite willing to continue the old practice or to have the deans write their letters of appointment..." Letter from Wilson to Fitzgerald, September 27, 1937.

141 “[M] ost faculty members at Catholic law schools were ... Catholic. ... [0]ne could generally expect that someone who was Catholic shared the cultural outlook of which the host university was the embodiment. ... At a minimum, a school could safely assume that a Catholic ... would not mislead students or bring the school into disrepute by teaching in a way inconsistent with Catholic beliefs." Breen and Strang, supra note 7, at 590 .

142 Letter from Wilson to Fitzgerald, May 11, 1939. 
back the next day, regretting that he had failed to state that both men were Roman Catholics. ${ }^{143}$

Another part-time appointment proved even more interesting. In this case, Fitzgerald enthusiastically recommended the hiring of the individual. He also included this cautionary note: "[The individual] is not a Catholic, but he comes from a family that I believe to have been Catholic at one time, and upon that score I have no fear that his appointment would meet the disapproval of the students, or of the faculty, or of the Regent of the School of Law."144 Wilson accepted the recommendation promptly and apparently earnestly, without any reference to the religious issue. ${ }^{145}$

The faculty meeting on March 14, 1938 was devoted to a single subject: the canon law on divorce. The minutes of the meeting elliptically state: "Questioned propriety of teaching divorce law in a Catholic law school."146 A decision on this subject was deferred, and there is nothing in the preserved record to indicate that the subject was later pursued.

Fitzgerald returned to this theme, however, in a letter to Wilson asking that the teaching load of Prof. Rooney be

143 Letter from Fitzgerald to Wilson, May 12, 1939.

144 Letter from Fitzgerald to Wilson, September 24, 1937.

145 Letter from Wilson to Fitzgerald, September 27, 1937.

146 Law Faculty Meeting, March 14, 1938. See infra note 276 for the controversial subject of divorce in a Catholic law school. 
lightened so as to allow him to devote more time to the "placement bureau" which he had been operating informally. To bolster his argument, Fitzgerald said: "We have for some time believed that the course in Domestic Relations should be taught by one well versed in the church law and attitude on divorce and annulments. Mr. Rooney so qualifies and [by relieving him of another, more burdensome, course], we think that the course in Domestic Relations would be taught in a manner compatible with the principles of a Catholic law school."147 Wilson soon accepted the concept of a placement bureau but rejected the suggestion that Rooney be relieved of any responsibilities to do so; this was prompted by its financial implications: “... [N]o emergency has arisen and I do not care to make changes in the budget if they can be avoided."148

On another curriculum matter, Fitzgerald responded enthusiastically to a letter from Wilson which passed on the suggestions of a lawyer that Loyola's law school offer its students a course in labor law. Fitzgerald wrote, "I wholeheartedly agree with his general plan, believing that the unfortunate dearth of Catholic labor lawyers is due to the

147 Letter of November 17, 1938 from Fitzgerald to Wilson.

148 Letter of November 19, 1938 from Wilson to Fitzgerald. 
failure of Catholic law schools to offer labor law courses."149 Due to the lack of available classrooms and the limited faculty, the school could not add this course to its required curriculum. Fitzgerald commented that he had instituted a "reading course" in labor law (apparently elective and perhaps not for academic credit) for the Day Division and had handled it himself, with the hope of extending it to the Evening Division the following year. Labor law, particularly in the context of Catholic social teaching, had presumably become more relevant as a result of the Great Depression.

The ABA's focus on dual division schools had not disappeared. In September 1937 Fitzgerald, who took a vigorous stance in defending Loyola and similarly-situated dual division schools, attended the annual ABA convention in Kansas City. The chairman of the ABA Section of Legal Education had noted that he found night school particularly troubling. He "doubted that even a fine night school could produce the same results as fulltime day school because of the lack of contact with its students and it would have, therefore, little influence on their professional pride and ethical standards. Part-time students

149 Letter from Fitzgerald to Wilson, February 15, 1939. 
also had the distractions of families, jobs and finances."150

The ABA's ostensible concern about the quality of legal services provided to the public belied its continued elitism since, during the Great Depression, "jobs and finances" were indeed of great concern to many aspiring lawyers.

Fitzgerald later noted that "urban evening law schools" were again (or still) in the sights of the organization. The problem, Fitzgerald told Father Wilson, "has not been settled," and the "attitude of the [ABA] on this point is not clear." He warned: "[I]f the legal profession gives way to the pressure to limit the number of those engaged in the practice of Law the 'urban evening law schools' will very probably be the first point of attack."151 Indeed, a headline in the New York Times shortly thereafter ("Law Dean attacks Part-Time Schools"152) demonstrated that the issue of evening law schools would remain controversial.

Back at home, Fitzgerald continued his efforts to insure that Loyola's academic program was as sound as possible and that its graduates were completely prepared to enter the practice as

150 Boyd, supra note 43, at 40, citing the remarks of James Grafton Rogers. Rogers was chairman from 1934 to 1937. "Chairpersons of the Section of Legal Education and Admissions to the Bar 1878-1993," in Boyd, id., at 137. He had served as Assistant Secretary of State under President Hoover in 1931-33; 34 The Colorado Lawyer, no 2 (Feb. 2005), 4, available at http://www.cobar.org/tcl/tcl_articles.cfm?articleid=4027.

151 Letter from Fitzgerald to Wilson, September 11, 1937.

152 New York Times (Feb. 20, 1938), 35, col. 1. 
competent and ethical professionals. To prove the merits of a dual division school to the ABA and driven by personal conviction, Fitzgerald and his faculty adopted a rigorous curriculum, no longer local in focus, designed to assure that every Loyola law graduate would be prepared to practice with distinction in any jurisdiction "where the Anglo-American system of law is in effect." ${ }^{153}$ The faculty, at its regular meetings, reviewed all applications to the law school, as well as reviewing the progress of all students within the school. This was part of the faculty's ongoing effort to improve the school's educational program and to assure that its graduates were thoroughly prepared for the practice of law; it may also foreshadow the Jesuit ideal of cura personalis, the concern of the institution for the individual, a concept not articulated until a later era. ${ }^{154}$

Fitzgerald and his faculty colleagues decided to embark on a transformation of the law school, building on the attention to academic quality that had emerged in recent years. This program entailed not only an increase in standards for the admission and retention of students, but also a broadening of curriculum content. "They emphasized the history and the tradition of the

153 Diamond Jubilee, supra note 71, at 5, quoting a phrase that resonated within the law school for decades.

154 Infra note 306. 
legal profession."155 In 1941, the last pre-war Bulletin carried a list entitled "Recommended General Reading." In the "Jurisprudential and Otherwise" section, the social encyclical of Pope Pius XI, Quadragesimo Anno, was listed, as was Walter Farrell's A Companion to the Summa. ${ }^{156}$ The rest of the works in that section included most of the legal realists: Brandeis, Cardozo, Holmes and Pound.

The subject of a legal clinic arose occasionally during this era, again presumably because of the Depression and the influence of Catholic social teaching. For example, at a faculty meeting in December 1938, a suggestion was made that "perhaps the law school could assist the various parish pastors in organizing informal legal clinics that they in fact now carry out by assignment of claims of indigent clients to some attorneys prominent in the parish."157 At the end of 1941 the faculty discussed the formation of a Catholic Legal Aid Clinic for the Chicago Archdiocese. ${ }^{158}$ The intervention of World War II presumably foreclosed any further discussion of this possibility

155 Diamond Jubilee, supra note 71, at 5.

156 Loyola University, Catalog 1940-1941/Announcements 1941-1942 (July 1941), at 18. The book was Walter Farrell, A Companion to the Summa (New York: Sheed \& Ward, 1938). The Summa is the Summa Theologica of Thomas Aquinas. 157 Law Faculty Meeting, December 16, 1938.

158 Law Faculty Meeting, september 23, 1941. 
During this period, the law school was required (at least by the university) to keep and report on the religious affiliations of its students. In 1931, it reported that Catholics represented 74\% of the student body, Protestants 18\% and Jews 8\%. ${ }^{159}$ In 1935 the statistics showed 78\%, 14\% and 8\%, respectively; in 1940 they were $67 \%$, 30\% and $3 \% .{ }^{160}$

In 1938 the school inaugurated graduation awards to recognize and encourage student achievement. One was named for Chief Justice Roger B. Taney in honor of the first Catholic to sit on the U.S. Supreme Court. ${ }^{161}$

It is unclear what prompted Hayes (who would later succeed Fitzgerald as dean) to put forward, at the faculty meeting on November 7, 1940, "the problem of justification of the operation of a law school under Catholic auspices."162 The faculty nonetheless voted to "take steps to collect all the available literature on the subject."163 There seems to have been no direct follow-up to this decision, presumably because of the intervention of the war.

\footnotetext{
159 "Answers to Questionnaire regarding Catholics and Non-Catholics in Attendance," supra note 102 .

160 Loyola University School of Law, "Composition of Student Body of (sic) Fall of $1940 . "$

161 By the beginning of the 21st century, however, this award was re-named the Founders Award when Taney's role as the author of the infamous decision in Dred Scott V. Sandford, 60 U.S. 393 (1857), outweighed his role as the first Catholic on the nation's highest court. 
At the start of the 1941-42 school year, the war in Europe and the beginning of conscription in the country were having a significant impact on the law school. The overwhelming majority of Loyola's law students, like those at other schools, were still male; the Depresssion-era $1930 \mathrm{~s}$ saw the number of women drop, although they never completely disappeared. Total enrollment fell that year over 26\% from the prior year (from 152 to 112), and first-year enrollment declined by 31.5\% (from 54 to $37)$.

The attack on Pearl Harbor on December 7, 1941, altered the situation dramatically. With the United States now enmeshed in a large foreign war and the need for young men to fight it, particularly when voluntary enlistments were superseded by the expansion of the 1940 draft law later that month, the future of the law school became doubtful.

The admission of new students was stopped after Pearl Harbor but classes continued for those who were already enrolled. Faculty as well as students left to contribute to the war effort. No new students were admitted for fall 1942 or thereafter. A decision was made that, when the few students who remained graduated in June 1944, the law school would suspend its operation. There was no assurance that it would ever re-open. 
As the faculty left to serve in the war effort, Rooney, the one full-time faculty member who was not entering government service and who would teach most of the courses to the remaining students, ${ }^{164}$ wrote a letter on behalf of the faculty to Joseph Egan, S.J., the university president, endorsing the decision to discontinue classes for the remainder of the war. In it, he reflected on the school's Catholic identity:

[The law faculty] had so developed our individual courses that the proper Christian philosophical and ethical principles were being taught along with the purely technical points of law. The trend of many leading law school educators in their texts and case books has been to deny the moral basis of the law. Too many instructors in American law schools have accepted the principles put forth in these texts and casebooks without question, with the result that law graduates have been indoctrinated with beliefs entirely at variance with Christian principles of jurisprudence and ethics. It is, therefore, highly important that schools which are really Catholic in their instruction prepare our Catholic lawyers for their

\footnotetext{
164 "Professor ... Rooney assumed responsibility for a large portion of the classroom teaching for the few [students] who remained." Diamond Jubilee, supra note 71, at 6. It should be noted that Sherman steele also did not enter government during the war; he had resigned for health reasons in 1942 . Supra note 93.
} 
profession. (Loyola's student body has been predominantly Catholic, usually $75 \%$ to $80 \%) \cdot{ }^{165}$

The war in Europe ended in May 1945; the war in the Pacific not until August. As the war wound down, Fitzgerald had immediately begun an effort to revive the law school. The university acceded to his pleas, and the law school reopened in September 1946 .

Through Fitzgerald's efforts, the small pre-war faculty was mostly reconstituted. The law school was given a new home in the school's newly-acquired building on Michigan Avenue, outside of the central city where it had been housed since its establishment.

In Fitzgerald's report to the alumni in November of that year, he explained why he and others insured the school's reopening:

The most compelling reason for the reopening of the School may be stated very simply. There was persuasive evidence of the worthwhileness of reopening a school whose purpose is to provide a legal education based upon the principles of the natural law.

165 Letter from Rooney to Egan, July 10, 1943. 
The School has many objectives common to all worthy law schools; it has one objective common to few: to offer to students the opportunity of studying law in an institution whose every activity is guided by the natural law. The concepts of limited state sovereignty and of inherent personal rights are not mere empty phrases to its faculty and students. ... The School ... believes that the ultimate sovereignty of God leads to freedom; that the ultimate sovereignty of man leads to slavery. ${ }^{166}$

These words not only echoed the perennial discussion within the law school community about the purpose of a legal education within a Catholic university. They also had a particular resonance for an audience that had just survived years of war and sacrifice, brought about by totalitarian governments which extolled the sovereignty of a leader over moral principles. The enormity of the Holocaust was beginning to be fully comprehended as evidence from the death camps surfaced (and the horrors of the Soviet system were yet to be fully appreciated). Fitzgerald's words presumably had a powerful impact on their readers.

166 "The Dean's Report To The Alumni" (Loyola University School of Law, November 1946). 
Fitzgerald took the opportunity of the reopening of the law school to deepen his interest in having Loyola's law school be distinctively Catholic in orientation, an interest that seems to have been burnished by his experience of the war. The "Method of Instruction and Aim" of the school, as had been articulated in the July 1938 Bulletin, ${ }^{167}$ was essentially retained in the first postwar Bulletin in April 1947. The concept of evaluating the positive law "in relation to Neo-Scholastic principles of jurisprudence" was reworked to "in relation to scholastic natural-law principles."168

In the very next Bulletin, however, that natural law idea was expanded by additional language:

The rules, standards, and principles of law are treated not as ends in themselves but as rational means to the attainment of objective justice. The School of Law, as a department of the University, is dedicated to the philosophy that there is an ideal and objective order of justice, based upon the natural law, by which human beings are endowed with certain inalienable rights and obligations, to enable them to realize in human dignity the divine destiny decreed by their Creator; that the natural

\footnotetext{
167 Supra note 133.

168 Loyola University of Chicago, Bulletin of the School of Law, Catalog 19411946/Announcements 1946-1947 (April 1947), 9.
} 
law respects and governs all human actions and therefore the actions of man in civil society which is subject to constantly changing political, social, and economic forces; that by the recognition and application of natural law to the positive civil law, human society can approach the ideal and objective order of justice intended for human beings. ${ }^{169}$

At the same time, the law school's Bulletin changed its language regarding the university itself. From at least the early 1920s, the Bulletin referred to the religious origins of the university quite simply: "The foundation ... dates back to 1870 when the Jesuit Fathers established in Chicago an institution of learning which was chartered by the state of Illinois as St. Ignatius College."170 In the first postwar Bulletin in 1947, that characterization was reworded but retained. A new paragraph was inserted with it, however, entitled "University Objectives." It provides, in part, as follows:

Loyola University, as a Catholic institution directed by Jesuits, has distinctive objectives. It seeks to integrate both general education, advanced cultural

\footnotetext{
169 Loyola University of Chicago, School of Law, Bulletin, Catalog 19471948/Announcements 1948-1949 (August 1948), 8.

170 See, for example, Loyola University School of Law, 1923-1924, 5.
} 
training, and professional excellence with the Catholic philosophy of life. Every unit of the University accordingly regards moral and religious training, thorough instruction in principles of religion and virtue, and the forming of clear and correct consciences in its students as essential educational tasks. ${ }^{171}$

It is likely that this new language discussing the university's educational philosophy was incorporated into the law school Bulletin (and those of the other University schools) on the initiative of the university, not the law school itself. It was, however, quite consistent with Fitzgerald's own philosophy. He expressed that philosophy in a story in March 1951 profiling the law school, in which he was quoted as saying: "The school realizes that by recognition and application of the natural law to the positive civil law, human society can approach the ideal and objective order intended for all human beings. " 172

It is interesting, in that context, to note Fitzgerald's 1946-47 report to James T. Hussey, S.J., the university president, in the form of a letter dated June 4, 1947. In it Fitzgerald reported, "At the present time its [the law school's]

\footnotetext{
171 Catalog 1941-1946, supra note 168, at 5.

172 Law School Merits Excellent Rating, 30 Loyola News, no. 16 (March 1, 1951), 5 .
} 
courses are substantially identical in materials, subject matter, and content with those of most American law schools."173 Probably, since he was writing to a Jesuit administrator, the natural law focus of the school was tacitly understood; what it was important to stress to the president was that Loyola's law school was comparable to other law schools in the scope and quality of its legal educational program.

The only reference to the school's Catholic identity in the dean's report to the president is in the context of what he calls "symbols":

The present quarters of the School of Law are adequate, but naked. The ninth floor of the [Michigan Avenue] Building houses a Division determined to make its weight felt in the nineteen-hundred year old controversy. Not one wall, corridor, window, or office contains any cross, picture, or quotation symbolic of that contest... It is hoped that in the near future a visitor to the ninth floor - whether applicant, stranger, alumnus or student - will be confronted with evidence of the fact that this is a Christian and a Catholic law school. May we not symbolize

\footnotetext{
173 Letter from Fitzgerald to Hussey, June 4, 1947, at 1.
} 
the legal traditions of "Bologna, Paris, and Salamanca" on our walls as well as impart them in the classroom? ${ }^{174}$

By 1950 Fitzgerald's plea for art as indicia of the

school's Catholic identity was rewarded with the dedication of a statue of Thomas More, the patron saint of lawyers, carved from solid walnut by a local artist, Patricia Watters. Presented to the school by the student Bar Association, the statue had been purchased through contributions from law students, "as a symbol of [their] fight against secularism."175

The law school had begun its second life in 1946 with a limited faculty and a limited curriculum. The initial class was composed primarily of veterans who were returning to civilian life and their careers after the interruptions of the war. To accommodate this group, the law school offered an accelerated year-round program which made it possible for them to graduate in two years.

174 Id., at 5. The unexplained mention of a nineteen-hundred controversy perhaps refers to the role of Christianity in civil society. The phrase "Bologna, Paris, and Salamanca" was a standard reference to the three oldest Catholic universities.

175 "St. Thomas More Statue Unveiled at Law School," XXIX The Loyola News, no. 23 (April 20, 1950), 6. When the law school was constructing its new home, Maguire Hall, in 1980, Watters submitted a proposal that the More statue be placed in the visible lobby of that building. She wrote, "The sculpture ... was commissioned by Loyola law students to symbolize the extra dimension a Christian lawyer should embody in the practice of the profession. This sculpture never was mere decoration; has indeed become a special symbol and "trademark' of the Loyola Law School." Patricia K. Watters, "The Saint Thomas More Sculpture," January 11, 1980, at 1. The statue was in fact placed in a prominent place in the Law Library and remains there today. 
The faculty slowly expanded as the enrollment grew. The first woman was hired to serve on the full-time faculty, ${ }^{176}$ and another soon was hired as an adjunct, although their service at the school was rather short-lived.

The university no longer appointed a regent for the school. By 1957 a reporter for an ABA site inspection team could write that "There is no priest attached to the school in its administrative or teaching force, and the dean is highly respected, as are the members of his faculty, by the priests who have governing authority over the university."177 The accreditor seemed to regard the absence of priests in the law school as an asset, since he linked it to the comment that "[t] he law school has a high degree of autonomy," suggesting that the governance of the school was in the hands of the dean and faculty. Significantly, the accreditor could also note: "All members of the faculty are Roman Catholics - they are in a sense dedicated men. This factor creates a very high faculty

\footnotetext{
176 Anne Leonard joined the faculty in the late 1940s, soon moving from a special instructor to the regular full-time faculty. She remained at the law school until 1955.

177 Gordon Johnston, Inspection Report, Loyola University of Law, Chicago, Illinois, January 14-16, 1957, 3. While the report focuses almost exclusively on matters specific to legal education, it contains a number of comments perhaps indicative of the ABA's continued discomfort, or at least unfamiliarity, with Catholic law schools. The report states: "Though the University is administered by Jesuit priests, the law school is in no narrow sense a "Parochial" school." Id. at 2 . 
morale."178 He did later state that, although all the full-time and part-time faculty members (except for one of the latter) were Roman Catholics, "there is no requirement of the school that this shall be so." ${ }^{179}$ He went on to add:

Their interest lies, however, not merely in having a good parochial school but in competing in excellence with all law schools of good standing. They have discouraged a proposed formation of an organization of Jesuit law schools, of which there are thirteen in this country. They sincerely feel that the American Bar Association and the Association of American Law Schools serve the only need that they recognize for aid in the formation of a sound pattern in legal education." ${ }^{180}$

It appears that, during this period, the faculty's focus was primarily on teaching; published scholarship was produced and was publicized, but it was apparently not a significant factor in the evaluation of the faculty. Fitzgerald himself took opportunities to promote in print his natural law philosophy. ${ }^{181}$ A number of the faculty were visible in the

\footnotetext{
178 Id. at 8 .

179 Id.

180 Id.

181 John C. Fitzgerald, The Natural Law and Social Justice, 2 Cath. Law. 137 (1956).
} 
academic, professional and social worlds through lectures and other programs.

The law school seems to have kept considerably aloof from the general university. ${ }^{182}$ As a result, the achievements of the law faculty were not always shared with the university so as to be included in university-wide faculty publications. It is therefore significant to note that, on the two recorded occasions when law school faculty participated in the university-wide lectures of the Honors Program, they both spoke on Catholic-oriented themes. Richard V. Carpenter spoke in 1955 on "The Influence of the Natural Law Doctrine on the American Constitution,"183 and Hayes spoke the following year on "Church and State: The American View."184

The course in Jurisprudence returned to the curriculum. It was offered in the summer session of 1948, when year-round schooling was required to satisfy the returning World War II

182 The law school often chafed at sharing university facilities with other schools of the university. The administration and faculty tried to retain the law school's autonomy and individuality by focusing on audiences outside the university. "The faculties of Catholic law schools were rarely willing to integrate themselves into the life and work of their universities, and these law schools were able to achieve a high degree of independence." Barkan, supra note 6, at 9. In general, information about the law school from this period is scarce. The law school seldom surrendered its records to the general university archives, and it did not generally retain them itself. There were no internal news publications specific to the law school at this time other than occasional student-produced newspapers.

183 "Honors Lectures," Loyola University Chicago, IV Staff Bulletin, no. II (Nov. 15, 1955), 8 .

184 "Honors Lecture," Loyola University Chicago, IV Staff Bulletin, no. III (Jan. 6, 1956 [mistakenly identified as “1955"]), 8. 
veterans. It remained a summer course for another year but in 1950, as the law school returned to a normal academic calendar, it was offered during the regular school year.

The law school took advantage of being part of a Jesuit university to have the course taught by a Jesuit priest. In the first few years that was P. V. Kennedy, S.J. After him, the teacher changed each year until 1952, when Paul A. Woelfl, S.J., of the university's Political science department, assumed the teaching of the course. He remained with that course for the rest of Fitzgerald's term as dean, through the 1958-59 year. In almost every year, despite the changes in teacher, the "Treatise on Law" from the Summa Theologica seemed to be one of, if not the only, required text for the course.

Jurisprudence was not the only course in which Catholic thought or doctrine played a significant role, however. For several years after the war, there was a required course (in some years, two) called "Survey" or "Special Lectures." In 1948-49, the course was described as covering "specialized fields including Canon Law of Marriage and Divorce," with patent law and securities regulation. ${ }^{185}$ The following year it included

185 Loyola University, Catalog 1947-1948/Announcements 1948-1949 (Aug. 1948), at 21. See infra note 276, for the increased interest at this time in the controversial subject of divorce in a Catholic law school. 
a section on "The Social Encyclicals and the Lawyer," ${ }^{186}$ which continued for several years.

Interestingly, there was no course in legal ethics or professional responsibility offered at this time. The Bulletin was quite explicit: "No formal group study is offered in the field of legal ethics" ${ }^{187}$ this was presumably the product of a considered decision to teach ethics pervasively throughout the curriculum rather than in a single course. There was a caution in the Bulletin, however, that the ABA Canons of Professional Ethics would be part of one question on the annual comprehensive examinations. ${ }^{188}$

With regard to the curriculum, the ABA accreditor in 1957 observed that the curriculum was completely required; there were no electives. On the other hand, he was positive in asserting that the faculty continually reviewed and updated the curriculum, adding new courses (including Jurisprudence) when appropriate, which “indicates an awareness of current trends in

\footnotetext{
186 Loyola University, Catalog 1948-1949/Announcements 1949-1950 (July 1949), at 24 .

187 Catalog 1947-1948, supra note 170, at 21.

188 "Each June, full-time students undertook more than thirty hours of examinations covering all of their course work for the year, and they received a single, comprehensive grade for that year." Thomas M. Haney, The First 100 Years: The Centennial History of Loyola University Chicago School of Law, 41 Loy.U.Chgo.L.J. 651 (2010), at 680 . 
legal education and a desire to impart legal skills and moral responsibility."189

In the fall of 1955, a 1942 alumnus of the school, Charles Strubbe, Jr., offered a program of "Great Books in Law" for law students as an optional activity for no academic credit. ${ }^{190}$ With sessions held mid-day on Tuesdays, the discussions focused on works of Plato, Aristotle, Aquinas and Machiavelli during that semester. ${ }^{191}$ The extended program included a much broader list of readings, including Thomas More's Utopia and Pope Leo XIII's encyclical Rerum Novarum. ${ }^{192}$

The 1957 reporter for the ABA could also note that "[a]t least two-thirds of the students in attendance at the school are Roman Catholics."193 In the early postwar years, the law school instituted two programs to foster the students' religious observances: a voluntary Mass at 8:45 a.m. every Friday, and a mandatory retreat each spring. ${ }^{194}$ Whether the initiative for these activities came from Fitzgerald himself or from the

\footnotetext{
189 Inspection Report, supra note 178 , at 12.

190 Strubbe was President of the Great Books Foundation until 1953, when he became the Vice-President of St. Xavier College in Chicago.

191 "Great Books in Law," October 3, 1955.

192 "The Great Books," undated.

193 Supra note 178, at 14.

194 "Catholic students in the Day Division make an annual retreat at the time appointed in the University calendar. Non-Catholic students in the Day Division attend at the same time a series of conferences on moral questions. Students of the Evening Division are invited to this retreat or these conferences." Catalog 1941-1946, supra note 169, at 16 .
} 
university, it is likely that they were accepted by the law school community.

Participation in the Friday Mass was encouraged by its location in the chapel on the $8^{\text {th }}$ floor of the Michigan Avenue building, one floor below the law school, as well as by a breakfast after the Mass in the law school lounge. The breakfast seems to have served as an opportunity for both students and faculty (who presumably attended the Mass) to gather informally for conversation. ${ }^{195}$ The Student Bar Association had a Religious Committee to plan and support such events, but there is evidence that student attendance at the Friday Mass often failed to meet expectations. ${ }^{196}$

The SBA Religious Committee also promoted the annual retreat, which was held at the university's north side campus, several miles from the law school. The committee apparently selected the priest (usually a Jesuit) who would lead the retreat each year; those chosen included the regent of the

\footnotetext{
195 There is a reference to a "faculty row" at the breakfast, with faculty discussing everything from law to baseball. "R.S.V.P. - A.M.D.G.," II Res Ipsa Loquitur, no 6 (Oct. 27, 1955), at 1 .

196 "[F] or a period of about five weeks, [the Mass] was filled to capacity," but recently had only about twenty law students. Chairman of the Religious Committee [Robert C. Hultquist], "Friday Mass," III Res Ipsa Loquitur, no. 6 (Dec. 7, 1956), at 1. Similarly, two years later there was a reference to "unfortunately a poorly attended Friday mass." Dick Wittry, "The Student Bar," V Res Ipsa Loquitur, no. 3 (Dec. 12, 1958), at 1.
} 
university's medical school, ${ }^{197}$ a priest from Marquette's dental school, 198 and one from the law school at the University of Detroit. ${ }^{199}$ As a mandatory event, there appears to have been no recorded issues about student attendance. ${ }^{200}$

While not a law school event, the school encouraged its students to participate in the Red Mass, the annual Mass in the fall for the legal community in the city, sponsored by the Catholic Lawyers Guild of Chicago. ${ }^{201}$ Here too the SBA Religious Committee promoted student participation, ${ }^{202}$ although there are recorded comments suggesting that students did not often do so. ${ }^{203}$ Poor student participation in such religious observances

197 John W. Bieri, S.J. "Retreat," III Res Ipsa Loquitur, no. 8 (Feb. 21, 1957), at 1 .

198 Willard McEvoy, S.J. "Law Retreat a Success," V Res Ipsa Loquitur, no. 5 (Mar. 22, 1959), at 6 .

199 Jerome A. Petz, S.J. "Annual Law Retreat March 1-3," VI Res Ipsa Loquitur, no. 7 (Feb. 18, 1960), at 1 .

200 By the mid to late-1950s, however, the original language about the retreat in the Bulletin ("Catholic students ... make an annual retreat") was altered to "Catholic students ... are obliged to make an annual retreat." See, for example, Loyola University, The School of Law, Catalog 1957-58/Announcements 1958-59 (August 1958), 19.

201 The Red Mass was first mentioned in the law school Bulletin in July 1949, where it was listed as a student activity; the listing contained a long discussion of the Mass's origin and meaning. Catalog 1948-1949, supra note 188, at 17. The significance of the Red Mass is discussed in "The Catholic Lawyers Guild of Chicago," supra note 137, at 252.

202 "Students of this law school should be acutely aware of the need for moral stamina and religious principles. It would behoove all of us to join the Bench and Bar of Chicago in seeking spiritual aid." "Red Mass," IV Res Ipsa Loquitur, no. 2 (Oct. 2, 1957), at 1 .

203 "[M] ore non-Catholic judges attended ... than did Loyola law students." "A Law Student Attends the Red Mass," IV Res Ipsa Loquitur, no. 3 (Oct. 16, 1957), at 2 . 
led to some disillusionment on the part of the student chair of the Religious Committee. ${ }^{204}$

The Catholic nature of the institution was emphasized even in the law school's calendar: "All holydays of the Catholic Church are celebrated as school holidays."205 Thus no classes were scheduled for the feasts of All Saints' Day, the Immaculate Conception and the Ascension, in addition to regular secular holidays.

The facilities on Michigan Avenue, which Fitzgerald in 1947 called "adequate," proved to be considerably less so, particularly as the school's enrollment increased. In 1954-55, the law school was able to move into a building a block away which had been renovated for the school. The CardinalArchbishop of Chicago, Samuel Stritch, officiated at the dedication ceremony in October $1955 .{ }^{206}$

In 1959 Fitzgerald took a two-year leave of absence to become the Deputy Court Administrator for cook County. Two

204 "As to the religious affairs of the school I will just offer my apologies for the limited activities but I am sure everyone can appreciate that, this school being a democracy - so far as religious activities are concerned there is a certain limit as to what can SUCCESSFULLY be accomplished." Bob Hultquist, "P.A.D. News," III Res Ipsa Loquitur, no. 11 (May 15, 1957), 2, at 3. (Punctuation in original) 205 Catalog 1941-1946, supra note 169, at 16.

206 "Law Building Dedication Oct. 27," Loyola University of Chicago, IV Staff Bulletin, no. I (Oct. 7, 1955), 2. His quoted remarks seem a little abstract: the school "would make profound studies in the deep underlying background of all truths to fight those who would make the state an almighty god and rob us of a hope of heaven." "Law Building Dedicated," Loyola University of Chicago, IV Staff Bulletin, no. II (Nov. 15, 1955), 2. 
years later, he stepped down from both the deanship and the faculty. 


\section{TO 1983: Transition and Growth}

The departure of Fitzgerald from the law school in 1959 initiated a period of transition in the school which had three significant consequences, although none of which could have been anticipated or appreciated at the time. First, it ushered in a period of four relatively short deanships, sandwiched between the two longest deanships in the school's history: Fitzgerald's 22 years from 1937 to 1959, and Nina Appel's 21 years from 1983 to 2004. Second, it was the last period of male Catholic deans, a tradition which had prevailed from the school's founding in 1908. Third, it was the only period in the law school's history in which the deans were all graduates of Loyola's own law school.

Despite the significant similarities, these four deanships were themselves very different. Each dean brought to the position his own perspective on legal education and on the role of Catholicism in that process. Each had to deal with specific challenges presented by the historical situation of that period, by university policies, and by other factors that came to bear on the dean's ability to achieve his goals for the school. Fitzgerald's era had been mostly one of crisis as the country endured the lingering challenges of the Depression and the Second World War, the latter of which evoked an unusual national 
unity of spirit. The postwar optimism had faded by the time that Fitzgerald stepped down from the deanship.

At the law school, the period from 1959 to 1983 was marked by rapid changes in enrollment (initially down and then up), turmoil over inadequate facilities for the school, the growth and diversification of the faculty, and the expansion of the curriculum. As a result of the spirit of individual initiative generated by events in the nation, the Church and the world, students came to play an active role in shaping the educational process and its physical setting.

\section{The Hayes years, 1959 to 1967}

John Cornelius Hayes, who was acting dean during the two years of Fitzgerald's leave, assuming the title of dean in 1961, had joined the full-time faculty soon after receiving his J.D. cum laude from Loyola in 1937. He was active in Catholic organizations throughout his life; he was elected as the President of the National Council of Catholic Men (NCCM) in 1959207, and he was a member of the Executive Committee of the National Councils of Catholic Men and Women. In 1957 he was

207 He succeeded Fitzgerald when he was elected the president of the Archdiocesan Union of Holy Name Societies in Chicago. "Mr. Hayes New Holy Name President," Loyola University of Chicago, II Staff Bulletin, no. 1 (Jan. 21, 1953), at 2. In this position he automatically became a member of the NCCM Board. He served on the Board until he became NCCM President in 1959. 
awarded the papal medal Pro Ecclesia et Pontifice by Pope Pius XII for his services to the Catholic community. ${ }^{208}$

At the start of Hayes' deanship, Loyola's law school was profiled in a short article in The Catholic Lawyer, written by a member of the full-time faculty. ${ }^{209}$ The article ascribes the law school's "origin and its continued existence" to "a need strongly felt in the legal community for a law school of the highest excellence conducted in the Jesuit tradition." ${ }^{210}$ There is no further reference in the article to the school's catholic or Jesuit identity, other than a mention of the statue of St. Thomas More. ${ }^{211}$ In a series of articles devoted exclusively to Catholic law schools, and for an audience that was likely to be primarily Catholic, there was probably little reason to articulate or explain the school's Catholic orientation in more $\operatorname{detail.}{ }^{212}$

Like Fitzgerald before him, Hayes celebrated Loyola's distinctive legal education. "It is obvious that a Catholic law

208 "Receives Honors from Pope Pius," Loyola University Chicago, VI Staff Bulletin, no. 1 (Nov. 20, 1957), at 7 .

209 Vitullo, supra note 2, at 305. According to its masthead, The Catholic Lawyer was a "quarterly magazine devoted to timely legal problems having ethical, canonical or theological implications."

210 Id.

211 Id. at 306. See supra, note 175 for the origins of the statue.

212 One scholar has criticized several of these articles for "mak[ing] almost no mention of their Catholic affiliation" or, when they did so, doing it "by referring to opportunities for prayer, reception of the sacraments, and religious retreats." John M. Breen, The Air in the Balloon: Further Notes on Catholic and Jesuit Identity in Legal Education, 43 Gonz.L.Rev. 41 (2007-08), at $47-48$. 
school must have a distinctive reason for existence over and above the functions of professional education which it shares with all other law schools."213

One of the areas in which Hayes took particular personal interest involved "obscene literature" and its relation to juvenile delinquency -- a social issue which gripped the American public at that time. ${ }^{214}$ In 1959 he organized and led a national symposium on "the case for governmental control of sexually obscene literature."215 In that specific context, he amplified his vision of the law school mission: "In Loyola's case we also exist to study, and to instruct our students in the application of natural law principles to human positive law. Consequently, we have a special interest in many legal situations with heavy moral overtones."216

213 Law School Studying Methods to Control obscene Literature in the Community, in A University and Its City, 1 The Loyola Report, no. 2 (November 1961), 18. 214 In 1957 Hayes attended the oral arguments at the U.S. Supreme court in the "consolidated obscenity cases" [probably referring to Roth V. U.S., 354 U.S. 476 (1957)] as "an observer for the National office of [sic] Decent Literature." Loyola University of Chicago, V Staff Bulletin, no. V (June 10, 1957), at 12. The National Office for Decent Literature was an organization, primarily but not exclusively Catholic, formed in 1938 to combat literature that it considered to be "a threat to moral, social and national life, especially among youth." http://archives.lib.cua.edu/ncwc.cfm\#DecentLit Hayes later commented extensively on the Roth decision in Hayes, Survey of a Decade of Decisions on the Law of Obscenity, 8 Cath.Law. 93 (1962). 215 Loyola World (Mar. 1959), at 2-3. The Archbishop of Chicago, Albert G. Meyer (not yet Cardinal), was the honorary chair of the program. The purpose of the symposium, according to Hayes, was "to achieve a definitive, professional current statement on the case for public control, with the ultimate aim of discussing this position with those who disagree..." Id. at 3 . 216 Id. 
Hayes' other interest concerned the intersecting roles and interests of the Catholic Church and the American nation. Even before he became dean, he spoke on "Church and State: The American View."217 Some of his concerns involved issues of the financial burden of parents who sent their children to Catholic schools. ${ }^{218}$ As the nation contemplated the nomination and possible election of its first Catholic as President, he articulated his views about the compatibility of Catholicism and American democracy ${ }^{219}$ - then a topic of considerable interest. ${ }^{220}$ Yet, at the same time, Hayes' assumption of the deanship brought significant changes to the faculty and the curriculum. Despite his deep personal commitment to his Catholic religion, the world, and particularly the Catholic world, was beginning to change. Angelo Roncalli was elected as Pope John XXIII in 1958. ${ }^{221}$ Shortly thereafter, the new Pope announced the Second Vatican Council, called Vatican II, which would meet from 1962

217 Supra note 184

218 Hayes, Law and the Parochial School: A Formulation of Conflicting Positions, 3 Cath.Law. 99 (1957). He spoke on "What Can We Do To Ease the Double Tax on Parents Who Wish to Give Their Children a Religious Education." Loyola World (Feb. 6, 1963), at 8. He used a local radio show to speak on "Church, State, and School." Loyola World (Jan. 1964), at 8.

219 Sees No Clash If a Catholic Wins Election, Chi. Trib., May 21, 1960, at 22. 220 John Tracy Ellis had published American Catholicism in 1956, and John Courtney Murray, S.J., had been publishing articles that were collected in We Hold These Truths: Catholic Reflections on the American Proposition (1960), both examining the role and status of the Catholic church in this country. 221 Peter Hebblethwaite, Pope John XXIII: Shepherd of the Modern World (New York: Doubleday \& Co., 1985), at 270 et seq. 
to $1965 .{ }^{222}$ The Council galvanized the Catholic world for the years of its four sessions. The discussions at and the official documents of the Council enabled the Church to restate its teachings in a way that was accessible to the modern world and which resulted in a new spirit of enthusiasm among Catholics. ${ }^{223}$ The law school's Bulletin in 1959 reflects some subtle changes. For the first time in a decade, the Red Mass was no longer categorized as a law student activity, but under the religious welfare section of "University Services to Students."224 While Catholic students were still obliged to participate in the annual retreat, there were no any longer any conferences for non-Catholic students; instead, they (like all

222 “... John XXIII, shortly after his election, was inspired to undertake the difficult and even perilous task of summoning an Ecumenical Council, the first such Council in almost one hundred years, and only the twenty-first in nearly two thousand years, according to traditional Roman Catholic reckoning." Xavier Rynne, Vatican Council II (New York: Farrar, Straus and Giroux, 1968), 23.

223 "What they [the contexts in which the Council convened] indicate is that new mind-sets had taken hold in Catholicism by the time the council opened... They suggest, therefore, that in approaching the council we should expect it to be different, expect it to have different views of the Church and the world than the ones that prevailed earlier." John W. O'Malley, S.J., Introduction, in David G. Schultenover, ed., Vatican II: Did Anything Happen? (New York, Continuum Intl. Publishing Group, 2007), 20. (Emphasis in original.) "Changes needed to be made in the Church to make it more viable in the "new era' that the council assumed was dawning." John W. O'Malley, S.J., Vatican II: Did Anything Happen?, id., 63. "[The] forces of change, which the Catholic Church had resisted for centuries, Vatican II released into the life of the Church." Neil J. Ormerod, "The Times They Are A-Changin'," id., 176. Yet all of these authors stress the element of continuity in the Council's achievements; e.g., "The charge to the Church is to hand on the message, not adulterate or change it. ... Continuity is postulated, deeper than any discontinuity, yet ... [t] he tradition is passed on only when it is rendered engaging and life-giving." O'Malley, id., 58.

224 Loyola University, Catalog 1958-1959/Announcements 1959-1960 (Aug. 1959), at 20 . 
students in the evening division), were "invited" to attend the retreat. ${ }^{225}$ In addition, the Aim and Method of Instruction section reverted to the short form used prior to World War II, ${ }^{226}$ dropping the extended language about natural law that had been added in 1948.227

William J. Kenealy, S.J., was hired as a visiting professor early in Hayes's deanship. ${ }^{228}$ Kenealy had a law degree from Georgetown and a doctorate from the Gregorian University in Rome; he was admitted to the bar in two states, the District of Columbia, and the U.S. Supreme court. After having served as a Navy chaplain during World War II, he was a leading advocate in postwar America for civil justice and desegregation. He had been dean of the Boston College Law School for fifteen years. Kenealy remained with Loyola's faculty for a few years, initially teaching Jurisprudence but after a few years concentrating on other subjects. His primary focus was on

\footnotetext{
225 Id.

226 Supra note 13.

227 Supra notes 169 and 170 .

228 He first appears in the annual catalog in 1958. Loyola University, School of Law, Catalog 1957-1958/Announcements 1958-1959 (Aug. 1958), at 8. The website of Boston College School of Law states that Kenealy taught at Loyola only from 1961 to 1963 .

http://www.bc.edu/schools/law/alumni/ebrief/features/fallo4/deansexhibit/slid e $7 \cdot h \operatorname{tml}$
} 
issues facing the nation at that time: racism and integration, capital punishment and the supreme Court's ruling on prayer. ${ }^{229}$

In 1958-59 another priest, John B. Quinn, was added to the faculty as a "special lecturer" on the canon law of marriage and divorce. ${ }^{230}$ He stayed for several years.

The following year yet another Jesuit was added to the faculty, as an adjunct teacher. Robert C. Hartnett, S.J., taught a course entitled "Philosophy of Law and of Government."231 This was probably the equivalent of the Jurisprudence course, since the books for the course included Aquinas' Treatise on Law as well as Aristotle, Cardozo and others.

The ABA returned to Loyola in 1961 for another inspection of its program. The report of the evaluators made the following reference to the law school's Catholic identity:

This school is, of course, a private school, the policies of which are substantially affected by the Catholic church and the Society of Jesus. The purpose of the school is

229 William J. Kenealy, S.J., Segregation - A Challenge to the Legal Profession, 3 Cath. Law. 37 (1957). A Jesuit Attorney and Legal Scholar Views Desegregation, The Loyola Report: The Jesuits of Loyola (undated, ca. 1960), at 22. The Supreme Court ruling on prayer probably refers Engel v. Vitale, 370 U.S. 421 (1962).

230 Loyola University, School of Law, Catalog 1957-1958, supra note 228. 231 Loyola University, School of Law, Catalog 1960-1961/Announcements 1961-1962 (Sept. 1961), 8. Hartnett taught in the university's Political Science department and was dean of the College of Arts and Sciences; see "Loyola Shapes America's Voice," in Skerrett, supra note 37, at 126. 
instruction in the law as a public service, with the constant attempt to expose the students in their study to the influences of the teachings of the Church. ${ }^{232}$

There was no suggestion in the report that the "constant attempt to expose the students ... to the influences of the teachings of the church" was in any way improper. In fact, the report praised the school's teaching: "[P]ersonal observation indicated ... that the classroom performances of several of the professors were as good as any ever heard elsewhere - very high grade, not only on the professor's parts but also by the students themselves."233 It also noted, "The quality of teaching is excellent. ... The back and forth between teacher and students seems to be education at its most effective."234

The report also applauded the faculty"s "complete autonomy as far as its educational program is concerned," 235 which was presumably a reference to the school's Catholic affiliation. The entire curriculum continued to be required; there were no electives at that time given the small size of the faculty, the student body, and the facility. The report notes a distinctive feature of this required curriculum:

\footnotetext{
232 Keeton, Gregory and Hervey, Evaluation Report, Loyola University (Chicago) School of Law, Chicago, Illinois, February 20-21, 1961, p. 4.

233 Id.

234 Id., p. 11.

235 Id., p. 6.
} 
Also there is emphasis placed on legal ethics and a course in the senior year called Philosophy of Law and of Government which all students must take. Then it must be recalled that throughout the Law School the relation between law and ethics reflected in religion is emphasized. ${ }^{236}$

This ABA accreditation report, like that in $1957,{ }^{237}$ pays particular heed to Loyola's Catholic affiliation, but neither betrays the institutional hostility to or at least suspicion of dual-division Catholic law schools noted by Fitzgerald ${ }^{238}$ and other commentators in earlier periods. ${ }^{239}$

Shortly after this time, in 1964, the law school, for the first time, added a Jesuit priest with a law degree to its regular full-time faculty: John J. Kinsella, S.J. served on the faculty for one year, went on leave, then returned in 1968 and stayed for three more years. He returned to the law school decades later as a chaplain.

In 1967, after two years of part-time teaching, William C. Cunningham, S.J. was hired to the regular full-time faculty. ${ }^{240}$

Id. , p. 13 .

Supra text at note 178 et seq.

Supra text at notes 110 et seq. (about the AALS) and 151 . Barkan, supra note 6 , at 10 .

240 Rev. William C. Cunningham, S.J., Biographical Sketches of New Faculty Members, What's Happening at Loyola University School of Law (Autumn 1967), 
In addition to his courses in constitutional law and conflicts, he would teach a course on "Selected Problems in Law and Society," which would require the students "to consider various philosophies and methods which may be relevant in the solution of these problems" and "to examine critically the philosophic basis behind existing principles of substantive law and legal remedies." ${ }^{241}$

Cunningham was an activist who represented indigent criminal defendants in state and federal courts as well as defendants across the country who were charged with violations of federal and state laws in connection with the war in Vietnam and Selective Service regulations. ${ }^{242}$ He frequently lectured on civil disobedience. ${ }^{243}$ He also concerned himself with issues of church and state. ${ }^{244}$ Cunningham remained on the faculty for several years.

3. William C. Cunningham, S.J., The Jesuits of Loyola University Chicago (1970), at 52 .

241 Loyola University Chicago, The School of Law Catalog 1964-1966, Announcements 1966/1967 (1966), 27.

242 Annual Report of the School of Law 1968 - 1969, p. 4.

243 For example, he spoke to the Holy Name Cathedral Adults' Club on "Some Reflections on Civil Disobedience" in May 1968 and, several months later, was a panelist at Valparaiso Law School on "The Law and Civil Disobedience." Loyola University of Chicago, Loyola World (May 1968), at 7-8; Loyola World (Oct. 1968), at 8 .

244 In April 1966 he spoke to the senior law class at Valparaiso Law School on "The Involuntary Blood Transfusion of the Adult Jehovah's Witness: Its Moral and Legal Aspects." Loyola University of Chicago, Loyola World (May 1966), at 14. An extended version of his remarks were later published as Indicated Blood Transfusions and the Adult Jehovah's Witness: Trial Judge's Dilemma, 2 Val.U.L.Rev. 55 (1967). 
During this period, the law school catalog described the educational program as including more than mere training in law: "[T]he School aims at alerting the consciences of its students to the fulfillment of their civil, social, and religious duties both as lawyers and as men (sic). The faculty endeavors to relate the positive law to scholastic natural-law principles and to evaluate it in the light of those principles." ${ }^{245}$

Near the end of Hayes' deanship, the law school's Bulletin underwent some changes, apparently reflecting changes within the university and perhaps in the law school. The description of the university was amplified to emphasize its Catholic identity: "A center for teaching, scholarship, service - in a setting that is Catholic, Jesuit, Urban."246 There was a discussion of what each of those three identifiers signified, although in general the descriptions seem rather bland. A Catholic University was described in the following terms:

Loyola integrates natural and supernatural truth into the general educational program. Students are motivated to "seek God in all things," so that they may find "a fuller

245 Loyola University, School of Law, Bulletin 1961-1962, 10. 246 Catalog 1964-1966, supra note 241, at 4 . 
and more fruitful life in Time, through a vision of Eternity." ${ }^{247}$

Similarly a Jesuit University is explained as follows:

Loyola is directed by members of the Society of Jesus (the Jesuits), who are world-famed educators. Assisting in the instruction and administration is a faculty of more than 1,000 lay men and women, diocesan and order priests, and nuns, who hold advanced degrees from the leading universities of United States and Europe.

The University bears the name of the founder of the Society of Jesus, St. Ignatius Loyola, a "modern educator," of the $16^{\text {th }}$ Century, who conceived a unique educational plan centering on the "whole man."248

Nonetheless, as one scholar described Loyola's law school, "by 1965 ... there were no distinctively Catholic courses listed."249 This appears to be true. There was, however, a range of offerings in ethics-related courses. No longer was there reference to not offering a course in legal ethics. ${ }^{250}$ In the 1965-66 academic year, there was a course on "Professional Responsibility and Employment Relations," ${ }^{251}$ and the following

247 Id. No source for the quotes is given.

248 Id. Again, no source was listed for the quotes.

249 Nelson, supra note 7, at 136.

250 Supra note 187.

251 Catalog 1964-1966, supra note 241, at 24 . 
year there was one on "Legal Research and Writing in areas of Professional Responsibility and the Illinois Supreme Court."252 Catholic higher education itself was beginning to change during this period. Catholics had moved beyond their immigrant status and into the mainstream of American life, confirmed by Kennedy's election as the first Catholic to be President of the nation.

In 1963 the university rescinded its long-standing policy of requiring Catholic undergraduate students to attend weekly Mass. ${ }^{253}$ Soon after, the law school's requirement of an annual retreat, and even the availability of Mass on Friday, were dropped from the Bulletin. ${ }^{254}$ The official calendar still bore the notation that there were no classes on Catholic holy days, however. 255

\title{
The Lamey years, 1967 to 1970
}

\author{
In 1967 Professor William L. Lamey became dean when Hayes \\ resigned to return to full-time teaching. Lamey, a 1939 \\ 252 Id. at 25 . \\ 253 A religious welfare committee recommended this change in March 1963; the \\ university's Board of Trustees formally adopted that proposal in July of that \\ year. "It was recognized that student complaints were not universal, but \\ that a significant few were quite articulate in their opposition [to \\ obligatory attendance at designated Masses]... . After discussion Father Bieri \\ moved and Father Biestak seconded that attendance at Mass by the students be \\ made voluntary and not of obligation. So agreed." Untitled document \\ (minutes of the meeting of the Board of Trustees), July 27, 1963. \\ 254 Catalog 1964-66, supra note 241, at 13, merely mentioning the various \\ chapels at the university. \\ 255 Id. at 32 .
}


graduate of Loyola's law school, had been recruited to the faculty from private practice when it reopened in 1946 after World War II.

In Lamey's first annual report to the university for the year 1967-78, he noted the law school's emphasis on professional responsibility: "In 1968 the School of Law celebrated the sixtieth anniversary of its founding. During that entire period the School has striven, successfully, to turn out new members of the legal profession with an abiding awareness of their professional responsibilities and with a competitively excellent legal education."256 His report the following year noted a new dimension in this context:

The last two decades, marked as they have been by the "social consciousness" explosion, have wrought considerable change in legal education in America. More than ever before, the individual lawyer's professional responsibility to society and particularly to the disadvantaged have been emphasized; and the American law schools have responded by "involving" law students and faculties more directly and personally in the development and improvement of the law

\footnotetext{
256 Annual Report of the School of Law [1967-68], p. 1 . 103
} 
and legal institutions in the interest of justice and social improvement." 257

The first and only Bulletin published during Lamey's short deanship indicates a new course in the curriculum, Legal Profession. The course description includes the lawyer's professional responsibilities, as well as other topics such as "providing for the unpopular cause or undesirable client and assuring that adequate legal services are available."258 This seems to be a manifestation of the social concerns illustrated by the activities of the Jesuit teachers, Kenealy and Cunningham, described above ${ }^{259}$, perhaps reflecting a perspective common throughout legal education at that time.

Despite the new emphasis of professional responsibility and social consciousness, however, there was no reference to Catholic social thought or the Jesuit mission, nor was there any suggestion that Loyola was doing something different from, or for a different reason than, other (non-religious) law schools. Indeed, the course in Jurisprudence or its equivalent - in fact, any course that was not strictly legal in orientation disappeared from the curriculum at this time. ${ }^{260}$

\footnotetext{
257 Annual Report, supra note 243, at 1 .

258 Loyola University of Chicago, School of Law, Bulletin 1968-1970, at 36.

259 Supra notes 229 and 242 et seq., respectively.

260 There is no mention of any such course in the Law Curriculum, Bulletin 1968-1970, supra note 258, at 30-39.
} 
Telling also were the new descriptions of the law school and the university which appeared in the Bulletin at this time. Both were broader, and their language regarding the institutions' Jesuit Catholic heritage was mildly apologetic. The university was described in only one sentence, mentioning briefly its founding by the Jesuits and its being one of the largest Catholic institutions of higher learning in the country. ${ }^{261}$ The description of the law school said the following:

Although an integral part of a Catholic university, the student body ... consists of men and women of many races and creeds. The faculty, largely laymen, is made up of members of the Protestant and Jewish faiths as well as Catholics ... dedicated to imparting ... a broad understanding of the origin, development and function of [fundamental legal principles] in a society historically structured on the Judaeo-Christian philosophy of law. ${ }^{262}$

The description does not mention that the full-time faculty at that time was still mainly, if not exclusively, Catholic; religious diversity existed principally in the large part-time faculty.

261 Bulletin 1968-1970, supra note 258, at 9. 262 Id. 
The Catholic identity of the law school was beginning to be de-emphasized, primarily in response to changes outside the law school - in legal education, in the country, in the world, and in the Catholic Church. In 1967, the presidents of some Catholic universities (not including Loyola) and other participants had issued a declaration with regard to the role of Catholic universities in the contemporary world. ${ }^{263}$ While this document had no direct influence in the law school, it probably confirmed (for some people, at least) the apparent de-emphasis of Catholicism that had been taking place in the law school and in the university. ${ }^{264}$

The Purcell years, 1970 to 1975

263 A Statement on the Nature of the Contemporary Catholic University (known as the Land $O^{\prime}$ Lakes Statement), 1967. "The Catholic University today must be a university in the full modern sense of the word, with a strong commitment to and concern for academic excellence. To perform its teaching and research functions effectively the Catholic university must have a true autonomy and academic freedom in the face of authority of whatever kind, lay or clerical, external to the academic community itself... The Catholic university participates in the total university life of our time, has the same functions as all other true universities and, in general, offers the same services to society. The Catholic university adds to the basic idea of a modern university distinctive characteristics which round out and fulfill that idea. Distinctively, then, the Catholic university must be an institution, a community of learners or a community of scholars, in which catholicism is perceptibly present and effectively operative." Par. 1. Available at http://archives.nd.edu/episodes/visitors/lol/idea.htm

264 The statement has become controversial in the Catholic Church, with some seeing it as the beginning of, and justification for, the slide of Catholic universities into secularization. Others, however, defend its insights. "A Catholic university is where the church confronts the world's different truth claims in creative dialogue. If this is true for the catholic university, it should be equally true for the Catholic law school." Sargent, supra note 9 , at 15 . 
In 1970 Professor Charles R. Purcell was chosen as dean of the law school when Lamey stepped down to return to full-time teaching. Purcell, a 1956 graduate of Loyola's law school, was then the associate dean at the University of Missouri-Kansas City law school, having previously taught at Loyola. He inherited a school that was poised on the edge of significant growth and development, with all the problems associated with those rapid changes.

Purcell expanded the faculty, including the return of women to full-time teaching. ${ }^{265}$ For the first time, the law school attempted to look beyond its own graduates and the local Catholic community for its teachers. Purcell embarked on a program to recruit faculty nationwide, so as to enhance the status of the school. In doing so, he moved to recruit promising faculty members regardless of their religious affiliation (or lack of any affiliation); being Catholic was no longer a qualification to teach at Loyola.

A larger faculty was needed as the student body, which had been shrinking under Hayes and into the Lamey years, suddenly burgeoned, in common with law schools across the country. Events in the country - the assassinations of President Kennedy,

265 Supra note 176. Among his hires was Nina S. Appel, who would later become the law school's first non-Catholic dean; supra at note 299. 
Dr. Martin Luther King Jr. and Robert Kennedy, the civil rights movement, the war in Vietnam - had at least an indirect effect on the law school, with a legal education being perceived by many as a means to effect social change. One of the most remarkable phenomena of the early 1970's was the large influx of women as law students. Loyola's law school had accepted women from the early 1920's, and women enrolled in significant numbers for a decade or so after that. When the law school was reborn after World War II, there were few women in those immediate post-war classes as the school struggled to satisfy the pent-up demand from men returning from years of military service. As women began to demand and assume new roles in society in the late $1960^{\prime} \mathrm{s}$, the enrollment of women in law schools began to increase.

As a result of the surging enrollment, the law school's building became increasingly inadequate. Much of Purcell's term as dean was occupied with student protests over their facilities. ${ }^{266}$ The university sought to solve (some would say to defer) the law school's space problems by appointing a committee for the Future of the Law School in 1974. The committee would not issue its final report recommending the construction of a

266 Haney, supra note 267 , at 696-8. 
new building for three years, by which time Purcell was no longer dean.

The law school's perception of itself may be reflected in the 1971-73 Bulletin, probably the first prepared solely by Purcell's administration. The opening section, General Information, began with a description of the university. Most of the prior description remained the same, including its founding by the Jesuits and its being one of the largest Catholic universities. It also included the lackluster statement: "The University retains its Catholic orientation."267

The section went on to describe the law school's general principles and policies, its location, its educational philosophy, and the like. The most important statement appeared to be the following: "The School has always had as its central purpose the preparation of men and women for the practice of law in any jurisdiction where the common law prevails."268 This statement was meant to signify that Loyola was not a local law school, teaching only local law, but a national institution. Tellingly, however, there is no mention of any Catholic identify or orientation whatsoever in these paragraphs. This

267 Loyola University of Chicago, School of Law, Bulletin 1971-1973, p. 8. 268 Id. This quote harkens back to the statement from the early Fitzgerald years, where the phrase "the Anglo-American system of law" was used instead of "the common law." Supra note 153. 
constituted, in the words of one later scholar, "an additional step towards secularization."269

The curriculum too reflected a moving away from any distinctly Catholic identity. Ethics remained in the curriculum, of course. The course on the Professional Responsibility of the Lawyer, begun under Lamey, was continued, although now the description made specific reference to the new ABA Code of Professional Responsibility. ${ }^{270}$

There was, however, no course offering a broader religious or even philosophical perspective on law during this time. ${ }^{271}$ Interest in social problems, reflected in the addition of courses such as Poverty Law, grew. ${ }^{272}$

Given the Catholic Church's ban on divorce and remarriage for members of the church, the subject of divorce has often been sensitive in Catholic law schools. Interestingly, in the early days of Loyola's law school, the catalogs explicitly mentioned divorce among the topics covered in the course usually called Family Law or Domestic Relations. ${ }^{273}$

269 Nelson, supra note 7, at 136. A more pessimistic view, open to question at least in terms of Loyola's experience, suggests that "American Catholic law schools did not seriously look at themselves as religious in any of these three generations [from their founding at the beginning of the $20^{\text {th }}$ century to the 1970s]." Shaffer, supra note 77, at 671.

270 Loyola University of Chicago, School of Law, Bulletin 1970-1972, at 38 .

271 Id., at 31-40. Bulletin 1971-1973, supra note 267, at 27-36.

272 Bulletin 1970-1972, supra note 270, at 37 .

273 The 1914 catalog, the first one to describe the contents of the various law courses, describes the course on "The Law of Persons and Domestic Relations" 110 
After World War II, the course was generally called simply Persons ${ }^{274}$; catalogs in that period listed only the names of courses but did not describe their content. That course name reflected the heightened attention that was focused on divorce in the Catholic legal community in that era, perhaps because of the increasing incidence in divorce in American society and thus the perilous role of the Catholic lawyer. "An attorney who takes a divorce case without sufficient cause cooperates with the state in at least one of these two evils [usurping competency with regard to divorce of Catholics since it is 'the substance of a Sacrament which is patently spiritual' and violating the divine law on the indissolubility of a valid marriage between even non-Catholics]... The attorney must obey his own conscience, not that of the client."275

as explicitly covering "[d]issolution of marriage, actions for divorce" and many other subjects. Department of Law 1914, supra note 74, at 107. The description of the optional course in Logic, Philosophy and Sociology in the early years, on the other hand, described the properties of marriage (which is "of divine institution") to include "Unity and Indissolubility; hence divorce impossible by human authority."273 The latter was an elective philosophical course offered by a Jesuit who was not a part of the law school faculty; not surprisingly, it reflected a Catholic position. The former was a purely professional subject, taught by a lawyer who was a part-time faculty member.

274 Bulletin 1947, supra note 168, at 19. No description of the course content was given.

275 Morality in Legal Practice, 4 Cath. Law. 348 (1958), at 354, 357. The very first issue of The Catholic Lawyer in 1955 carried an article on the subject: Mackenzie, The Catholic Church on Separation and Civil Divorce, 1 Cath. Law. 37 (1955). Every issue of the first volume, and a great number of subsequent issues, also focused on divorce-related subjects. The first lectures offered by the Catholic Lawyers Guild of Chicago, as early as 1944, were on "The 
In the mid-1960s, under Dean Hayes, the course name had reverted to Family Law. That catalog was the first postwar one to carry course descriptions. The Family Law course was said to cover "the formation, the continuance, and the dissolution of the family unit."276 There was only an oblique reference to "the handling of certain types of family litigation."277 There may be no reason to think that the content of the course changed, despite the change of its name, since it continued to be taught by the same teacher throughout most of this period, using a standard casebook on domestic relations. On the other hand, it is possible that, as divorce became more accepted in American culture (even among Catholics), the content of the course changed to accommodate that development. That course description continued in the law school catalogs throughout the Lamey and Purcell deanships.

\section{The Murdock years, 1975 to 1983}

In 1975, Dean Purcell stepped down from the deanship to resume full-time teaching and was replaced by Charles W. Murdock, a 1963 Loyola law graduate who was then on the law school faculty at Notre Dame. Under Murdock, the law faculty grew appreciably, and with even greater diversity. In 1976 the

Canonical Law on Civil Actions in Marriage Problems." The Catholic Lawyers Guild of Chicago, supra note 137 , at 255 .

276 Catalog 1964-66, supra note 241, at 27. 277 Id. 
law school hired its first African-American teacher when Norman C. Amaker joined the full-time faculty. Murdock also recruited a significant number of women to the faculty, many of whom would remain at Loyola for successive decades.

The Committee on the Future of the Law School issued its Final Report in 1977. The committee had examined all aspects of legal education in the United States as well as the role of Loyola's own law school in an attempt to resolve the crisis caused by inadequate facilities. The committee recommended the construction of a separate building for the law school, and the implementation of that recommendation resulted in the opening of a new law school building in 1980 .

In that context, it is somewhat surprising that the Final Report of the committee devoted considerable space to the law school's religious and value-oriented heritage; after all, the audience was the university's senior administrators who were concerned ultimately with whether the law school was worth the investment of funds necessary to secure an adequate facility for it; all of the authors as well as the intended readers were well aware of the school's Catholic affiliation. Nonetheless, the Final Report articulated clearly the law school's spiritual dimension: 
... Loyola Law School is distinctive from a secular law school in its philosophical and moral orientation and spiritual atmosphere. Respect and concern for the individual is a primary tenet of the Judaeo-Christian tradition - a cardinal characteristic of Loyola University of Chicago School of Law should be deep concern and interest in each student individually. Loyola's Law School should sponsor activities of a moral and religious character suitably related to the interests of law students and encourage an atmosphere conducive to the spiritual growth and moral development of both students and faculty ${ }^{278}$

Nonetheless, according to one later scholar, "[t]he transformation to total secularism was complete by 1978."279 Cited as evidence for this claim were the lack of anything distinctively Catholic in the school's identification of itself in the Bulletin; ${ }^{280}$ no distinctively Catholic courses being

278 Final Report of the Committee for the Future of the Law School, 1975-76, at $4-5$.

279 Nelson, supra note 7, at 136 .

280 The Bulletin carried a description of the university itself, described as Jesuit and Catholic. Loyola University of Chicago, School of Law, Bulletin 1976-1978, 9. About the law school, it said: "Although an integral part of a Catholic university, the student body ... consists of men and women of many races and creeds. The faculty, composed of laymen, is made up of members of the Catholic, Protestant and Jewish faiths." It referred to the study of law in "a society historically structured on the Judaeo-Christian philosophy." Id., at 13. Both of these descriptions had been in the law school Bulletins prior to that time. 
taught; ${ }^{281}$ and the absence of religious affiliation on the student application form, despite inquiry into the applicant's ethnic background. ${ }^{282}$ While the claim of "total secularism" was overstated, the underlying charge of a marked de-emphasis on the Catholic identity of the school was accurate.

Murdock's singular achievement of his deanship was the implementation of the committee's final report by securing university approval and funding for the construction of a building, named Maguire Hall after the former university president James F. Maguire, S.J., exclusively for the law school - the first such building in the school's existence. Unlike the dedication of the prior building in 1955, at which the CardinalArchbishop of Chicago attended the dedication to bless it, ${ }^{283}$ no such Church dignitaries attended the dedication of Maguire Hall in 1980. The current university president, Raymond C. Baumhart, S.J., was the senior religious figure presiding. ${ }^{284}$

Under Murdock, the curriculum expanded rapidly, reflecting new concerns in the practice of law and in legal education. A

\footnotetext{
281 Id. at 50-63.

282 Id. Nelson, supra note 7.

283 Supra note 206.

284 Baumhart's address seems to have contained only muted references to the school's religious heritage: "We hope to provide law students with ethical understanding and a passion for fairness. ... We also recall the Thomistic definition of law as an ordinance of reason enacted for the common good." "Maguire Hall dedicated During Ceremony on May 27," Loyola University of Chicago, Loyola World (Sept. 1980), at 1.
} 
course in Jurisprudence returned to the curriculum, but it apparently was a far cry from the earlier philosophicalreligious course offered under Fitzgerald. According to the school's catalog, the course "offers the student ... an opportunity to study the nature and elements of judicial decision-making. Suggestions from the literature of legal theory for the separation of law and morality, and rule and policy, are examined."285

The Family Law course was still said to concern "the formation, the continuance, and the dissolution of the family unit."286 Now, however, the description was greatly expanded to detail the course content. Divorce was explicitly mentioned as a topic of the course, and among the "selected issues" which might be covered were "contraception, abortion, illegitimacy" and the like. ${ }^{287}$

In 1980, a non-lawyer Jesuit, Keith J. Esenther, S.J., joined the law school as chaplain, a new position in the school. His appointment was a university, not a law school initiative. ${ }^{288}$ His role was to differ from that of the regents in the early decades of the school's existence: he was not to be a conduit to

\footnotetext{
285 Bulletin 1976-1978, supra note 280, at 57.

286 Id., at 56 .

287 Id.

288 Loyola Appoints Father Esenther Chaplain-Counselor, Loyola World (Sept. $1980), 8$.
} 
or a spokesman for the university; his sole function was to minister to the needs of law students (as well as staff and faculty), regardless of their religious affiliation, if any. Loyola responded somewhat late to the clinical legal education movement begun in the 1960's, the purpose of which was both to enable students to acquire lawyering skills under the supervision of supervising clinical faculty and to provide legal services for the poor. The law school's first clinic, the Loyola University Community Law Center (LUCLC), opened its doors in January 1981 near university's north side campus, several miles from the law school. ${ }^{289}$ While the establishment of legal clinics would not by themselves satisfy a law school's commitment to a Catholic identity, ${ }^{290}$ such clinics are nonetheless consistent with Catholic principles. At a law school with a Catholic orientation, there can be a third motivating factor: the Jesuits' preferential option for the poor. ${ }^{291}$ While the clinic was supported by Murdock and was later funded by the university, there is no indication at its founding

289 Henry Rose, A Tradition in the Making, Public Interest Law Reporter (Winter 2003), at 18 .

290 "The provision of legal services to the poor and disadvantaged undoubtedly makes a valuable contribution to a school's Jesuit identity. At the same time, however, such a contribution constitutes at best only a partial and incomplete attempt to satisfy the Jesuit demand for the promotion of justice. ... [T] he hosting of legal clinics is in no way distinctively Catholic or Jesuit." Breen, supra note 13, at 395. 291 Infra note 310. 
that the clinic was prompted by any motivations other than the traditional two, however.

A chapter of the Decalogue Society, the Jewish law students organization, was organized at Loyola in the 1980-81 school year, although Jewish students were represented in the school from at least the early 1920's, if not earlier. This appears to have been the first law student organization at Loyola with a specific religious orientation.

Confirmation of the law school's efforts to provide a distinctive legal education for its students was contained in a book published in $1981,{ }^{292}$ which evaluated legal education based on an extensive study. The authors found that Loyola law students were different from those at other law schools. They wrote:

The average Loyola graduate is significantly more likely to report instilling respect for the judicial process as a goal of the law school attended than are graduates of any other school. In addition, on two other goals, preparation for the bar examination and providing the theoretical basis of the law, Loyola graduates stand alone: they are significantly different from both the other "local" law

292 Frances Kahn Zemans and Victor G. Rosenblum, The Making of a Public Profession (Chicago: American Bar Foundation, 1981). 
schools and from all others. We think that Loyola holds a unique place among Chicago's "local" law schools and that this is reflected in the responses of its graduates. ... Whether those who select Loyola differ from those who select other local law schools, or Loyola offers a different program, or a combination of both, Loyola is a special case. ${ }^{293}$

That book, and the quote from it, was given a prominent role in a long report drafted the following year by a faculty committee for the university in preparation for the law school's $75^{\text {th }}$ anniversary in $1983 .{ }^{294}$ The introduction to that document stated that the law school "subscribes to and promotes Christian principles of individual ethics and social justice in the Jesuit tradition of rigorous scholarship and teaching."295 While there was no other reference in the 32-page document to the school's religious identity, there is no reason to believe that the authors saw Catholicism as a veneer; rather, it is equally plausible to believe that the school's religious identity set the stage for and explained the discussions of the school's significant characteristics: "a cooperative attitude [among

293 Id., at 59. (emphasis added)

294 "The School of Law, 1982 and Beyond: A Discussion Paper Prepared for the President and Senior Vice President of Loyola University of Chicago," February 1982 .

295 Id., at 1 . 
students] that is antithetical to the 'Paper Chase' mentality reflected on television," ${ }^{296}$ a concern for diversity ("minority enrollment"), 297 "special emphasis on matters of individual and social justice, ${ }^{298}$ and the like. The audience was the senior administration of the university, and the rationale for the paper was securing adequate funding for the law school; there would have been no need to articulate more clearly the religious character of the school.

Nonetheless, it must be admitted that a contemporary document addressed to an external audience, an ABA site inspection team, appeared to omit any goal related to the school's Catholic identity. ${ }^{299}$

In a comparable vein, the brief history of the law school prepared for the $75^{\text {th }}$ anniversary in $1983-84$ referred to the Catholic nature of St. Ignatius college in the context of the law school's founders seeking affiliation with it, but otherwise omitted reference to the law school's own Catholic identity. It did, however, note that the faculty, in the years prior to World

\footnotetext{
296 Id., at 13.

297 Id., at 7-9.

298 "To some extent through curriculum planning, but mainly through classroom discussion and example, the faculty has striven to promote the philosophy that law should be an instrument for securing justice, peace, freedom and human dignity in society." Id., at 2 .

299 The law school's goal was identified as: "To remain first among regional law schools and to provide a quality legal education ... to well qualified students ... at an affordable price." Inspection Report of the American Bar Association (August 23, 1978), quoted in Id., at 24. 
War I, “[b]oth by classroom teaching and personal example, ... gave life and meaning to the social, moral and ethical values implicated in the practice of the law." ${ }^{300}$

While the law school administration downplayed or even ignored the school's Catholic affiliation during this period, it is possible to discern traces of Catholic identity - either in university initiatives or in those of individual law faculty members. ${ }^{301}$

The four short deanships, from Hayes to Murdock, witnessed an increasing de-emphasis of the school's distinctively Catholic origin and traditions and clearly disclaimed any distinctively Catholic orientation in its curriculum or programs. The school's Catholic affiliation was not denied or suppressed, but neither was it proclaimed as the (or even an) identifier of its educational mission.

300 Diamond Jubilee, supra note 71, at 5.

301 For example, Professor Christine Cooper presented a paper on “The Rights of the Child - What Can an International Body of Catholic Jurists Do?" at the Pax Romana Conference of Catholic Jurists in Manila in December 1979. Loyola University of Chicago, Loyola World, Jan. 1980, at 7. Professor Cooper was elected the North American Vice President of the International Catholic Lawyers Guild at this meeting. Loyola University of Chicago, Loyola World, Apr. 1980, at 7. 151 and 


\section{3 to 2004: The Appel Years}

In 1983 Professor Nina S. Appel of the Loyola law faculty was named dean by Baumhart, the president of the university. She became not only the first woman dean in the law school's history but also its first non-Catholic and first Jewish dean. Neither her gender nor her religion seemed to matter to the university administration. ${ }^{302}$ She provided strong leadership for the law school for the ensuing two decades.

Appel reintroduced to the school a discussion of what it meant to be a law school in a Catholic setting. During the Fitzgerald and Hayes deanships, the Catholic element seemed to have been present in many ways. During the Lamey-PurcellMurdock deanships, the pendulum swung far to the other end as the school sought to position itself as a national institution, with a diverse faculty and student body, even though this entailed the muting of its Catholic identity.

Conscious of her role as the first non-Catholic dean of the school, Appel undertook to explore what legal education in a law

302 " $[\mathrm{W}]$ hen he interviewed me, Ron Walker, the then Provost to Father Baumhart, ... he said, 'I have only one question to ask you.' ... 'During the time that you are Dean, as Dean, in your official role at Loyola, do you feel it's necessary to come out for choice? Would that be an issue that you feel very strongly about in your' - and he was very careful - 'in your official capacity as Dean to lobby for?' I said, 'No. ... I think in my official capacity ... I wouldn't be lobbying for anything really.' ... That was the only question he asked me." Loyola Oral History Project - Law School, transcript of interview of Nina Appel and Thomas Haney by Maria Reynolds, Mar. 11, 2008, 18-19. (Underlining in original.) 
school with a religious affiliation was meant to encompass. Lacking the instinctive knowledge of Catholicism that prior deans (all of whom were Catholic) had possessed, she became genuinely interested in exploring the religious dimensions of the school. She was attracted by aspects of the Jesuit message such as the "preferential option for the poor"'303 and the goal of a Catholic university to educate the whole person and to treat each student individually (the Jesuit concept of cura personalis), ${ }^{304}$ which coincided with her own intention to see the law school continue to deliver a values-oriented legal education..$^{305}$

For two years in the early $1990^{\prime} \mathrm{s}$, the law school, in cooperation with the university's Center for Faith and Culture, sponsored a "Values in Law" seminar. Professor Steven Barkan of Marquette University Law School spoke on Jesuit legal education, and Professor Daniel J. Morrissey of St. Thomas University Law School spoke on "A Catholic Moment in Legal Education?"

\footnotetext{
303 Infra note 310.

304 Appel: "I have often characterized our approach as one that provides legal education on a human scale; this is influenced, of course, by our Jesuit and Catholic tradition that stresses concern for the individual and for the whole person." Mary Nowesnick, "Vision for a Vital Future," Loyola Law (Summer/Fall 1999), 8, at 9 .

305 Appel: "Loyola has always been a welcoming place for people from many faiths and racial and ethnic backgrounds, and it welcomes and nurtures people who care deeply about ethical issues and social values." Id.
} 
A letter to prospective students affirmed Appel's commitment to Jesuit goals: "The Jesuit Catholic mission of the university, to serve the 'whole individual' and to train "persons for others,' resonates within the law school" - which provided the context for her mention of service opportunities within the law school. ${ }^{306}$ This was consistent with the message conveyed by the president of Loyola, John J. Piderit, S.J., in a contemporaneous catalog of the law school, where he said: "Our cura personalis component reflects a special concern for the individual. ... So, Jesuit legal education has often been called person-centered. It is a component of our law school that is a matter of our educational philosophy; it makes Loyola University Chicago School of Law a unique experience."1307

Consistent with (but not directly motivated by) those Jesuit concerns, the law school intensified its involvement in clinical legal education. In 1984 the law school's clinic relocated to the Catholic Charities building, a central location in the city more accessible not only to law students but also to its clients. While the legal clinic was welcomed by Catholic Charities to supplement the other services it offered to the community, it appears that the law school's motive for the move

306 [Untitled], viewbook, School of Law, Loyola University Chicago, [undated, apparently 1998], no page number.

307 Loyola University Chicago, School of Law, Catalog 1993-95, 4. (Italics in original.) 
was prompted by considerations of convenience and accessibility, not by any particular desire to coordinate with the range of services offered by Catholic Charities in a religious context. ${ }^{308}$

Five other clinics, each with a specific focus, were created throughout this period. All were devoted to the twofold goals of preparing law students to be effective practitioners and providing legal assistance to persons who could not otherwise afford legal representation. While all of these ventures were consistent with Catholic perspectives, such as the preferential option for the poor, there appears to have been little or no explicit faculty discussion about this. ${ }^{309}$ Similarly, Appel set about to establish institutes and centers that would provide intensive education and training in specific areas of law, but the areas that she identified health law, children's rights (known as childlaw), elderlaw, consumer law - were those that were consistent with Loyola's Catholic religious heritage as well as urgent societal needs. The focus was on those most vulnerable members of society, as

308 Father (later Bishop) Edwin Conway, the administrator of Catholic Charities, offered space to the clinic and discussed his vision of a legal services division of its social welfare programs. While the relocation of the clinic to the Catholic Charities building was described by the clinic's director as "a marriage made in heaven," suggesting that both parties benefited from the arrangement, there is no indication that the law school viewed this arrangement as having any religious dimension. Rose, supra note 289, at $19-20$.

309 Rose, id., at 20,36 . 
expressed by the Jesuits as the "preferential option for the poor," ${ }^{310}$ a concept that Appel came to embrace. Other than that, none of the centers or institutes has emphasized any Jesuit or religious dimension of its mission and programs, focusing instead on social justice and societal needs, as well as pedagogical and research goals. ${ }^{311}$

A later development in the Institute for Health Law was the establishment of the Center for Catholic Health Care and Sponsorship. Established in 1994, the Center is dedicated to "assist[ing] Catholic health care leaders in strengthening the foundation of their ministry: sponsorship."312 Among its programs has been an annual Catholic Health Care Sponsorship conference to build expertise in women and men, many of whom were in religious orders, who were leaders in the health care field.

310 The focus on justice and on the special status of the poor have become hallmarks of Jesuit education for the past several decades. See Breen, supra note 13, at 387 et seq. These statements were featured in various Jesuit and Loyola publications throughout this period so, even though they were articulated only infrequently within the law school, there was general awareness of this new vision of Jesuit education.

311 Robert F. Drinan, S.J., the prominent Jesuit who was a professor of law at Georgetown and a U.S. Representative from Massachusetts, was the inaugural speaker at the dedication of the Civitas Childlaw Center in 1995; his talk was published as Saving Our Children: Focusing the World's Attention on the Abuse of Children in 26 Loy.U.Chi. L.J. 137 (1995). He returned as the speaker at the Center's 10th anniversary in 2003. Father Robert Drinan, 11 Civitas Childlaw Center News \& Notes, no. 5 (Mar. 2007), 1. 312

http://www.luc.edu/healthlaw/continuing_education/catholic2/current/about.htm $\underline{1}$ 
During Appel's deanship, the discussion of the school's Catholic identity added a new dimension. Unlike the situation from the 1920s to the 1960s, however, the conversation was not limited to Catholics themselves. The faculty and the student body had been expanded, and the participants in the dialogue now represented many different religious, ethical, social and cultural traditions. Appel referred to that openness to others within the context of a Jesuit-affliated law school in a letter to prospective students: "While not all of us are Catholic, the Jesuit emphasis on rigor and excellence, and above all on service to others and respect for the individual, infuses our curriculum." ${ }^{313}$

Diversity within the law school continued to expand. Loyola had undertaken to diversify its students in all respects -- gender, race, ethnicity, religion -- by the early 1920's, long before many other law schools did so and apparently in response to trends in Catholic social thought. More recent expansions of diversity for sexual orientation ${ }^{314}$ and disabilities were not accompanied by such considerations but by admissions policies prompted by influence from government and professional bodies.

313 [Untitled], viewbook, School of Law, Loyola University Chicago, [undated, apparently 1988], no page number.

314 Infra note 363 et seq. 
The oldest of the religious oriented student groups at the law school is the Decalogue society, and in recent years the law school has witnessed the formation of the Muslim Law students Association

In 1984 a Christian Fellowship Group was organized with student initiative to provide a structure for Christians (those who were not Catholic) to meet for prayer, reflection and study. The organization was superseded in 1991-92 when a chapter of the Christian Legal Society was organized at Loyola; the mission of this national organization is "to inspire, encourage, and equip Christian lawyers and law students both individually and in community to proclaim, love and serve Jesus Christ through the study and practice of law, the provision of legal assistance to the poor and needy, and the defense of the inalienable rights to life and religious freedom." ${ }^{315}$

At the same time the first student organization devoted specifically to Catholic interests was formed at the law school: a chapter of the Catholic Lawyers Guild. ${ }^{316}$ While a question was raised as to whether such an organization was needed at a

315 http://www.clsnet.org/page.aspx?pid=820

316 This was said to be the first law school in the Chicagoland area with a student chapter of the Catholic Lawyers Guild. "Chapter of Catholic Students Group Being Formed Here," 24 Blackacre, no. 3 (Nov. 26, 1991), 14. Supra note 137 for the history of the Catholic Lawyers Guild of Chicago. 
Catholic law school, 317 the students who formed the group indicated that they were seeking "a support group that would assist in spiritual development as it relates to [the students'] study of law." ${ }^{318}$ In recent years the assistant dean for student affairs, Jean Gaspardo, has undertaken the active encouragement of and involvement in this student organization.

In a reminiscence of her deanship, Appel placed Jesuit openness to those of other religions into a personal context: "I have to say that the Jesuits have been so overwhelmingly welcoming to people of other faith traditions. It just astounded me! ... And when I was Dean, I met regularly with the head of campus ministry. And we ... had and continue to have a religious person [the chaplain] affiliated with the school. ... But, again, that office is open to people of all faiths. The University leans over backwards." ${ }^{319}$

In 1988 the question of what constitutes a Catholic and Jesuit law school was explored in the lead article in the school's alumni magazine. "Does a Catholic law school have a special identity, and how does that identity influence the professional education it provides?" was the author's

317 Jim Ambrose, "Just How Catholic Are We?" 24 Blackacre, no. 3 (Nov. 26, 1991), 1, at 1 and 19, quoting a student member of the Decalogue society as saying, "It may be a little redundant."

318 "Chapter of Catholic Students Group," supra note 316.

319 Loyola Oral History Project - Law School, transcript of interview of Nina Appel, supra note 302, 19-20. (Underlining in original.) 
question. ${ }^{320}$ "These are questions that provoke much thought among Loyola's faculty and administrators, possibly because they go straight to the heart of what Loyola legal education is all about."321 Catholic alumni and faculty were interviewed for their perspectives on the issue. The title of the article, "The Jesuit Spirit: Alive, Well at Loyola's Law School," adequately conveys the author's conclusions and perhaps that the article was not intended to be truly investigative journalism, although the choice of this topic for discussion in the magazine reflects the school's continued attention to it.

Three years later, a student raised the same question explicitly but more provocatively in the law student newspaper, Blackacre. ${ }^{322}$ The article, titled "Just How Catholic Are We?," interviewed faculty, students and others about the characteristics that might distinguish legal education in a Catholic setting. The author rated Loyola's law school on various measures: high marks for a sense of professional responsibility and ethical values; a good job on diversity; "mixed reviews" on addressing relevant moral questions; and "none" about mandatory classes "to infuse in students an

\footnotetext{
320 Paul Hagland, "The Jesuit Spirit: Alive, Well at Loyola's Law School," Loyola Law (spring 1988), at 2 .

321 Id.

322 Ambrose, "Just How Catholic Are We?" supra note 317.
} 
understanding of Catholic faith and tradition." ${ }^{323}$ He concluded: "A few manifestations of the Catholic presence would not be tantamount to beating a non-Catholic over the head, or the inculcation of a parochial vision. Instead, it would serve as an indication and recognition of the strong Catholic tradition from which Loyola Law School has emerged." ${ }^{324}$ He also noted that, for the first time, a chapter of the Catholic Lawyers Guild was being formed at Loyola's law school. ${ }^{325}$

In 2002, near the end of Appel's deanship, the law school community for the first time adopted a mission statement to articulate the school's unique role; this was a prelude to a multi-year process of developing a strategic plan for the school. ${ }^{326}$ Faculty and other participants in the discussions vigorously debated how to formulate the Catholic and Jesuit dimension of the school. Eventually the following mission language was agreed on:

Loyola University Chicago School of Law is a studentfocused law center inspired by the Jesuit tradition of academic excellence, intellectual openness, and service to

\footnotetext{
323 Id. at 19.

324 Id.

325 Id. A separate article in the same issue discussed the chapter formation in more detail. "Chapter of Catholic Students Group," supra note 316 , at 14. 326 "Loyola ... recently finished a process of three years of meetings to arrive at a strategic plan; discussions of Jesuit mission were an important part of this process and of the plan adopted." Alan Raphael, Affirmative Action and Admissions at Jesuit Law Schools, 36 Loy.U.Chi.L.J. 587 (2005).
} 
others. Our mission is to educate diverse, talented students to be responsible leaders in a rapidly changing, interdependent world, to prepare graduates who will be ethical advocates for justice and the rule of law, and to contribute to a deeper understanding of law and legal institutions through a commitment to research, scholarship and public service. ${ }^{327}$

Subsequent to adopting the mission statement, the faculty continued to work for a long period to translate that general vision into concrete goals and objectives. Among the eight goals that were eventually adopted was one to "advance the Jesuit tradition of social justice and ethics in law and integrate it into law school life" (goal 2). The goal to "assure a curriculum that prepares Loyola students to be accomplished and ethical leaders" in the profession and the larger community (goal 5) was accompanied by an objective to integrate and emphasize social justice and ethics issues in the curriculum (objective 2 of goal 5). The goal to increase the school's visibility (goal 8) was accompanied by an objective to "identify and communicate the law school's strengths and unique identity, including its Jesuit-inspired tradition of academic

327 http://www.luc.edu/law/about/mission.html The mission statement was adopted by the law faculty in 2002 . 
excellence and commitment to social justice" (objective 1 of goal 8). ${ }^{328}$ No regular process was established to assess the law school's success in achieving these goals and objectives, although they remain in the background on law school policymaking •

During this period, the law school significantly enhanced its status as a nation-wide institution. Attention to the national market for faculty and students deepened the school's commitment to a national (and international) perspective. At the same time, the elective curriculum continued to expand dramatically, often in connection with the school's centers and institutes. It also came to include subjects that were unique to a Jesuit Catholic law school. Some of these courses, which include the following, became a regular part of the curriculum:

- Religion and the Law, taught by Philip J. Grib, S.J. of the full-time faculty;

- Jurisprudence: The Catholic Social Tradition, taught by John Breen of the full-time faculty;

- Canon Law for Civil Lawyers, taught by a priest (later bishop), Thomas Paprocki, and later for a few years by a nun, Sister Margaret Mary Rodde, O.S.F., both members of

328 The goals are available at: http://luc.edu/law/faculty/goals.pdf. The objectives are available at: http://luc.edu/law/faculty/objectives.pdf. 133 
the part-time faculty with significant credentials in canon law;

- Law, Life and Jesuit Spirituality, taught by John Costello, S.J., a Special Assistant to the President of Loyola. The course on Jurisprudence continued to be offered. Other courses, not unique to Catholic law schools but perhaps with special significance there, also appeared. These included Church and State, ${ }^{329}$ Law and Literature (touching on "the relations between the just and the divine"), Law and Poverty, Bioethics and the Law, 330 "The Law of Death and Dying," Feminist Jurisprudence, Law and Sexuality, Introduction to Islamic Law, and International Human Rights. ${ }^{331}$

Jesuit priests played a role in the life of the law school from its beginnings. In the latter half of the 20 th century, several Jesuits with law degrees became members of the full-time faculty: Kinsella, Cunningham and Kenealy. Kinsella returned to the law school in 1983, at the start of Appel's deanship, solely as a chaplain; he used his position not only to say Mass ${ }^{332}$ and

329 This course was initially taught by a priest, Francis J. Powers, C.S.V. It was later taught by Kinsella and others.

330 One of the many teachers of the course over the years was William Grogan, a Chicago priest and a graduate of the law school.

331 In one year this course was taught by a Jesuit, Russell Powell, S.J. Loyola Law, Spring/Summer 2002, 3.

332 At this period, as throughout most of the last several decades, the chaplain said Mass (or provided for it) for law students throughout each exam period, but not regularly throughout the school year. Since the law school is located in the heart of Chicago, a short distance from the city's Catholic 134 
to minister to the students but also to help acquaint the entire law school community with his perception of the role of Catholicism in legal education. ${ }^{33}$ Grib initially joined the law school as a part-time teacher and chaplain, but in 1987 he joined the full-time faculty, ${ }^{334}$ where he remained for almost a decade.

Esenther, the chaplain who joined the law school at the end of the Murdock deanship, left that position in 1983 for another assignment but returned in 1992 to replace the ailing Kinsella. ${ }^{335}$ The chaplain had become an integral part of the law school community as a counselor, not just for Catholics, but for students, faculty and staff from all backgrounds. When Esenther later left again, the position was continued, held first by Bro. James Zullo, F.S.C., and then by the current chaplain, T. Jerome Overbeck, S.J. The chaplain's role is to make the law school experience more balanced and more humane -- an example of Loyola's concern for the individual. Recognizing the strain that having one spouse in law school can place on a marriage,

cathedral, law students always had easy access to Catholic services. Law students and faculty have also participated in the university's Mass of the Holy Spirit at the beginning of each academic year, as well as the law school's own Baccalaureate Mass before each year's graduation.

333 Paul Hagland, “Kinsella: Teacher, Scholar, Counsel," Loyola Law, spring 1988,5 .

334 Paul Hagland, “Grib: A Greater Presence in Class," Loyola Law, spring 1988, 5 .

335 Two New Chaplains Replace Fr. Kinsella, 24 Blackacre, no. 5 (Apr. 2, 1992), 16. Esenther was joined for a while by Charles O'Byrne, S.J., who was a graduate of the law school of Columbia University. 
the chaplains have organized annual programs for married couples, called variously "Staying Best Friends" or "Married Life and Law School."

Throughout her deanship, Appel was sensitive to the Catholic dimension of the law school. She understood the sensitive nature of "hot button" topics within Catholicism -divorce, abortion, ${ }^{336}$ homosexuality, and the like. To deal with student involvement in those areas, she delegated much of the process to the associate dean for student affairs at that time, James J. Faught, who as an experienced administrator, a graduate of the law school and a Catholic, was well equipped to work with students to achieve their goals while avoiding unnecessary conflict with Catholic doctrine. This effort was enhanced by the reciprocal understanding of the Jesuit presidents from time to time, who seemed to appreciate the sensitive handling of those issues within the school.

Law Students for Life was a student group formed in 1986 over a concern with "America's growing apathy towards those who cannot defend themselves - namely the unborn, the terminally ill, the poor, and the elderly." ${ }^{337}$ This group became the ProLife Society in 1994-95, one of the years in which the group was

336 Supra note 302 .

337 "Cardinal to speak at Loyola Law School This February," 24 Blackacre, no. 3 (Nov. 26, 1991), 7. The group was described as "a non-denominational organization with many non-Catholic members." Id. 
particularly active. Like most student organizations, the level of activity in any year was a function of its membership at that time. During its active years it sponsored several lectures and programs on unborn children and on the right to die.

Other students decided to form an organization to explore similar issues from a pro-choice perspective. This development raised concerns for a Catholic law school: on the one hand, a law school is a perfect institution for the full discussion of a full range of considerations regarding legal issues in society but, on the other hand, as an institution with a Catholic identity, it did not want to allow the advocacy of positions that were contrary to the teachings of the Catholic church. A group, tentatively called Students for Reproductive Rights, formed in 1992. Soon after its organizational meeting, the university denied registration to a similar undergraduate group, stating, "Loyola encourages open debate ... but as a Catholic institution, it 'will not register a group whose primary purpose is the support of abortion as a morally acceptable choice." "338 The law student group then indicated that its "primary purpose is not advocating legalized abortion. The organization will deal with HIV infection, cocaine babies and many other 338 'Pro-Choice' Club Likely to be Rejected, 24 Blackacre, no. 5 (Apr. 2, 1992), 1. See also James J. Faught, An Approach to Dealing with Controversial Student Organizations, 78 Marq.L.Rev. 313 (1995), at 318 et seq. 
issues."339 Eventually the Reproductive Issues Society became a registered student group in 1993-94.

Each student group was allowed to advocate for its position within the law school. Under the oversight of Faught, each group had to confine its focus to the legal aspects of their respective sides, and each had to approach the other group's arguments with civility. ${ }^{340}$ A spirited debate ensued in the student newspaper at the end of the 1991-92 academic year, with proponents of both right to life and pro-choice positions arguing vigorously the merits of the issue. ${ }^{341}$ It appears that the controversial nature of the topic resulted in some students attempting to disrupt the ability of one group (often the prolife group) to publicize its activities. ${ }^{342}$

339 Abortion Rights Group Willing to Compromise, 24 Blackacre, no. 6 (May 1, $1992), 3$.

340 Faught, supra note 338, at 317. This approach was critiqued in John J. Fitzgerald, Today Catholic Law Schools in Theory and Practice: Are We Preserving Our Identity?," 15 Notre Dame J.L.Ethics \& Pub.Pol'y. 245 (2001), at $262-4$.

341 Richard Craig, 'Pro-Choice': A Study in Avoidance, 24 Blackacre, no. 5 (Apr. 2, 1992), 11. Warren J. Hazelton, Where's the Humanity in Right to Life?, id. at 10. The following issue of the newspaper included letters to the editor, with the caveat that it printed all the letters that it received, had solicited none, and did not endorse or reject any of the viewpoints represented. Letters, 24 Blackacre, no. 6 (May 1, 1992), 4. 342 A letter to the editor in the student newspaper in 1986 complained about posted signs of Loyola Law Students for Life having been wrongfully removed. Robert Reeb, Letters to the Editor, 19 Blackacre, no. 1 (Sept. 16, 1986), 10. Five years later, the problem apparently recurred. "There has been a recent increase in this problem, especially connected with the opponents and proponents of abortion." Father John Kinsella, S.J., "On Apostles, Slavery and Posting Signs," 24 Blackacre, no. 1 (Sept. 19, 1991), 6, at 8 . The matter continued throughout that academic year: "[M] aterial is regularly torn down [from the Loyola Law Student for Life bulletin board], apparently by those who advocate a different point of view." Pro-Life club Reports Board 
Law Students for Life invited Cardinal Joseph Bernardin, the Catholic archbishop of Chicago, to speak at the law school in 1992. ${ }^{343}$ Bernardin had articulated a philosophy of "the consistent ethic of life," which brought together various strands of Catholic social thought from the death penalty to abortion. ${ }^{344}$ This position had great appeal to a wide range of audiences and served to bring persons of disparate views together in rational dialogue.

An incident involving abortion during Appel's deanship arose in 1996 when the Newsbrief of the law school's Career Services office carried a job listing for the National Organization for Women (NOW) ${ }^{345}$ The notice sought students to work unpaid over the summer on the NOW V. Scheidler case, 346 which was a nationwide class action based on the federal anti-

Vandalized, 24 Blackacre, no. 5 (Apr. 2, 1992), 15. Faught explained that this was a violation of the code of student Conduct. Id.

343 "Cardinal to Speak," supra note 337.

344 "The 'Consistent Ethic' is Bernardin's moral vision of life issues based on two principles regarding the sacredness of human life - the obligation to protect and nurture it, and not to bring direct harm to it. Bernardin believes that this concept provides a framework for moral analysis across the full spectrum of pro-life concerns." Mary Hallan, Bernardin Calls for a 'Consistent Ethic,' 24 Blackacre, no. 5 (Apr. 2, 1992), 1. "Surprisingly, Loyola Law Students for Life did not approach Bernardin because of his status as the Archbishop of Chicago... [Quoting the group's president, student Richard Craig,] 'It was Bernardin's committment [sic] to the pro-life movement that prompted us to invite him to speak - not his religious convictions." Cardinal to Speak, supra note 337. 345 Loyola University Chicago School of Law, Office of Career Services, Newsbrief, Jan. 1996, at 2 . 346765 F.Supp. 937 (N.D. Ill. 1991), 968 F.2d 612 ( $7^{\text {th }}$ Cir. 1992), 510 U.S. 249 (1994), in which the supreme court had remanded the case to the federal court in Chicago. 
racketeering statute (RICO) against Joseph Scheidler, the head of the Pro-Life Action League ("League") and others who opposed NOW's advocacy on behalf of abortion rights. The notice, which was carried intact from the text that had been received from Now, referred to the defendants at "anti-choice terrorists."347

The notice was seen not only by students and graduates, the intended audience, but by others as well. Letters were directed to the dean and to the president of the university, both protesting and supporting the posting of the employment notice. More significantly, the notice was called to the attention of Scheidler by a Loyola law graduate. ${ }^{348}$ It provoked a demand by the League for an apology, a promise that "such a thing would not happen again," and a request for students to volunteer to work on the pro-life side of the case. ${ }^{349}$ The law school did not respond directly to scheidler or the League at that time. As a result, when scheidler and other pro-life activists gathered in

\footnotetext{
347 Newsbrief, supra note 345.

348 "Scheidler was stunned when the ad was brought to his attention by his attorney ... who was alerted by Mary Hallan, director of the Respect Life office for the Archdiocese of Chicago. Ms. Hallan is a graduate of Loyola's law school." League Protests at Loyola Law School, Pro-Life Action League, Action News, Apr. 1996, at 6. Hallan was later appointed the first woman and the first non-cleric associate chancellor of the Catholic Archdiocese of Chicago by Bernardin's successor as Cardinal-Archbishop of Chicago, Francis George. Hallan Makes History, Loyola Law (Spring/Summer 1998), 21. 349 League Protests, supra note 348 .
} 
Chicago in early April prior to the Democratic National Convention, they vowed to protest against Loyola. ${ }^{350}$

About a week later, the League organized a public protest outside the law school. ${ }^{351}$ For a day or two, the group protested outside the law school with graphic signs illustrating the evils of abortion. ${ }^{352}$

The law school administration's response was distributed in two forms. First, there was a long memo from Faught to the faculty, staff and students. This memo read in part as follows: Our policy in the Career Services office is to accept announcements of all lawful professional employment for attorneys and law students. Not surprisingly, this is the policy for the other Jesuit law schools as well... ${ }^{353}$

This policy is both prudent and fair ... because we cannot withhold lawful employment from our students, or discriminate against employers with whom we disagree, even if our disagreement is about fundamental principles. ...[L] awyers have a professional responsibility, within their

\footnotetext{
350 "'We'll be at the abortion mills, we'll be at some newspapers that will not run pro-life ads,' and Loyola University Law School." Maureen O'Donnell, Abortion Foes Warm Up for Convention, Chi. Sun-Times, Apr. 2, 1996, at 9. 351 Rogers Worthington, Abortion Protester Calls Loyola University a Traitor, Chi. Trib., Apr. 8, 1996, at 2C1.

352 "Large posters of the aborted babies were displayed..." League Protests, supra note 348 .

353 This statement was based on a telephone survey of the policies of other Jesuit law schools. "Survey of Job Posting Policies," undated and unsigned.
} 
own moral code, to represent unpopular parties and causes, within the law.

At Loyola, we try to train our students to understand fully the arguments on both sides of any legal issue, and we encourage them to work to change laws which they consider to be unjust. In order to be an effective advocate one must have a full grasp of the "best" legal arguments to be made on an issue. ${ }^{354}$

The second response took the form of a letter signed jointly by Appel and the university president, apparently distributed to those who had written about the issue, and others. This long letter contained the following statements: At issue is the law school's obligation to provide career information for students, versus the University's Catholic commitment to protecting the rights of the unborn. As you might imagine, this is an extremely complex balance. Loyola University Chicago has never wavered from its uncompromising support for the rights of unborn children. We do not advocate abortion. ... We do not provide abortion counseling to our students. In fact, there is no

354 Memo from James J. Faught, Associate Dean for Student Affairs, to Faculty, Staff, and Students, Mar. 26, 1996. 
university-sponsored class or service that advocates abortion as an alternative to unwanted pregnancy.

On the other hand, our law school is obligated to provide its students with a comprehensive educational experience. ... This is an obligation unique to university law schools which, if properly educating its students, must free them to explore all facets of the important legal issues facing society today; even if a particular facet of a given issue is in direct opposition to the beliefs of the university

The obligation to properly train law students is not and cannot be fairly characterized - as an endorsement of any particular issue or activity.

We understand that this is an extremely complex and sensitive issue that cuts to the heart of what Loyola University Chicago represents. We also value your faith that we would never betray our Catholic heritage. ${ }^{355}$ The debate over pro-life and pro-choice issues was to return to the law school almost a decade later, under Appel's successor..$^{356}$

355 Letter from Father John J. Piderit, S.J., President, and Nina S. Appel, J.D., Dean, undated [apparently April 1996], at 1-2. 356 Infra at note 372 . 
An issue that might have also engendered concern in some Catholic quarters, but which did not do so, is the role of lesbian and gay students in the law school. In the early 1990s, the university's nondiscrimination policy, carried in the law school's catalogs, explicitly expanded to include sexual orientation. ${ }^{357}$ In November 1994, after the National Coming Out Day, a law student published an article in Blackacre, the student newspaper, affirming that he was gay. ${ }^{358}$ The author made no reference to Loyola's being a Catholic law school. There is no record of any reaction to the article.

About 2000, a student group coalesced; initially known as the Loyola Lambdas, it concerned itself with issues pertaining to lesbian and gay legal matters. As with the pro-life and prochoice student groups, Faught enforced a policy of civility and the limiting of advocacy to legal issues. ${ }^{359}$ The group changed its name to the Gay-Straight Alliance in 2005 and, in the following year, it became outLaw, a name which the group continues to use.

In retrospect, Appel's deanship was characterized by a renewed attention to the role of religion in the law school and

357 Catalog 1993-95, supra note 310, at 2. The prior catalog, 1991-93, did not include this category.

358 Richard Sul, “Come Out, Come Out, Where Ever You Are," 16 [sic] Blackacre, no. 3 (Nov. 18, 1994), at 5.

359 Loyola University Chicago School of Law, Code of Conduct, available at http://www.luc.edu/law/academics/rules/pdfs/code.pdf 
its Catholic identity. Forums were provided at which issues with significant moral implications could be raised and explored within the school. Prospective students were explicitly informed of the school's religious heritage and its Jesuit affiliation and its implications. ${ }^{360}$ The school's traditional emphasis on public service, professionalism and professional ethics was enhanced. ${ }^{361}$ The subject of justice was explicitly

360 Throughout this period, the law school hosted a number of lectures and programs in which the Catholic identity of the law school was prominent. In February 2001 the Law Journal began to sponsor an annual conference; the topic for the very first year was law and religion. In 2002, the annual Unity in Diversity Week activities included a talk on "Catholicism and the Legal Practice." Loyola University Chicago School of Law, Loyola Bulletin, Mar. $15,2002,1$.

361 Appel made it a particular focus of her deanship to insure that every student was acquainted with the complete range of lawyers' professional responsibility. For example, the Public Interest Covocation, begun in 1989 , is an annual event at which lawyers are recognized for their full-time or pro bono activities in helping the underrepresented, to insure that the students not only appreciate the problem of the underrepresented but also the various ways in which lawyers can contribute to addressing that problem.

Throughout her deanship, Appel vigorously promoted the importance of public service to the students. As students' indebtedness at graduation skyrocketed due to increasing tuition and limited financial aid, she agonized over the seeming inconsistency of educating students about public service and then seeing those students graduate while burdened with large loans to repay. "It is a bit hypocritical for deans to say to a student who may have a \$60,000 debt and family dependents, 'I would like you to enter public interest work," Boyd, supra note 43, at 135. The law school was able to establish the Loan Repayment Assistance Program (LRAP) to ameliorate this situation modestly by grants to recent graduates who pursue careers in public service. Easing the Way into Public Service Law, Loyola Law, Fall 2006 , at 4 .

Concurrent with the administration's focus on public interest, students took the initiative to establish the Public Interest Law Society (PILS) in 1988-89 and the Public Interest Law Review in 1995-96. PILS is one of the most active student groups, its most notable achievement each year being the PILS Auction, which raises funds to support law students in unpaid summer jobs in the public interest area. 
raised on occasion. ${ }^{362}$ Unlike earlier eras, these discussions were not completely within a Catholic context. Just as Catholics had been absorbed into the mainstream of U.S. society over the course of the $20^{\text {th }}$ century, so too had the broader society been incorporated into the life and culture of the law school.

Appel believed that the question of what it means to be a law school in a Catholic university was one that needed to be raised and debated continually, even knowing that there was no one right and complete answer, that the faculty and the students would have different opinions, and that each generation would approach and respond to the question differently.

362 For example, a panel discussion on “Law and Justice: Are They Still Connected?" was organized by Zullo, the chaplain, in April 1997. According to one of the panelists, a student complained that "this was the first time in any of her classes that she could recall any meaningful discussion of justice." Breen, supra note 13, at 383. It is impossible to say how much explicit discussion of justice has occurred in classrooms over the years. It is likely that most discussions of related topics such as legal ethics, public service and professionalism, both in the classroom and in public lectures and programs, have occurred in the context of justice. The Loyola law faculty chose justice as the focus for the collection of their articles which was published in 36 Loy.U.L.J. (2005) at 329 et seq. 


\section{Into the New Century}

Appel stepped down in 2004 and became Dean Emerita. Diane Geraghty of the faculty served as the interim dean for one year. She was succeeded the next year by David Yellen, formerly the dean of Hofstra Law School. Like Appel, Yellen is Jewish. While it is too soon to have sufficient perspective to offer a serious assessment of the school's Catholic identity in the current era, a few preliminary observations may be made.

Two of the most significant religion-related events in the past few years have occurred as the result of university, not law school, initiatives. First, in 2009 the university's new John Courtney Murray, S.J. Chair was awarded to Robert John Araujo, S.J., who was then given a faculty appointment in the School of Law, returning a Jesuit to the full-time faculty. ${ }^{363}$

In 2010, the law school received a grant from a trustee of the university, a lawyer but not a graduate of Loyola's law school, to create a program on Law and Religion. ${ }^{364}$ The goal of

363 The chair was named for Murray, "a Jesuit priest and theologian who was known for his efforts to reconcile Catholicism and religious pluralism." Legal Leader Takes Loyola Chair, Loyola Magazine (Winter 2009), 25. See also Robert John Araujo, S.J., John Courtney Murray, S.J.: A Citizen of Two Cities (the Inaugural Lecture of the John Courtney Murray Chair), 42 Loy.U. L.J. I (2010).

364 Gift Establishes Religion and Law Program, Loyola University Chicago School of Law, 2010-11 Dean's Annual Report, 48. "“Loyola is an ideal location for this type of program,' [donor Barry McCabe] says. '... Loyola embraces a set of Jesuit, Catholic values and not only tolerates other value systems, but 
the new program is "to explore the rich and complex relationship between law and the three Abrahamic Faiths: Judaism, Christianity and Islam. ... The Program will facilitate an interdisciplinary and interfaith dialogue on the mutually informing influence of theology, religious traditions, and the law...." ${ }^{365}$ An executive director of the program was selected to supervise its initiatives, ${ }^{366}$ including the initial lecture series in the spring of 2012 .

A public dialogue about the role of Catholicism in legal education has not disappeared from the law school. The school hosted a panel discussion on "A Jesuit Law School - What's the Difference?" in April 2009. The three speakers, and the moderator, articulated their own visions of what a Catholic legal education might include. ${ }^{367}$

In 2010 the annual full-day faculty retreat included a session on the Jesuit identity of the university and its implications for the law school, which consisted of a presentation by the assistant to the university president for

actually embraces and encourages them." Where Religion Meets Law, Loyola Law (Fall 2010), 16, at 17.

365 http://www.luc.edu/law/academics/special/center/religion_programs.html

366 Director of New Law and Religion Program Named, Loyola Law, Fall $2011,2$. 367 Jerry Crimmins, Catholic Law Schools Face Challenge: Profs," Chgo. Daily Law Bull, Apr. 24, 2009, at 3. The speakers were Mary Ann Glendon of Harvard, Thomas C. Kohler of Boston College, and Vincent D. Rougeau of Notre Dame, and the moderator was John M. Breen of the Loyola faculty. 
mission and identity. The goal of his office is to "provide opportunities for the Loyola community to engage with our mission" and "to deepen their understanding of our Jesuit Catholic tradition and explore our heritage of 'educating the whole person.'"368 A vigorous and frank faculty discussion followed the presentation.

Sensitive topics have also been explored. The Law Journal's annual conference in 2005 concerned issues in death and dying, and the following year it focused on same-sex relationships. In early 2010, the school offered an informal discussion on abortion, at which two members of the full-time faculty ${ }^{369}$ offered their own perspectives on this controversial topic. At the beginning of the 2010-11 school year, Professor Helen Alvaré370 spoke to faculty and students on "Health Care Reform and the Future of Religious Institutional Players." None of these events provoked any significant controversy. Controversy was stirred in 2004, however, when the law school's alumni association decided to bestow its annual st.

\footnotetext{
368 http://www.luc.edu/mission/

369 John M. Breen and Christine G. Cooper.

370 A law professor at George Mason University School of Law, Alvaré had worked with the National Conference of Catholic Bishops for many years, in a variety of capacities, and she had "assisted the Holy see on matters concerning women, marriage and the family, and respect for human life." http://www.law.gmu.edu/faculty/directory/fulltime/alvare_helen
} 
Robert Bellarmine award $^{371}$ on Lisa M. Madigan, a 1994 graduate of the school who was the first woman to be elected Attorney General of the state of Illinois. Despite her reputation as an outstanding attorney general, ${ }^{372}$ she had engendered antipathy among some by her strong support for women's freedom of choice and for gay rights. The announcement of her being chosen to receive the award provoked considerable protest from some quarters, particularly the pro-life movement. ${ }^{373}$ The president of the university, Michael J. Garanzini, S.J., declined to intervene in the controversy, despite the alleged request of Cardinal George, to do so. ${ }^{374}$ Despite concerns about security ${ }^{375}$, the alumni association proceeded with the award. It seems safe to conclude that, in the current era, there is concern for and interest in the law school's Catholic tradition and heritage within the school, but that the concern and interest are often generated by individual faculty members,

371 Named after St. Robert Bellarmine, a Jesuit theologian, the award was established by the law alumni association in 1985 to honor graduates who had been in practice for 15 years or less.

372 For example, she received the John F. Kennedy New Frontier Award in 2005, presented annually to "exceptional young Americans under the age of 40 whose contributions in elective office ... demonstrate the impact and value of public service in the spirit of ... Kennedy." http://www.jfklibrary.org/Events-andAwards/New-Frontier-Award/Recipients/Lisa-Madigan-2005.aspx?t=2.

373 See, for example, Matt C. Abbott, The Death Culture at Loyola University Chicago, available at www.renewamerica.com/columns/abbott/050701.

374 Ibid. See also Madigan Honored at Loyola Chicago, WWw.freerepublic.com/focus/f-religion/1266363/posts.

375 "John Jansen led a protest ... situated such that everyone who attended the formal dinner had to see our graphic abortion signs and placards." Joe Scheidler, Picketing Loyola Law Award, in Pro-Life Action Fights Back, 19982005, http://prolifeaction.org/about/news/2006v25n3/history3.htm. 
by the university, and by others outside the institutional structure of the school. Publications of the school, in print and online, contain few references to the school's Catholic identity. The curriculum continues to offer elective courses with a Catholic or religious focus ${ }^{376}$ but no new courses have appeared with that perspective. Justice, public service and professional ethics remain in their respected positions within the school, and new initiatives have been established in these areas. ${ }^{377}$

376 See text prior to note 329 , supra.

377 Health Justice Project Expands Its Reach, Loyola Law, spring $2012,16$. 151 


\section{Conclusion}

Reviewing the history of the law school for the past century, it is possible to make some judgments about the roles that Catholicism has played during that span of time. There is no doubt but that the Catholic identity of the school has survived through many different historical eras, manifesting itself uniquely in each.

For much of the school's first years, the administration and faculty of the law school were content to provide a professional legal education for a mostly Catholic, mostly immigrant or first generation American, population; whatever religious influence existed was provided by the university.

During the 1920s, the law school became imbued with Catholic social thought, but this focus was primarily a product of a university representative, not the law school itself.

The mid-1930s to the mid-1960s may have been a "golden age" of Catholic legal education at Loyola. In any event, it is evident that the administration and faculty of the law school together devoted themselves consciously to incorporating Catholic principles into almost all aspects of the school. Natural law, as a counterbalance to positive law, was stressed, and this emphasis was no mere veneer: it was heralded in materials prepared for various external audiences, whether 
potential students or alumni or professional organizations, as well as in internal materials, such as minutes of faculty meetings and letters and reports to the university administration.

The next two decades brought an inexorable slide into secularization, a period in which the school's Catholic heritage was distinctly muted.

The following two decades saw the re-introduction of the Catholic heritage as an appropriate subject for exploration, discussion and implementation in various forms. This was by no means a consistent theme of the administration, but there is also no doubt but that the subject of religion was again a valid topic of conversation and discussion within the school.

Judgment on the last several years of the $20^{\text {th }}$ century and the beginning of the current century is premature at this time. In reviewing the record of the past century, it is possible to draw a few conclusions. First, how one interprets Loyola's history in regard to its relationship with Catholicism is dependent, in great part, on what one considers to be a true "Catholic law school." In the introduction to this article, I indicated various criteria that have been proposed by scholars and commentators for the past century to determine just what constitutes a "Catholic law school." One can select any one of 
those criteria, or any combination of them, trace its impact and expression through Loyola's history, and draw the appropriate conclusions from that analysis. Since the starting point of the analysis is the criteria to be used, any conclusions will necessarily follow from that. It is therefore possible, and even likely, that readers will draw different conclusions from an examination of the same historical record by using different criteria to evaluate the school.

Second, the Catholic identity of Loyola's law school has never been fixed; it has varied from time to time. These shifts have resulted from several influences: the perspective of the particular dean; the initiatives (or lack of them) on the part of the university administration; the status of the Catholic community in the United States and in particular in Chicago, having grown from a church serving a mostly immigrant community, to one with a community composed of a wide diversity of adherents, and from a church with communicants who were willing to let the hierarchy and clergy be the main actors to one where the Catholic population is increasingly willing to assert new roles for women and men in the church; the status of the Catholic religion in the U.S., progressing from a body perceived to be alien to one which fully partakes of U.S. culture (for better or worse); and many others. Thus, even applying a 
consistent standard or set of criteria as to what constitutes a true "Catholic law school," the conclusions drawn from such an analysis would be dependent upon the era in which one was examining the historical record.

Third, every faculty member, administrator, staff person and student over the past century will have had a different experience and will have received a different impression of the influence of the Catholic religion in the life of the law school, depending in part on their own situation and their own perspectives. Any individual story therefore may well differ from the institutional history conveyed in this article. Some may have experienced a deeply religious atmosphere at the law school during their years there, which they may consider very positive or very negative. At the same time, some others, even contemporaries of the first group, may have perceived no religious atmosphere, which again the individual may consider very positive or very negative.

Fourth, it is not always clear what the origin of any religion-related initiatives at the law school may have been. The law school does not exist as a stand-alone entity. It is governed not only by the law school administration and faculty, but also by the university. It is subject to federal and state laws and regulations. It must comply with membership 
obligations of organizations evaluating legal education such as the ABA and the AALS, as well as organizations governing admissions, career services, and other activities and services. The legal profession too, as potential employers of the school's graduates, has exerted a direct or indirect influence over some of the school's decisions. Loyola's alumni are frequently involved in the ongoing life of the law school and are willing to offer thoughts for the school's improvement. All of these external groups have, from time to time, developed standards, criteria and suggestions which the law school is obliged to consider and perhaps implement. It is likely that some of the decisions discussed in this article are the product of such external forces.

Finally, it must be acknowledged that the historical record is not complete. For example, it was only in some eras that minutes of faculty meetings were not only taken but transcribed. Communications between the law school and the university were done by letter in earlier times, and many of these have survived; the modern era of voicemail and email results in fewer hard-copy documents for the archivist and the historian to examine. Items such as the annual catalog and the student newspaper were traditionally printed and distributed; they are now made available online, in electronic versions. Nonetheless, 156 
it is probably safe to conclude that, even should additional troves of documents about the law school come to light, they would add nuance to the story and would perhaps alter some details, but the overall picture would remain the same. In summary, it is probably safe to say that the law school is and perhaps never was not all that a "Catholic law school" could or should be. On the other hand, it is misleading to suggest that Loyola's legal education is or has been indistinguishable from that of non-Catholic institutions. ${ }^{378}$ Loyola has offered and continues to offer courses, services, programs and other activities which mark it as distinctively Catholic. How successful that makes the school in achieving its potential to take full advantage of its Catholic heritage depends again in great part on one's own definition of what a Catholic law school should be. Regardless of one's perspective, however, it cannot be denied that the school's status as part of a Jesuit Catholic institution of higher education has been and remains one of its principal identifiers.

378 "Jesuit law schools show relatively little objective evidence of their religious affiliation. For the most part, Jesuit law schools, and most Catholic law schools, for that matter, are virtually indistinguishable from their secular counterparts." Barkan, supra note 6, at 9. "[T]oday's typical Catholic law school is indistinguishable from its secular counterparts." Nelson, supra note 7, at 127. "Today, most - if not all - Catholic law schools have largely succeeded in making themselves indistinct." Uddo, supra note 7, at 34. "[T] he intellectual life of these institutions ... is indistinguishable from that of their secular peers." Breen and Strang, supra note 7 , at 555 . 


\begin{abstract}
History is never ending; it is continuous. Loyola's law school has begun its second century of existence. The school, and therefore the role of Catholicism in that school, will continue to change and develop throughout time. Whatever conclusions one draws from looking at the record of the past will offer little guidance for the future. That future will be created by the women and men who will study, teach, administer and serve the law school in coming years.
\end{abstract}

Professor, Loyola University Chicago School of Law. I particularly want to thank Kathy Young, Loyola University Chicago's archivist, and her staff; her diligent efforts and willingness to cooperate contributed greatly to my ability to complete this article. All of the internal Loyola publications and documents cited in this article were obtained from the university archives or are in the personal collection of the author. 